\author{
Universidade de São Paulo \\ Faculdade de Economia, Administração e Contabilidade \\ Instituto de Pesquisa Econômica
}

\title{
Distribuição de Renda e Demanda Agregada no Brasil (1995-2013): Uma Análise a partir de Extensões aos Modelos neo-Kaleckianos
}

Júlia Burle Gonçalves

Orientador: Laura Barbosa de Carvalho

São Paulo

2017 
Prof. Dr. Marco Antonio Zago Reitor da Universidade de São Paulo

Prof. Dr. Adalberto Américo Fischmann

Diretor da Faculdade de Economia, Administração e Contabilidade

Prof. Dr. Eduardo Amaral Haddad

Chefe do Departamento de Economia

Prof. Dr. Ariaster Baumgratz Chimeli

Coordenador do Programa de Pós-Graduação em Economia 
Júlia Burle Gonçalves

\section{Distribuição de Renda e Demanda Agregada no Brasil (1995-2013): Uma Análise a partir de Extensões aos Modelos neo-Kaleckianos}

Dissertação apresentada ao Departamento de Economia da Faculdade de Economia, Administração e Contabilidade da Universidade de São Paulo como requisito parcial para a obtenção do título de Mestre em Ciências.

Versão Corrigida

(versão original disponível na Faculdade de Economia, Administração e Contabilidade)

São Paulo 
FICHA CATALOGRÁFICA

Elaborada pela Seção de Processamento Técnico do SBD/FEA/USP

Gonçalves, Júlia Burle

Distribuição de renda e demanda agregada no Brasil (1995-2013)

uma análise a partir de extensões aos modelos neo-kaleckianos / Júlia Burle Gonçalves. - São Paulo, 2017.

$97 \mathrm{p}$.

Dissertação (Mestrado) - Universidade de São Paulo, 2017.

Orientador: Laura Carvalho.

1. Desenvolvimento econômico 2. Economia keynesiana 3. Distribuição de renda 4. Macroeconomia I. Universidade de São Paulo. Faculdade de Economia, Administração e Contabilidade. II. Título.

CDD -338.9 
Este trabalho é dedicado a minha mãe, Marília, a meu pai, Roberto, e a meu irmão, Artur. 


\section{Agradecimentos}

Agradeço aos meus professores, desde a graduação na Universidade de Brasília até o mestrado, que me introduziram às ciências econômicas sob um olhar crítico e instigador. $\mathrm{Na}$ UnB, em especial à professora Maria de Lourdes Rollemberg Mollo, cuja orientação me despertou a motivação para o ingresso no mestrado. Na Universidade de São Paulo, ao professor Gilberto Tadeu Lima pelos ensinamentos em sala de aula, pela motivação, pelos conselhos profissionais, e por todas as contribuições ao desenvolvimento deste trabalho. Também ao professor Fernando Rugitsky por ter colaborado para o progresso deste trabalho com comentários e reflexões.

Agradeço aos meus pais, que me propiciaram a melhor educação que eu poderia ter e que tanto me apoiaram emocionalmente e financeiramente durante o mestrado. Pai, quem tem matemática tem a vida? Obrigada por despertar em nós o fascínio pelas ciências exatas, pela cobrança leve e despretensiosa e por vibrar comigo qualquer resultado de prova, exame, teste, por menor que fosse. Mãe, minha afinidade com a área acadêmica não veio à toa. Acompanhá-la desde criança conciliando trabalho, filhos, mestrado e depois doutorado me fascinou, orgulhou e inspirou a almejar as mesmas coisas. Agradeço também aos meus irmãos e maiores parceiros, Artur, Fernanda e Tiago, por todo o carinho e companheirismo.

A mudança de cidade com o mestrado poderia ter sido dura, mas com tantas visitas frequentes e queridas, nunca pude sentir a distância. Obrigada a todos familiares e amigos que a cada visita trazem um pedaço de Brasília a São Paulo.

Agradeço enormemente aos amigos que fiz no mestrado. FFV, o suporte, o apoio e a companhia que compartilhamos tornou esses dois anos mais que memoráveis e especiais. Guardarei com muito carinho os nossos momentos de estudo, salinha e boemia. Aos colegas do grupo de orientação, obrigada pelas discussões sempre frutíferas e interessantes, e pelas inúmeras contribuições ao andamento deste trabalho. À minha roomie, Lulus, obrigada pelo aconchego paraense, companheirismo e paciência. Aos amigos de Brasília, companheiros de vida, que vibram comigo todas as vitórias e que estiveram junto em tantos momentos importantes, tenho a certeza que seguimos juntos; obrigada por tudo.

Por fim, agradeço especialmente à minha orientadora, Laura Carvalho, que tanto admiro e que me orientou com afinco. Acompanhou de perto todo o desenvolvimento deste trabalho, sempre contribuindo com questionamentos e interpretações novas. Contribuiu também para o meu amadurecimento acadêmico e profissional, ao me incentivar a participar de congressos, ao me aconselhar sobre carreiras, doutorado e trabalho, sempre com compreensão e paciência. Muito obrigada, Laura! 


\section{Resumo}

O arcabouço teórico neo-Kaleckiano parte da importância da demanda efetiva no processo de geração de renda para relacionar sua distribuição funcional parcela da renda destinada a salários e lucros - à demanda agregada, e assim caracterizar o tipo de regime de demanda das economias, se wage-led (parcela de salários a afetando positivamente) ou profit-led (parcela de lucros a afetando positivamente). Contribuições posteriores propõem extensões ao modelo convencional que incluem o efeito de economia aberta, do crédito, e da distribuição pessoal da renda sobre o tipo de regime característico. Partindo de tal arcabouço e da trajetória da Economia Brasileira nos anos 2000, esta dissertação busca avaliar empírica e teoricamente a relação entre distribuição funcional, distribuição intrasalarial e endividamento das famílias. No âmbito teórico, um modelo neo-Kaleckiano que avalia relação dinâmica de longo prazo entre dívida e distribuição é desenvolvido. No âmbito empírico, a relação entre distribuição funcional e demanda efetiva para economia brasileira no período 1995 a 2013 é analisada, mas considerando o impacto de variáveis ausentes do modelo seminal, que foram abordadas no modelo teórico apresentado, e que parecem relevantes para explicar o desempenho da economia brasileira no período - crédito, distribuição intrasalarial e preço das commodities. Resultados sugerem que o controle para estas variáveis de fato alteram o efeito da distribuição funcional sobre a demanda agregada e vice versa.

Palavras-chaves: modelo neo-Kaleckiano, regime de demanda, economia brasileira, endividamento, distribuição pessoal. 


\section{Abstract}

The neo-Kaleckian theoretical framework focuses on the importance of effective demand in the income generation process in order to relate its functional distribution - share of income that goes to wage and profits - to aggregate demand, and thus characterize the demand regime that leads it, either wage-led (wage share positively affecting demand or profit led (profit share positively affecting demand). Recent contributions include extensions to the standard model such as the open economy effect, household debt, and personal distribution of income to further characterize the regime type. Departing from that approach and from Brazilian Economy's performance on the 2000s, this thesis aims to empirically e theorethically analyze the relationship between functional distribution, wage distribution and household debt. In the theorethical ground, a neo-Kaleckian model in which long term relationships between wage heterogeneity and household debt is developed and analysed. In the empirical ground, the relationship between functional distribution of income and aggregate demand is analyzed for the Brazilian Economy in the period 1995-2013, but testing whether variables that are not present in the seminal model that seem to affect the brazillian economy in the 2000s - household debt, personal distribution of income and commodity prices - alter the relationship between the two variables. Our results suggest that the control for those aspects indeed change the intercept and inclination of our demmand and distributive curves.

Key-words: neo-Kaleckian model, demand regimes, brazilian economy, household debt, personal distribution of income. 


\section{Sumário}

Introdução . . . . . . . . . . . . . . . . . . . 13

1 Literatura neo-Kaleckiana . . . . . . . . . . . . . . . . . . 17

1.1 Modelo Kaleckiano Canônico . . . . . . . . . . . . . . . . . . . . 17

1.2 Desenvolvimento da literatura . . . . . . . . . . . . . . . . . . . 19

1.3 Ciclos distributivos . . . . . . . . . . . . . . . . . . . . 20

1.4 Economia aberta . . . . . . . . . . . . . . . . . . 23

1.5 Distribuição Pessoal . . . . . . . . . . . . . . . . . . . . 24

1.6 Endividamento . . . . . . . . . . . . . . . . . . 26

1.7 Estudos empíricos . . . . . . . . . . . . . . . . . . . . . 31

1.7.1 Críticas aos estudos empíricos . . . . . . . . . . . . . 34

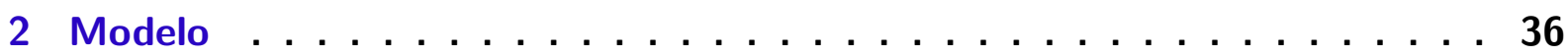

2.1 Motivação . . . . . . . . . . . . . . . . . . . . . 36

2.2 Consistência entre fluxos e estoques . . . . . . . . . . . . . . . 38

2.3 Produção e firmas . . . . . . . . . . . . . . . . . . . . . . 39

2.3.1 Consumo dos ricos versus pobres . . . . . . . . . . . . . . . 41

2.4 Equilíbrio no Curto Prazo . . . . . . . . . . . . . . . . . . . . 43

2.5 Médio prazo . . . . . . . . . . . . . . . . . 47

2.5.1 Dinâmica de médio prazo da dívida . . . . . . . . . . . . . . . 47

2.5.2 Dinâmica de médio prazo da distribuição da renda . . . . . . . . . . . . 48

2.5 .3 Equilíbrio . . . . . . . . . . . . . . . . 50

2.6 Considerações finais . . . . . . . . . . . . . . . . . . . . . . . 55

3 Economia Brasileira e Econometria . . . . . . . . . . . . . . . . . . 58

3.1 Introdução . . . . . . . . . . . . . . . . . . . . . . . . . 58

3.2 Economia Brasileira . . . . . . . . . . . . . . . . . . 60

3.2.1 Boom no preço das commodities e Investimento . . . . . . . . . . . 60

3.2.2 Políticas distributivas e consumo . . . . . . . . . . . . . . . 61

3.2.3 Endividamento e o consumo . . . . . . . . . . . . . . . 64

3.3 Dados . . . . . . . . . . . . . . . . . . . . 65

3.3 .1 Distribuição funcional anual . . . . . . . . . . . . . . . . . 65

3.3 .2 Distribuição funcional trimestral . . . . . . . . . . . . . . . . 68

3.3.3 Distribuição intrasalarial da renda . . . . . . . . . . . . . . . . . . 71

3.4 Método VAR e a inclusão de variáveis exógenas . . . . . . . . . . . . . . 73

3.5 Exercício Econométrico e Resultados . . . . . . . . . . . . . . . . . . . . . 74 
3.6 Considerações finais . . . . . . . . . . . . . . . . . . 82

Conclusão . . . . . . . . . . . . . . . . . . . . 84

APÊNDICE A Análise de estabilidade do modelo . . . . . . . . . . 87

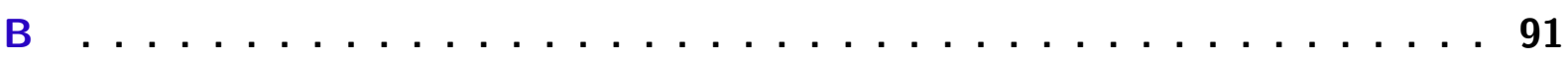

Referências ........................... 92 


\section{Lista de ilustrações}

Figura 1 - Curva de demanda efetiva vs. Curva distributiva . . . . . . . . . . . 22

Figura $2-$ Curva $d=0 \ldots \ldots \ldots \ldots \ldots$

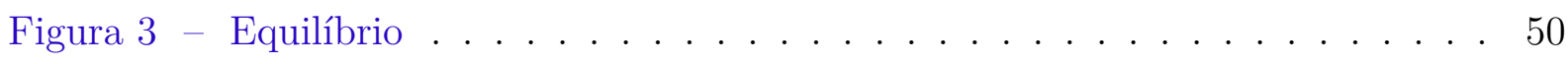

Figura 4 - Choque positivo em $\phi \ldots \ldots \ldots \ldots \ldots$

Figura 5 - Choque negativo em $\phi \ldots \ldots \ldots \ldots \ldots$

Figura 6 - Choque em $\beta$ : caso $1 \ldots \ldots \ldots \ldots 4$

Figura 7 - Choque em $\beta$ : caso $2 \ldots \ldots \ldots \ldots$

Figura 8 - Evolução do preço das commodities . . . . . . . . . . . . . 60

Figura 9 - Distribuição funcional vs. distribuição intrasalarial . . . . . . . . . . . 62

Figura 10 -Operações de crédito do sistema financeiro a pessoas físicas/PIB . . . . 64

Figura 11 - Parcela de Salário: Ingênuo vs. Ajuste 1 . . . . . . . . . . . . 67

Figura 12 -Denton Aditivo: Desvios em nível (h0) vs. primeira diferença (h1) . . . 69

Figura 13 -Denton Proporcional: Desvios em nível (h0) vs. primeira diferença (h1) 70

Figura 14 -Desagregação própria vs. Bastos $(2012)$. . . . . . . . . . . . . 70

Figura 15 -Índice de Gini para salários: comparação . . . . . . . . . . . . . . . . . 71

Figura 16 -Índice de Gini para salários: encadeamento das duas séries . . . . . . . 72

Figura 17 -Índice de Gini para salários - série trimestral . . . . . . . . . . . . 73

Figura 18 -Séries utilizadas nas estimações . . . . . . . . . . . . . . . 74

Figura 19 -Flutuações na distribuição funcional e no grau de utilização . . . . . . 75

Figura 20 - Função Impulso Resposta da NUCI a choques na parcela de salários . . 78

Figura 21 - Função Impulso Resposta acumulada da NUCI a choques na parcela salarial . . . . . . . . . . . . . . . . . . . 79

Figura 22 - Função Impulso Resposta da Parcela de Salários a Choques na NUCI . 80

Figura 23 - Função Impulso Resposta acumulada da parcela salarial a choques na

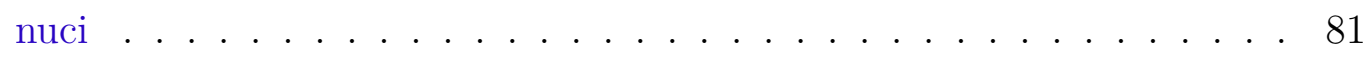




\section{Lista de tabelas}

Tabela 1 - Matriz de Transação . . . . . . . . . . . . . . . . . . . . . . 39

Tabela 2 - Derivadas de $\omega_{r}$ e $\omega_{p} \ldots \ldots \ldots \ldots \ldots$. . . . . . . . . 40

Tabela 3 - Derivadas parciais de $u^{*}$ no equilíbrio . . . . . . . . . . . . 45

Tabela $4-$ Dados ........................... 66

Tabela 5 - Coeficientes dos VARs . . . . . . . . . . . . . 77

Tabela 6 - Testes de Raiz Unitária . . . . . . . . . . . . . . . . . . . . . 91

Tabela 7 - Granger Causality Test . . . . . . . . . . . . . . 91 


\section{Introdução}

A distribuição de renda e sua relação com o crescimento econômico é antigo objeto de estudo da economia. Evidências de "Capital in the 21st Century" de Piketty (2014) mostram que a redução da desigualdade em países avançados entre 1910 e 1970 é interrompida a partir da década de 1980, quando começa a ser observada concentração de renda persistente até o presente momento. Esta tendência se manifesta tanto na concentração no topo da distribuição de salários, como na divisão da renda entre salários e lucros. Piketty (2014) atribui tal fenômeno à diferença entre taxas de retorno do capital e taxa de crescimento econômico, às quais associa políticas econômicas implementadas, especialmente no âmbito financeiro e tributário. O estudo traz a relação entre distribuição de renda e crescimento de volta aos holofotes do debate macroeconômico e instiga novas pesquisas na área.

Economistas clássicos como Smith, Ricardo e Marx já apresentavam suas explicações para a divisão da renda entre trabalhadores e proprietários do capital e da renda. Para estes teóricos, a oferta de trabalho é perfeitamente elástica, a distribuição de renda é determinada de forma exógena, segundo as condições de subsistência dos trabalhadores e todo o excedente além da remuneração do trabalho é destinado ao lucro. Em abordagens neoclássicas, a distribuição está associada à produtividade marginal dos fatores de produção - capital e trabalho -, portanto também determinada exogenamente.

Dentre os teóricos ${ }^{1}$ que partem do princípio da demanda efetiva, segundo o qual condições de demanda agregada determinam o produto, e o emprego dos fatores de produção não segue a lógica neoclássica, a questão distributiva também é importante para o processo de geração de renda. Keynes (1937) aponta a importância da distribuição de renda e riqueza na determinação da propensão média a consumir da economia, cujo potencial em deprimir o consumo contribui para a incapacidade intrínseca das economias de atingirem o pleno emprego. Em Kalecki (1942), o aspecto distributivo é a essência da análise: a propensão marginal a consumir dos lucros é inferior à dos salários e, portanto, a distribuição entre as classes econômicas influencia diretamente o consumo o investimento. Para o teórico, a repartição da renda é um fenômeno microeconômico associado ao processo de formação de preço: o grau de monopólio da economia, representado pelo mark up sobre os custos unitários da produção, define o nível de preços e por conseguinte a distribuição funcional da renda de maneira exógena.

A literatura pós-Keynesiana busca combinar hipóteses clássicas sobre distribuição da renda exógena com o princípio da demanda efetiva defendido por Keynes e Kalecki,

$1 \quad$ Principalmente Keynes (1937) e Kalecki (1942). 
para analisar questões como demanda, crescimento, distribuição e ciclos econômicos em um cenário de subutilização da capacidade. Dentro deste grupo, em especial os modelos neo-Kaleckianos se concentram nos efeitos de alterações na distribuição funcional da renda - salários e lucros - sobre a demanda agregada e representam o principal arcabouço teórico dentro da tradição pós-Keynesiana para a análise de crescimento liderado pela demanda. Estes modelos desenvolvidos seminalmente em Rowthorn (1981), Dutt (1984), Taylor (1985) e Bhaduri e Marglin (1990) combinam: (i) a hipótese Kaleckiana de que a propensão a poupar ${ }^{2}$ é diferente entre trabalhadores e capitalistas (ii) equações de formação de preço por mark-up e (iii) funções de investimento independentes. Definem países como wage-led, quando o aumento da parcela de salários afeta a demanda agregada positivamente e profit-led caso contrário. (Lavoie (2014))

Contribuições recentes destes modelos incluem extensões com o objetivo de destacar outros fatores que influenciam demanda e distribuição, entre eles, o efeito de economia aberta (Blecker (2011), Lavoie e Stockhammer (2012)), da distribuição pessoal da renda (Dutt (1992), Tavani e Vasudevan (2014), Carvalho e Rezai (2015)) e do endividamento das famílias (Dutt (2006), Barba e Pivetti (2009), Setterfield e Kim (2016)). O modelo canônico também inspira uma série de trabalhos empíricos (e. g. Stockhammer Engelbert e Stefan (2009) , Onaran e Galanis (2012), Barbosa-Filho e Taylor (2006), Bowles e Boyer (1995)), cujo objetivo é investigar o impacto de mudanças na distribuição funcional sobre o grau de utilização da capacidade e assim classificar economias de países como wage-led ou profit-led.

Neste contexto, o desempenho de algumas economias latino-americanas nos anos 2000, nas quais coexistem, por pelo menos algum período de tempo, crescimento econômico e melhora distributiva, em contraposição à tendência mundial de concentração, é interessante objeto de estudo empírico. Desde década de 1990 até o final dos anos 2000, é notório o processo de redução da desigualdade de renda em alguns países da América Latina $^{3}$, conforme ressaltam Lustig, Lopez-Calva e Ortiz-Juarez (2013). São dois os fatores que explicam tal fenômeno alinhado ao crescimento expressivo: a alta demanda mundial por produtos exportados pela região, que funciona como um choque externo positivo, e políticas domésticas de estímulo à demanda e distributivas.

No caso brasileiro, os anos do governo Lula são marcados por políticas sociais de transferência de renda, de aumento das taxas reais de crescimento do salário mínimo, de aumento de gastos em saúde, educação e infra-estrutura, e outras que facilitaram o acesso das famílias ao crédito, que juntas resultaram na intensificação do consumo em massa e

$2 \quad$ Hipótese também discutida e analisada em Kaldor (1955).

3 Lustig, Lopez-Calva e Ortiz-Juarez (2013) encontram que o coeficiente de Gini se reduz de forma estatisticamente significante em 13 dos 17 países latino-americanos. Em estudo mais aprofundado para os casos de Brasil, México e Argentina, eles atribuem tal declínio a dois fatores: transferências governamentais mais progressivas e queda no prêmio para mão de obra qualificada. 
no aumento de investimento público e privado. Tais políticas aparentam ter surtido efeito positivo sobre o nível de emprego da economia, reduzido a desigualdade da renda, e sido capazes de gerar crescimento econômico via expansão da demanda agregada (Serrano e Summa (2012)).

Este processo, entretanto, é interrompido nos quatro anos subsequentes ao primeiro mandato do governo Dilma, culminando na recessão econômica atualmente vivida pelo país. Além da piora no cenário externo, mudanças no rumo das políticas macroeconômicas internas contribuíram para tal desaceleração. Deve-se também considerar os desafios estruturais decorrentes do modelo de crescimento econômico com melhora distributiva, levando-se em conta as particularidades por trás, conforme ressaltam Carvalho e Rugitsky (2015). Entre elas a expansão do consumo baseado no endividamento das famílias, os desdobramentos de mudanças na estrutura produtiva que a distribuição a favor da base da pirâmide acarreta, e a dependência de um mercado internacional aquecido para as exportações nacionais.

A partir da experiência brasileira e do arcabouço teórico Kaleckiano, esta dissertação de mestrado tem como objetivo analisar teórica e empiricamente a relação entre demanda efetiva e distribuição funcional da renda.

No âmbito teórico, o objetivo é abordar a relação entre duas variáveis que tiveram impacto sobre a trajetória da economia brasileira nos anos 2000 e que já foram modeladas dentro da literatura Kaleckiana como extensões: o endividamento das famílias e a dispersão salarial. Estes fatores foram tratados de diversas maneiras neste arcabouço inclusive conjuntamente em modelos que abordam o consumo conspícuo. Entretanto, não há registros de modelo que avalie a relação dinâmica entre distribuição funcional e endividamento em um contexto econômico no qual a distribuição intrasalarial da renda também é relevante para indicar o grau de concentração da economia, que é justamente o objetivo do aqui desenvolvido. Esta estrutura econômica parece apropriada para analisar a dinâmica da dívida das famílias em economias de natureza distintas. No Brasil, por exemplo, a discrepância salarial não é desprezível e de certa forma restringe o acesso ao crédito das famílias da base da pirâmide. Em economias desenvolvidas, apesar de não ser limitadora do acesso ao crédito, a dispersão salarial e a intensificação da concentração no topo nas últimas décadas também são regra e não exceção. Portanto, independentemente do tipo de economia, parece evidente que considerações sobre outras formas de desigualdade além da funcional são essenciais ao se analisar a dinâmica da dívida.

No âmbito empírico, o objetivo é avaliar econometricamente a relação entre distribuição funcional da renda e demanda efetiva para a economia brasileira entre 1995 e 2013. O propósito não é definir o regime de demanda do Brasil, mas tentar identificar como aspectos ausentes do modelo básico que já existem como extensões também estariam influenciando a relação entre as duas variáveis. São estes aspectos o endivida- 
mento das famílias e a distribuição intrasalarial explorados no modelo teórico, e o efeito de economia aberta, que também contribuiu para o bom desempenho do país no período. Com este exercício empírico, a segunda parte da dissertação pretende (i) atentar para a possibilidade de variáveis omitidas enviesarem o resultado de estudos que estimam o regime de demanda de países a partir do modelo canônico; e (ii) contribuir para o debate econômico conjuntural de crescimento liderado pela demanda no Brasil anos anos 2000, buscando indicar alguns dos fatores por trás e possíveis frentes de exaustão deste modelo de crescimento.

O resto desta dissertação está organizado da seguinte forma. No primeiro capítulo o arcabouço teórico e empírico que embasa o trabalho é apresentado. São discutidos os modelos neo-Kaleckianos canônicos, as extensões teóricas de economia aberta, endividamento e distribuição pessoal da renda, os métodos econométricos dos estudos empíricos existentes na área e as críticas a eles atribuídas.

No segundo capítulo, o modelo teórico que inclui as extensões mencionadas é desenvolvido. O capítulo se inicia com uma breve motivação, seguida da apresentação da matriz de transação da economia e da apresentação das funções comportamentais de consumo e investimento das classes econômicas. Nas subseções 4 e 5 , os equilíbrios de curto e médio prazo são analisados, seguidos das considerações finais.

O terceiro e último capítulo apresenta o exercício econométrico. A primeira subseção discute a economia brasileira nos anos 2000; a segunda descreve os dados utilizados; a terceira faz considerações sobre o método econométrico; e na quarta e quinta os resultados e as considerações finais são apresentados, respectivamente. A conclusão, as referências bibliográficas e os apêndices encerram este trabalho. 


\section{Literatura neo-Kaleckiana}

\subsection{Modelo Kaleckiano Canônico}

As teorias econômicas seminais em Kalecki (1942), Steindl (1952) e Asimakopulos (1975) têm em comum a preocupação com a relação entre emprego e produto, ciclos de negócios, crescimento e determinação de preços pelo grau de mark up da economia. Sob hipótese de concorrência imperfeita, a distribuição funcional da renda da economia é, para estes teóricos, determinada exogenamente, e influencia o nível da demanda efetiva, a realização dos lucros, além de pautar conflitos distributivos entre as classes.

Os modelos neo-Kaleckianos de crescimento e distribuição, desenvolvidos nos anos 1980 e 1990, partem dos trabalhos seminais destes teóricos e constituem hoje o principal referencial teórico na macroeconomia heterodoxa para abordar crescimento econômico liderado pela demanda efetiva, conforme ressalta Lavoie (2014). Por possuírem estrutura relativamente simples e flexível para acomodar diversas análises, conseguiram desde então promover interação razoável entre economistas de tradições distintas, como pósKeynesianos, Estruturalistas, Sraffianos e Marxistas. As versões canônicas do modelo Amadeo (1986), Rowthorn (1981), Taylor (1985), Dutt (1984), Bhaduri e Marglin (1990) - buscam avaliar como a distribuição funcional da renda afeta a demanda efetiva em economias com excesso de capacidade e competição imperfeita.

Lavoie (2014) argumenta que quatro aspectos classificam indubitavelmente um modelo de crescimento e distribuição como Kaleckiano: (i) a função investimento deve depender, dentre outras variáveis, do grau de utilização da capacidade; (ii) preços devem ser definidos exogenamente como uma margem sobre o custo de produção; (iii) a propensão marginal a consumir da renda dos salários deve ser inferior à propensão a consumir da renda dos lucros; e (iv) o grau de utilização da capacidade deve ser menor do que a unidade, isto é, a economia deve operar com capacidade ociosa e a mão-de-obra não deve configurar uma restrição de oferta.

As versões seminais do modelos são basicamente compostas por três equações associadas à distribuição da renda, à poupança e ao investimento. Assume-se que a economia opera em competição imperfeita, e, portanto, a distribuição funcional da renda é definida segundo o grau de monopólio da economia. A parcela de lucros na renda, $\pi$, é função do mark up, $\epsilon$, em cima dos custos unitários da produção e representa como a renda é distribuída entre as classes econômicas do modelo. 


$$
\pi=\frac{\epsilon}{1+\epsilon}
$$

A poupança da economia, por sua vez, é formada pela renda de cada classe multiplicada pela respectiva propensão a poupar como fica evidente na equação a seguir para a razão poupança estoque de capital. Conforme já mencionado, assalariados consomem uma parte de sua renda superior à do capitalista ${ }^{1}$, isto é, sua propensão poupar, $s_{w}$, é menor que a do capitalista, $s_{\pi}$.

$$
g^{s}=\frac{S}{K}=\left(s_{p} \pi+s_{w}(1-\pi)\right) u
$$

A função investimento, finalmente, assume diversas formas nas diferentes versões do modelo Kaleckiano. Na formulação seminal em Amadeo (1986), por exemplo, depende do componente autônomo para o animal spirit dos capitalistas, $\gamma$, e do hiato do grau de utilização em relação a seu nível natural:

$$
g^{i}=\frac{I}{K}=\gamma+\gamma_{u}\left(u-u_{n}\right)
$$

Versões posteriores incorporam, além do grau de utilização e da constante, uma variável para lucratividade; em Rowthorn (1981), Taylor (1985) e Dutt (1984), esta é a taxa de lucro,

$$
g^{i}=\gamma+\gamma_{u} u+\gamma_{r} r
$$

Em Bhaduri e Marglin (1990) leva em conta a parcela de lucro e é dita KaleckianaSteindliana. Independentemente de sua forma, a função investimento neste arcabouço incorpora além da rentabilidade esperada do investimento, a expectativa sobre a demanda, representada pelo grau de utilização da capacidade. Com isto, se distingue da visão convencional em que depende exclusivamente da margem de lucro, negligenciando a possibilidade de, mesmo na condição que esta variável seja elevada, o investimento não compensar por falta de demanda ou pela existência de capacidade ociosa.

A igualdade entre poupança e investimento, necessária para atender ao princípio da demanda efetiva, define o grau de utilização vigente da economia.

$$
g^{s}=g^{i}
$$

1 Em vários modelos Kaleckianos, os trabalhadores consomem toda a sua renda, isto é, $s_{w}=0$. 


$$
\begin{gathered}
u\left[s_{p} \pi+s_{w}(1-\pi)\right]=f(\pi, u, \alpha) \\
u^{*}=\frac{f(\pi, u, \alpha)}{s_{p} \pi+s_{w}(1-\pi)}
\end{gathered}
$$

Observe que na equação acima, a forma funcional do investimento não foi especificada; está apenas definida como função da parcela de lucro (como $r=\pi u / v$ tal função abrange os dois tipos). A derivada do grau de utilização em relação à distribuição definirá o regime de demanda da economia.

$$
\frac{d u}{d \pi}=\frac{-\left(s_{p}-s_{w}\right) u+f_{\pi}}{\left(s_{p}-s_{w}\right) \pi+s_{w}-f_{u}}
$$

O denominador positivo é a condição de estabilidade Keynesiana do modelo,

$$
\frac{\partial g^{s}}{\partial u}>\frac{\partial g^{i}}{\partial u}
$$

e, portanto, é o sinal do numerador que define qual a resposta da demanda a mudanças na distribuição funcional. Para que um aumento na parcela de salários se traduza em expansão do produto, a diminuição no investimento que isto gera, via redução da margem de lucro, deve ser mais do que compensada pelo aumento do consumo via amplificação do poder de compra dos trabalhadores, $\left(s_{p}-s_{w}\right) u>f_{\pi}$. Denominam-se tais economias wageled, isto é, economias em que o efeito dos salários reais sobre o produto é positiva. Quando, entretanto, o investimento é altamente sensível a variações nas taxas de lucros ou na sua margem e aumenta consideravelmente diante reduções nos salários reais, $\left(s_{p}-s_{w}\right) u<f_{\pi}$, a economia é profit-led. Neste caso, a redução do poder de compra dos trabalhadores é mais do que compensada pelo aumento dos investimentos na demanda agregada, acarretando relação negativa entre o nível dos salários reais e o produto.

\subsection{Desenvolvimento da literatura}

A literatura que se desenvolve a partir deste arcabouço segue duas frentes distintas. A primeira, de natureza teórica, dá ênfase à necessidade de extensões ao modelo canônico, argumentando que outras variáveis devem impactar a relação entre distribuição e demanda. Entre elas, o efeito de economia aberta (Blecker (2011); Rezai et al. (2011), Lavoie e Stockhammer (2012)); o efeito da distribuição pessoal da renda (Dutt (1992) Lavoie (1996), Tavani e Vasudevan (2014), Carvalho e Rezai (2015)); e o efeito do endividamento das famílias (Dutt (2006), Barba e Pivetti (2009), Setterfield, Kim e Rees (2016) 
Palley et al. (2010)). Há também a literatura inspirada nos ciclos de Goodwin (1967) que aborda a hipótese da distribuição funcional ser endógena no médio prazo - a possibilidade da demanda influenciar as parcelas de salário e lucro - para analisar a dinâmica recíproca entre distribuição e grau de utilização.

A segunda, de natureza empírica, busca identificar regimes de demanda de diversos países seguindo dois métodos econométricos: a abordagem estrutural, que estima equações individuais para consumo, investimento, exportações e importações (Bowles e Boyer (1995); Naastepad e Storm (2006), Stockhammer e Ederer (2008); Stockhammer Engelbert e Stefan (2009), Onaran e Galanis (2012)) e a abordagem agregada, que estima a relação geral entre distribuição e demanda através de um vetor autoregressivo - VAR (Barbosa-Filho e Taylor (2006), Naastepad e Storm (2006)). A seguir, estas duas frentes de desenvolvimento serão apresentadas, com ênfase maior nas extensões de endividamento e distribuição pessoal, por se tratarem de objetos de análise do modelo teórico desenvolvido no capítulo seguinte.

\subsection{Ciclos distributivos}

A primeira frente de expansão no âmbito teórico é a possibilidade de endogeneidade da distribuição funcional da renda baseada na ideia de conflito distributivo entre trabalhadores e capitalistas. Estes modelos são inspirados nos ciclos de Goodwin (1967), que analisa o comportamento cíclico da economia a partir da interação entre salários, lucros, emprego e produto.

No modelo de Goodwin (1967), a maior participação dos lucros na renda estimula o investimento, fomentando o emprego e a utilização da capacidade instalada da economia. O aumento da demanda por mão de obra eleva o poder de barganha dos trabalhadores, o que acarreta alargamento da parcela de salários em detrimento dos lucros. A queda nos lucros, por sua vez, reduz o investimento e a ocupação dos fatores de produção, o que reverte o ciclo expansionista dos salários e direciona renda de volta para os lucros. Assim que a economia volta à situação inicial, ocorre a retomada da atividade e o ciclo recomeça. Matematicamente a estrutura deste modelo segue as interações presa-predador descritas pelas equações de Lotka-Volterra, isto é, um par de equações diferenciais não lineares de primeira ordem, como:

$$
\begin{gathered}
\dot{\lambda}=\theta_{0}+\theta_{1} \lambda-\theta_{2} \psi \\
\dot{\psi}=\phi_{0}+\phi_{1} \psi-\psi_{2} \lambda
\end{gathered}
$$

onde o nível de emprego, $\lambda$, é a presa e a parcela de salários na renda, $\psi$, o predador. A ideia é que na fase de expansão do ciclo, quando o emprego é crescente, os salários aumentam, mas apenas até um limite, no qual a contração dos lucros é tamanha que 
contrai a taxa de acumulação de capital e, portanto, a utilização dos fatores de produção no período seguinte. Isto altera a trajetória expansionista da parcela de salários a favor dos lucros, de tal forma a incentivar o investimento e reiniciar o ciclo.

No escopo da literatura neo-Kaleckiana isto está relacionado ao canal de causalidade contrária: como a demanda efetiva afeta a distribuição funcional. Na versão "estruturalista" para os ciclos de Goodwin (1967), Taylor (2009) analisa a relação dinâmica entre distribuição e demanda, substituindo a taxa de emprego do modelo de Goodwin (1967) original, pelo grau de utilização da capacidade.

Este modelo parte de um mercado conflitivo entre trabalhadores e firmas, onde ambos lutam por maior apropriação da renda. Define uma função para a taxa de crescimento dos salários, determinada pelos trabalhadores, para a taxa de crescimento dos preços, definida pela firma, e para a trajetória da produtividade do trabalho, para, por fim, definir uma curva distributiva para a economia. A taxa de crescimento dos salários determinada pelos trabalhadores segue a forma,

$$
\hat{w}=f^{w}(u, \psi)+(1-\sigma) \xi
$$

onde os salários dependem positivamente do grau de utilização e da parcela salarial, $f_{u}^{w}, f_{\psi}^{w}>0$ - aumentam o poder de barganha dos trabalhadores - e $(1-\sigma)$ é parcela dos ganhos de produtividade, $\xi$, repassado aos salários. Os preços são definidos pelas firmas segundo a equação,

$$
\hat{P}=f^{p}(u, \psi)
$$

onde $f_{u}^{p}, f_{\psi}^{p}>0$, isto é, as firmas aumentam os preços se percebem que o grau de utilização é maior e repassam custos maiores de salários também via preços. Finalmente, a produtividade do trabalho é definida como:

$$
\hat{\xi}=f^{\xi}(u, \psi)
$$

com $f_{u}^{\xi}>0$ - efeito Kaldor-Verdoon - e $f_{\psi}^{\xi}>0$. Definindo $\omega$ como o salário real, a parcela de salários na renda pode ser expressa da seguinte maneira,

$$
\begin{gathered}
\psi=\frac{w L}{P y}=\frac{\omega}{\xi} \\
\hat{\psi}=\frac{\dot{\psi}}{\psi}=\hat{w}-\hat{P}-\hat{\xi}
\end{gathered}
$$


O lócus de pontos em que $\dot{\psi}=0$ é denominado de curva distributiva, isto é, a curva que mostra a resposta de $\psi$ a $u$ e sua inclinação pode ser examinada através da derivada total nesta curva,

$$
\frac{d u}{d \psi}=\frac{-\left(f_{\psi}^{\omega}-\sigma f_{\psi}^{\xi}\right)}{f_{u}^{\omega}-\sigma f_{u}^{\xi}}
$$

O numerador deve ser positivo para que o modelo seja estável, isto é, salários reais devem responder menos ao aumento de sua parcela do que á produtividade, pois, caso contrário, $\psi$ seguiria um processo explosivo de retroalimentação sempre que estivesse fora do equilíbrio. O sinal do denominador, portanto, é que determinará a inclinação da curva distributiva. Se $f_{u}^{\omega}>\sigma f_{u}^{\xi}$, salários respondem mais do que a produtividade a choques de demanda e a curva distributiva é positivamente inclinada e denominada profit squeeze. Se $f_{u}^{\omega}<\sigma f_{u}^{\xi}$ então aumentos no grau de utilização são apropriados pelas firmas via compressão da parcela salarial na renda e a curva distributiva é do tipo forced savings.

A relação recíproca entre demanda e distribuição funcional pode ser representada no plano $u$ versus $\psi$ pelas curvas de demanda efetiva e distributiva. Na figura 1 abaixo estão representadas algumas configurações possíveis entre as mesmas.

Figura 1 - Curva de demanda efetiva vs. Curva distributiva
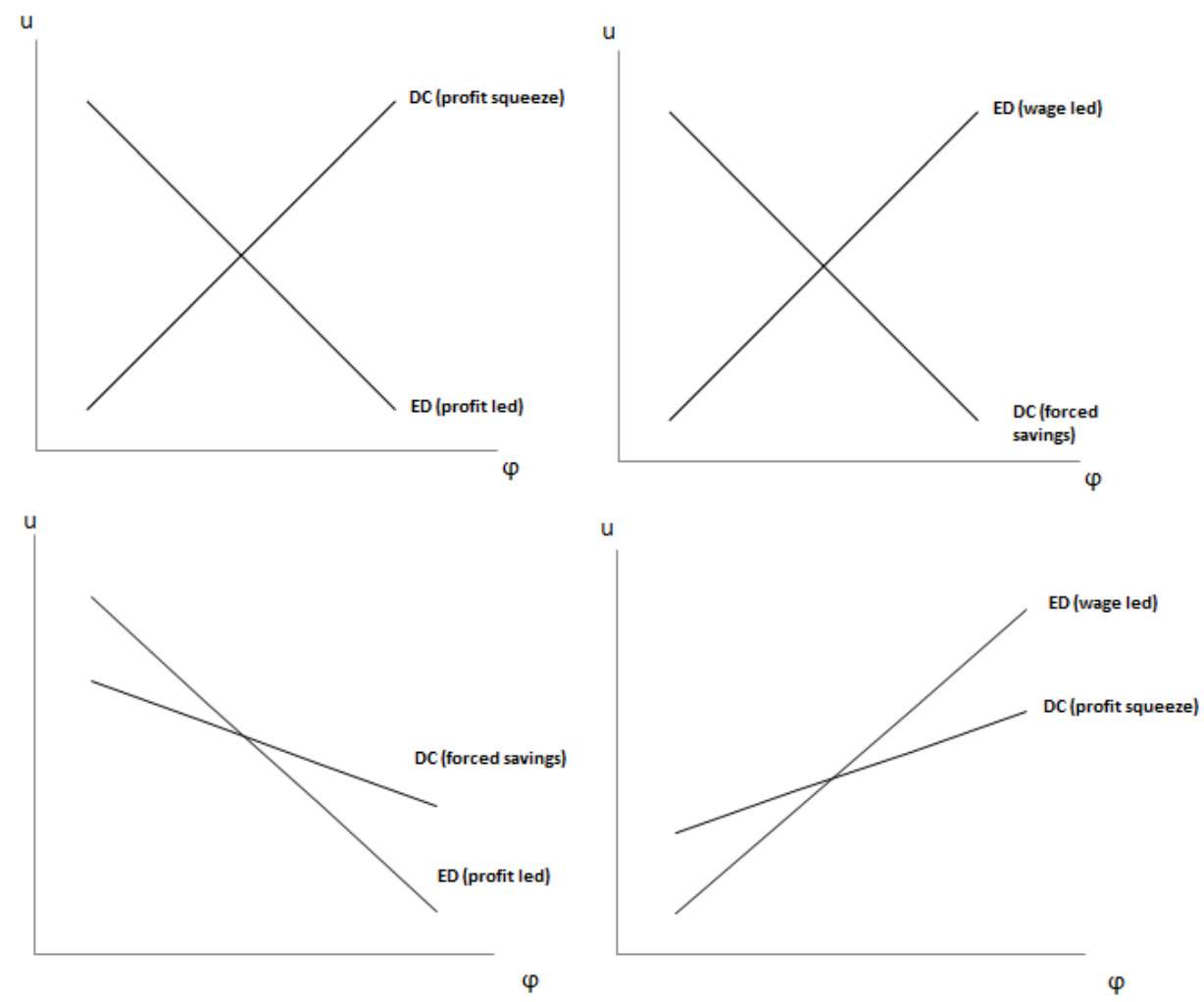


\subsection{Economia aberta}

Em se tratando de extensões teóricas ao modelo canônico, o modelo ganha versão de economia aberta em Blecker (2011), Rezai et al. (2011), Lavoie e Stockhammer (2012) e Arnim, Tavani e Carvalho (2012) - ainda que expoentes dos modelo básico já fizessem considerações sobre efeitos da abertura comercial no modelo. Blecker (2011) argumenta ser fundamental caracterizar a dinâmica macroeconômica do comércio exterior no modelo, dado o cenário atual de liberalização comercial, desregulamentação financeira e alto grau de integração entre países no atual cenário econômico. Adiciona ao modelo básico uma equação para a balança comercial da economia, também em função do estoque de capital (capital trade balance),

$$
b=b(u, u *, q)
$$

onde $q$ é a taxa de câmbio real da economia e $u *$ é o grau de utilização do resto do mundo. Assume que $b_{u}<0, b_{u *}>0, b_{q}>0$, isto é, as exportações líquidas respondem positivamente ao grau de utilização do resto do mundo e a desvalorizações cambiais e negativamente ao grau de utilização doméstico (pelo vazamento da demanda às importações). Neste caso, a derivada do grau de utilização a mudanças distributivas será:

$$
\frac{d u}{d \pi}=\frac{-\left(s_{p}-s_{w}\right) u+f_{\pi}}{\left.s_{p}-s_{w}\right) \pi+s_{w}-f_{u}-b_{u}}
$$

Observe que, no curto prazo, a única mudança decorrente da abertura econômica é que o modelo fica mais "estável" pelo vazamento de demanda às importações, representado pelo $b_{u}$. O regime de demanda definido pelo sinal do numerador continua determinado de forma análoga ao modelo canônico. No longo, entretanto, mudanças na distribuição funcional passam a ter impactos inflacionários e cambiais. Expansões nos salários reais acarretam custos de produção mais elevados e se traduzem em menor competitividade no mercado externo, comprometendo as exportações e elevando as importações. Assim o efeito de comercializar com outros países num horizonte temporal mais longo se dá no sentido de atenuar o caráter wage-led de economias com esta natureza. Blecker (2011) também faz considerações sobre o efeito de diferentes políticas neste cenário - por exemplo, desvalorização cambial, choque de produtividade, aumento do poder de barganha dos trabalhadores - e conclui que sua origem importa para o resultado final sobre a demanda e a distribuição. 


\subsection{Distribuição Pessoal}

Outra extensão interessante e bastante explorada é o efeito da distribuição pessoal da renda - especialmente a distribuição intrasalarial - sobre a demanda agregada. As evidências de piora na desigualdade de renda nas últimas décadas e, em particular, o aumento desproporcional da renda apropriada pelo 1\% mais rico (Piketty (2014)) combinadas à relativa constância da parcela de salários na renda sugerem a necessidade de se discutir como a renda dos salários é distribuída entre trabalhadores. Modelos Kaleckianos que incorporam tal extensão abandonam a hipótese de trabalhadores homogêneos para, desta forma, oferecerem explicações alternativas para o fenômeno de concentração. Dentro dos modelos Kaleckianos tal extensão foi abordada de duas formas. A primeira é introduzindo um terceiro setor econômico de produtividade menor, ou uma terceira classe econômica de trabalhadores de natureza gerencial e possivelmente improdutiva (e.g Dutt (1992), Lavoie (1996), Tavani e Vasudevan (2014), Palley (2013)); e a segunda é endogeneizando a propensão marginal a poupar dos trabalhadores (Carvalho e Rezai (2015)).

Dutt (1992), um dos primeiros a abordar o tema, não explicita exatamente a existência de uma classe de trabalhadores gerencial, mas aborda como a existência de um setor de produtividade inferior ao setor produtivo afeta o desempenho econômico. Conclui que o aumento do emprego nestes setores não necessariamente leva à estagnação econômica, desde que a função de investimento seja sensível ao grau de utilização da capacidade, que trabalhadores improdutivos consumam toda a sua renda e que preços sejam definidos como um mark up sobre o custo do trabalho, ou seja, assumindo a estrutura Kaleckiana clássica. Neste caso, o aumento do emprego no setor não produtivo pode sim aumentar a demanda efetiva, uma vez que o emprego neste setor configura uma fonte de geração de demanda efetiva em uma economia com capacidade ociosa.

Lavoie (1996) analisa o que ocorre quando se flexibiliza a hipótese de mark up fixo, isto é, quando custos com gerentes ou outros trabalhadores não produtivos em grandes firmas são repassados aos preços, e, portanto, comprometem parte do salário real dos trabalhadores produtivos. Em seu modelo, o preços das firmas é definido por uma meta de retorno, que inclui custos diretos (salários do trabalho produtivo) e indiretos (salários de gerentes, administradores e seus instrumentos de trabalho, como computadores), isto é com markup endógeno. A implicação principal desta hipótese é que quando firmas repassam, via preços maiores, custos com trabalhadores não produtivos, reduzindo indiretamente o salário real dos demais, afetam negativamente o crescimento desde que a economia esteja operando além de seu grau de utilização da capacidade médio. Por outro lado, desembolsos com capital não produtivo, que elevam a razão capital produto, têm efeito negativo na atividade econômica se a economia está com grau de utilização menor que a média padrão. Lavoie (1996) também avalia o que ocorre quando a classe não produtiva de trabalhadores têm propensão a poupar positiva. Neste caso, há dois efei- 
tos depreciativos da demanda quando o emprego de trabalhadores não produtivos cresce. Além da já mencionada redução do salário real do trabalhador produtivo que compromete seu poder de compra, há um vazamento de demanda pelo aumento da poupança proveniente dos gerentes.

Tavani e Vasudevan (2014) também apresentam um modelo Kaleckiano com três classes econômicas - capitalistas, trabalhadores (que consomem toda a renda do salário) e gerentes improdutivos - para analisar o efeito da desigualdade salarial sobre a dinâmica da demanda e da distribuição. A função dos gerentes nesta economia é de supervisionar os demais trabalhadores no lugar dos capitalistas, e para tal recebem salários maiores, que lhes possibilita alguma poupança. Para caracterizar o longo prazo, introduzem uma dinâmica distributiva de compressão salarial (dos trabalhadores a favor dos gerentes) inspirada em evidências empíricas para a economia americana ${ }^{2}$. Encontram que tanto em economias profit ou wage-led em relação à demanda efetiva, tais regimes são inequality-led quanto à dispersão salarial, uma vez que redistribuições a favor dos salários dos trabalhadores melhoram a distribuição, mas contraem a demanda efetiva. Isto ocorre, pois, neste modelo, capitalistas e gerentes têm causa comum na barganha por maior apropriação da renda; quanto maior a remuneração destes últimos, melhor seu desempenho em coordenar a produtividade dos demais trabalhadores e garantir níveis mais altos de produto. Em Tavani e Vasudevan (2014) ocorre a predominância do caráter inequality-led sobre a resposta wage ou profit-led da economia. As implicações do modelo são interessantes, por justificarem o maior alinhamento de interesses entre gerentes e capitalistas do que entre gerentes e trabalhadores.

Palley (2013) também incorpora uma terceira classe gerencial ao modelo Kaleckiano, mas aborda o conflito distributivo de longo prazo pelos pressupostos de ciclos de Goodwin (1967) que, em seu modelo, representa a disputa por maior apropriação da renda entre as duas classes assalariadas. A ideia é que quanto mais aquecido o mercado de trabalho, maior o poder de barganha de trabalhadores em relação ao dos gerentes. Palley (2013) faz considerações sobre a produtividade neste cenário, que é função positiva do nível de emprego - e poupadora de mão de obra - e função positiva da taxa de acumulação da economia. Portanto, diferentemente de Tavani e Vasudevan (2014), aqui é o maior salários dos trabalhadores em detrimento daquele dos gerentes que incentiva o progresso técnico. O resultado desse modelo é interessante por dar uma alternativa à relação sempre negativa entre redistribuições a favor dos trabalhadores e grau de utilização do regime inequality led em Tavani e Vasudevan (2014). Sugere que economias podem simultaneamente se comportar de forma wage e profit-led; o primeiro em relação a redistribuições a favor de trabalhadores, o segundo em relação à resposta a variações na distribuição funcional.

2 Empiricamente verifica-se ascensão desta classe; Duménil e Lévy (2004) traça a tendência de aumento da participação de trabalhadores de natureza gerencial e executiva, também discutida em Mohun (2014), que evidencia a aumento da parte apropriada por estes na parcela de salários total. 
Finalmente Carvalho e Rezai (2015), em vez de adicionarem uma terceira classe econômica, supõem trabalhadores heterogêneos -parcela de salários não mais dividida igualmente entre eles - com propensões a poupar positivas e crescentes em sua renda ${ }^{3}$. Isto é, trabalhadores também poupam e os de maior renda poupam mais que os de menor renda ${ }^{4}$. Há duas maneiras pela qual a concentração intrasalarial da renda afeta o regime de demanda da economia: pelo enfraquecimento do efeito de redistribuições a favor dos salários sobre o consumo e pelo efeito negativo que acarreta no multiplicador. Portanto, políticas redistributivas nos salários sempre aumentam o grau de utilização neste modelo, mas têm efeito ambíguo sobre o regime de demanda. No caso de uma economia (fracamente) wage-led, tal caráter será intensificado pela melhora distributiva. Caso seja (fortemente) profit-led, é a concentração da renda salarial que neste caso intensifica indubitavelmente o caráter profit-led.

Concluem, por meio de exercício empírico ${ }^{5}$, que a concentração de renda nas faixas de salário mais altas deve ter intensificado o caráter profit-led da economia americana, pela concentração salarial no topo enfraquecer o efeito consumo de redistribuições a favor de salário sobre a demanda agregada. Palley (2014) também defende tal resultado; argumenta que o fenômeno de concentração de renda em vários países europeus e nos Estados Unidos deve ter contribuído para regimes mais profit-led, como indicam os estudos empíricos de identificação feitos nesta área.

\subsection{Endividamento}

Outra extensão relevante que deve afetar a relação entre demanda e distribuição funcional é o efeito do endividamento das famílias. Na tradição Kaleckiana, são vários os modelos que incorporam a possibilidade de o consumo das famílias ser financiado por crédito e que avaliam como tal mecanismo afeta o grau de utilização, o crescimento e a desigualdade no curto e longo prazo (e.g Dutt (2006), Cynamon e Fazzari (2013) Hein (2012), Setterfield, Kim e Rees (2016), Setterfield e Kim (2016), Palley et al. (2010)). Tipicamente encontram três efeitos decorrentes do endividamento: seu potencial de impulsionar a demanda efetiva no curto prazo, uma vez que configura fonte alternativa aos salários para

3 Matematicamente supõem propensão a poupar dos trabalhadores, $s_{w}$, positiva e função crescente do parâmetro de desigualdade, como: $\sigma$ :

$$
s_{w}=f(\sigma), \quad f^{\prime}(\sigma)>0
$$
tado profit-led para a economia americana - dividindo a economia americana segundo o índice de gini em dois grupos - altamente concentrada e fracamente concentrada - a partir de uma série histórica (método TVAR). A partir disto, estimam o efeito da redução da parcela dos lucros sobre o regime de demanda, cujo resultado indica que o impacto da redução dos lucros é mais negativo no regime de desigualdade alta do que na baixa, conforme predito pelo modelo. 
manutenção do consumo; seu caráter concentrador da renda, uma vez que quanto maior o estoque da dívida contraída, maior o custo de seu serviço e consequentemente maior a transferência de renda de trabalhadores a capitalistas ou rentistas; e finalmente seu caráter desestabilizador no sistema financeiro. Há diversas formas de tratar o endividamento dentro do escopo pós-Keynesiano. A seguir, algumas delas serão apresentadas.

Dutt (2006) incorpora o endividamento em um modelo do tipo Steindliano similar ao de Bhaduri e Marglin (1990), partindo da hipótese de que o trabalhador escolhe a variação do estoque de sua dívida a cada período do tempo de acordo com sua renda disponível (após o pagamento de seu serviço) pelo desejo de emulação do consumo da classe capitalista (ideia de consumo conspícuo presente em Veblen (1988)). Matematicamente, seu nível desejado de empréstimo é definido em Dutt (2006) como:

$$
\dot{D}=\beta(\psi Y-i D)
$$

Onde $D$ representa o estoque da dívida, $\dot{D}$ sua variação e $\beta$ o parâmetro de quanto trabalhadores desejam consumir além de sua renda do trabalho. Apesar de assumir que tal parâmetro é definido pelos trabalhadores (demanda), Dutt (2006) observa que também pode ser interpretado como alguma restrição de liquidez imposta pelo sistema financeiro. Independentemente da justificativa, tal configuração implica propensão a consumir dos trabalhadores maior que a unidade:

$$
C_{w}=\psi Y-i D+\dot{D}=(1+\beta)(\psi Y-i D)
$$

A conclusão deste modelo é que o endividamento e o grau de alavancagem $(\beta)$ têm efeito positivo sobre o consumo e, consequentemente, sobre o nível de atividade econômica no curto prazo. No longo, entretanto, este efeito é ambíguo, pois o endividamento de assalariados redistribui renda em direção aos que possuem maior propensão a poupar capitalistas - o que pode ter efeito contracionista sobre a demanda agregada. O problema de concentração da renda tende a se agravar quanto mais fraca a demanda autônoma por investimento, isto é, quando o consumo induzido pelo endividamento é mais crucial para contrabalancear tendências à estagnação.

Abordagens mais recentes fundamentam e até modelam o desejo dos trabalhadores de copiarem o consumo capitalista ou rentista - consumo conspícuo - que justifica o endividamento no modelo acima (Cynamon e Fazzari (2013), Ryoo e Kim (2014) Barba e Pivetti (2009), Kapeller e Schütz (2015)). Estes contestam a explicação baseada na hipótese de expectativas racionais, na qual o endividamento é decorrente da meta de suavização de consumo de agentes forward looking que otimizam a utilidade intertemporal. 
Como argumenta Ryoo e Kim (2014), para analisar a relação entre consumo e endividamento deve-se levar em conta o meio social e a influência de campanhas publicitárias em meios de comunicação nas decisões de consumir dos trabalhadores. O desejo de imitar os padrões de consumo das classes mais altas configura motivação forte o suficiente para a predisposição ao endividamento pelos trabalhadores. Por outro lado, salientam Ryoo e Kim (2014), isto não seria possível sem flexibilização do lado da oferta: a introdução de novas práticas e produtos no sistema financeiro; a flexibilização das regras de concessão de empréstimos; a ascensão do fenômeno de securitização; e a desregulamentação financeira, certamente contribuíram para a acessibilidade ao crédito.

Setterfield e Kim (2016) e Setterfield, Kim e Rees (2016) analisam o papel do crédito em financiar o consumo conspícuo em uma economia formada por trabalhadores produtivos, gerentes e capitalistas, divididos entre as classes rentista e trabalhadora. A justificativa para esta divisão bilateral vem de Palley (2013) que argumenta haver uma distinção nos padrões comportamentais de consumo entre os $80 \%$ na base (classe trabalhadora) e os $20 \%$ no topo (classe média e média alta que engloba trabalhadores ricos) da pirâmide distributiva nos EUA. No contexto do modelo, os trabalhadores se endividam para imitar o consumo dos rentistas. Considera, entretanto, que trabalhadores são heterogêneos e poupam parte da renda ${ }^{6}$. A função para variação no estoque da dívida é definida como uma fração $\beta^{7}$ do hiato entre o consumo desejado, $C^{T}$ (target consumption), que é função do consumo rentista, e o consumo possível $C^{w}$, sua renda disponível descontada da poupança.

$$
\dot{D}=\beta\left(C^{T}-C^{w}\right)
$$

As implicações do modelo são diferentes em Setterfield e Kim (2016) e Setterfield, Kim e Rees (2016) pela forma como definem a poupança dos trabalhadores. Setterfield e Kim (2016) assumem que os trabalhadores decidem primeiro quanto consomem de sua renda bruta do trabalho, segundo sua propensão a consumir, e usam o resíduo para ou fazer frente ao serviço de sua dívida ou acumular ativos:

$$
S_{w}=\left(1-c_{w}\right) W N-i D
$$

$6 \quad$ Pode parecer inconsistente que trabalhadores se endividam e poupam ao mesmo tempo, mas Setterfield e Kim (2016) argumenta que constituem uma classe heterogênea em um ambiente de incerteza com mercado de crédito imperfeito. Neste cenário é razoável supor que existam famílias que apenas poupam, que apenas se endividem e outras que desejam consumir além de sua renda tomando empréstimos sem abrir mão de manter ativos.

7 Tal parâmetro representa a restrição ao crédito imposta pelos bancos definido com base em aspectos como a solvabilidade ou a renda das famílias na hora de decidir quanto emprestar. 
Portanto, a poupança independe da dimensão da dívida ${ }^{8}$. O resultado desta configuração é a primeira vista contra intuitivo: a concentração de renda a favor de rentistas devido ao pagamento do serviço da dívida eleva o grau de utilização e o crescimento. Isto ocorre, pois os trabalhadores poupam independentemente do consumo conspícuo, que é atendido exclusivamente pelo endividamento. A parte da poupança usada para pagar os encargos da dívida é transferida a rentistas que então aplicam uma propensão marginal a consumir positiva, configurando uma injeção de demanda, mesmo sob a hipótese Kaleckiana de propensão a poupar dos rentistas menor que a dos trabalhadores. Quanto ao impacto sobre o regime de demanda, concluem que a existência de poupança do trabalho e emulação do consumo rentista baseado em endividamento fortalece a tendência profit-led da economia. Redistribuições a favor dos lucros aumentam o consumo capitalista, incentivam o endividamento e a emulação pela classe trabalhadora, que por conseguinte amplia consumo agregado, ainda que a renda dos salários caia, além do usual efeito da lucratividade sobre o investimento. Observe que este resultado é oposto a Dutt (2006); naquele a compressão da parcela salarial sempre reduzia o endividamento, que era proporcional à renda disponível. O modelo é sustentável no longo prazo, desde que o valor de estado estacionário da razão dívida-capital seja tal que $S_{w}>i D *$, isto é, que a poupança seja suficiente para honrar o serviço da dívida ${ }^{9}$.

Setterfield, Kim e Rees (2016) abandonam tal hipótese e definem a poupança como uma fração da renda disponível após o pagamento do serviço da dívida, conforme:

$$
S_{w}=\left(1-c_{w}\right)(W N-i D)
$$

Concluem que esta modificação contribui para a estabilidade do equilíbrio do modelo e acarreta efeitos quantitativos e qualitativos em sua macrodinâmica, afetando sua estática comparativa (se o crescimento e demanda são profit ou wage-led).

Em Ryoo e Kim (2014), a interação entre emulação e distribuição funcional endógena também é explorada, mas com um ajuste de longo prazo do tipo Kaldoriano, isto é, a variável de ajuste torna-se a distribuição funcional ao invés do grau de utilização. A desigualdade inicial da renda entre rentistas e trabalhadores gera padrões de consumo diferentes entre as duas classes e incentiva trabalhadores ao consumo conspícuo. No curto prazo, isto estimula o endividamento, que surte efeito positivo na demanda efetiva. No mecanismo de ajuste Kaldoriano, o maior grau de utilização contrai a renda dos salários a favor dos rentistas, o que levaria a maior demanda por empréstimos para que o consumo fosse mantido. O desejo de manter o padrão de consumo dos rentistas é portanto cumulativo e insustentável, e a estabilidade deste modelo depende de alguma restrição na

8 Justifica que tal configuração reflete o fato estilizado de propensão a poupar dos trabalhadores decrescente em concomitância ao aumento do endividamento na economia Americana nas últimas três décadas apontado por Barba e Pivetti (2009).

9 Observe que em Dutt (1992) esta condição é hipótese inicial. 
oferta, isto é, de um limite na predisposição a emprestar dos bancos, resultado semelhante a Setterfield e Kim (2016) Ryoo e Kim (2014). Concluem que é essencial um papel ativo do setor financeiro em acomodar a demanda por empréstimos levando em conta a renda disponível dos trabalhadores.

Em Hein (2012) a variação da dívida a cada período é dada por uma fração $\zeta$ da poupança capitalista e o consumo conspícuo impacta positivamente a parte da poupança capitalista destinada a empréstimos. Matematicamente, a variação no estoque da dívida assume a forma:

$$
\dot{D}=\zeta s(\pi Y+i D)
$$

Isto é, capitalistas decidem quanto consomem e em seguida como alocam sua poupança entre ações das firmas e títulos da dívida dos trabalhadores. Hein (2012) encontra que, sob condições de estabilidade, pode emergir um regime debt led no qual o efeito expansionista do aumento da razão dívida-capital sobre a demanda agregada supera o efeito contracionista da elevação de seu serviço. Hein (2012) fala ainda sobre a existência de um "paradoxo da dívida"; a maior parcela da poupança de rentistas destinada a empréstimos diminui a razão estoque da dívida-renda pelo efeito positivo dominante sobre a renda e o estoque de capital.

Vale uma observação à configuração dos modelos discutidos acima ressaltada por Fagundes (2017). Ao incorporarem endividamento em modelos tradicionais do modelo Kaleckiano, supõem que o crédito é proveniente da renda dos capitalistas ou dos rentistas. Em Dutt (2006) e Hein (2012) não existe um sistema financeiro e o fluxo de renda para prover o empréstimo é proveniente de parte da poupança capitalista ${ }^{10}$. Em Setterfield e Kim (2016) e Setterfield, Kim e Rees (2016) há sistema bancário com a função de intermediar depósitos de rentistas e trabalhadores e oferta de crédito.

Desta forma, aproximam-se da teoria de fundos emprestáveis, com bancos atuando como mediadores entre poupança e empréstimos. Portanto, ignoram o âmbito monetário da economia, que oferece como alternativa provisão de crédito por moeda endógena. Esta hipótese também está presente nos modelos de endividamento em Palley $(1996)^{11}$

A alternativa a essa abordagem é a introdução de um sistema bancário que mantém depósitos e concede empréstimos suprindo toda a demanda existente. Neste caso, o crédito é gerado via criação de moeda endógena por Bancos Centrais, conforme é feito no arcabouço de modelos Stock-flow em Godley e Lavoie (2012).

10 Apesar de assumir que o a provisão do crédito vem do capitalista, Dutt (2006) mantém sua função consumo na forma $C_{c}=(1-s)[(1-\psi) Y+i D]$, isto é, sem descontar $\dot{D}$ com o intuito de manter o modelo mais simples. Logo assume indiretamente que o montante emprestado não influencia o consumo e a poupança da classe.

11 No modelo para endividamento em Palley (1996) a configuração que desconta os empréstimos da renda dos capitalistas $C_{c}=(1-s)[(1-\psi) Y+i D-\dot{D}]$ é usada, portanto, parte completamente da hipótese de fundos emprestáveis. 


\subsection{Estudos empíricos}

A literatura empírica da área inclui uma gama ampla de estudos que buscam identificar regimes de demanda para diversos países. São dois os métodos destes estudos: a abordagem estrutural, que estima equações individuais para consumo, investimento, exportações e importações; e a abordagem agregada, que estima a relação geral entre distribuição e demanda através de um vetor autoregressivo (VAR).

No primeiro, busca-se captar a resposta particular de cada um dos componentes da demanda a variações na distribuição funcional e distinguir os efeitos de economia aberta e fechada. Parte-se da seguinte equação,

$$
A D=C(Y, \psi)+I\left(Y, \psi, z_{I}\right)+N X\left(Y, \psi, z_{N X}\right)+G\left(Y, z_{G}\right)
$$

em que $\psi$ é a parcela de salários na renda e $z$ representa variáveis exógenas para cada componente da demanda. Assume-se que no equilíbrio do mercado de bens, o produto é igual à demanda agregada $\left(Y^{*}=A D\right)$. Para definir qual a natureza do regime de demanda, diferencia-se $Y^{*}$ com relação a $\psi$ e rearranjando os termos, têm-se:

$$
\frac{d Y^{*}}{d \psi}=\frac{h_{2}}{1-h_{1}}
$$

onde $h_{1}=\left(\frac{\partial C}{\partial Y}+\frac{\partial I}{\partial Y}+\frac{\partial N X}{\partial Y}+\frac{\partial G}{\partial Y}\right)$ e $h_{2}=\left(\frac{\partial C}{\partial \psi}+\frac{\partial I}{\partial \psi}+\frac{\partial N X}{\partial \psi}\right)$.

O termo $1 /\left(1-h_{1}\right)$ é um multiplicador padrão e deve ser positivo para que o modelo seja estável. O sinal da derivada depende, portanto, do sinal do numerador, que pode ser determinado empiricamente através da estimação de equações individuais para consumo, investimento e exportações líquidas uma a uma. Se $h_{2}>0$, e portanto, $\partial Y^{*} / \partial \psi>0$, o regime de demanda é wage-led; se o contrário ocorre, o regime é do tipo profit-led. $\mathrm{O}$ componente gastos do governo é ignorado nestas estimações, pela presunção de que no longo prazo o orçamento do governo estaria equilibrado e pelo foco da análise recair sobre a dinâmica do setor privado. A maior vantagem deste método é conseguir decompor o efeito da mudança distributiva sobre cada componente da demanda. É, entretanto, alvo de inúmeras críticas, entre elas, a hipótese de exogeneidade da variável distributiva; a possibilidade de variáveis omitidas nas estimações; a possível não linearidade de regimes de demanda; a ausência de considerações sobre o horizonte temporal da análise; e falta de interação do mercado de bens com os demais da economia.

Skott (2015) é bastante crítico a tal método e problematiza a terminologia "regime de crescimento" ou "regime de demanda", que emerge desses trabalhos, por sugerir que a relação de causalidade entre distribuição e demanda só opera em um sentido (a primeira "causando" a última). A distribuição também está sujeita à trajetória da demanda, aos 
arranjos institucionais e ao conflito distributivo, como aborda a literatura Kaleckiana inspirada em ciclos de Goodwin (1967).

Este é exatamente o pressuposto teórico dos estudos empíricos que utilizam o método VAR, isto é, a estimação de um sistema de equações dinâmicas simultaneamente em um vetor autoregressivo. Esta estratégia busca capturar as interdependências lineares entre as séries temporais e lida bem com a relação de reciprocidade entre as variáveis. Matematicamente estima um sistema dinâmico, conforme:

$$
\begin{gathered}
\dot{u}=g(u, \psi)=u\left(\phi_{0}+\phi_{u} u+\phi_{\psi}\right) \\
\dot{\psi}=h(u, \psi)=\psi\left(\theta_{0}+\theta_{u} u+\theta_{\psi} \psi\right)
\end{gathered}
$$

cuja dinâmica é avaliada no equilíbrio $\dot{u}=\dot{\psi}=0$.

A análise de seus resultados, como lembram Onaran e Galanis (2012), exige cuidado, pois não é possível detectar precisamente a relação entre os componentes da demanda individualmente e a distribuição; além de não permitir a distinção entre os efeitos da demanda na economia aberta e fechada. O método também exige considerações teóricas sobre como o ciclo econômico representado pelo grau de utilização deve impactar a repartição da renda entre salários e lucros, e dialoga, portanto, com a literatura inspirada em Goodwin (1967) apresentada acima.

Em geral, estudos para países desenvolvidos encontram que os salários crescem com o ciclo e que a demanda responde negativamente aos mesmos, ou seja, predominância de regimes do tipo profit-led ( eg. Barbosa-Filho e Taylor (2006);Diallo et al. (2011), Franke, Flaschel e Proano (2006), Kiefer e Rada (2015)). Em Barbosa-Filho e Taylor (2006), o resultado, através da análise de longo prazo para a economia americana, sugere, de fato, curvas de demanda do tipo profit-led, curva $\dot{u}=0$, e de curva distributiva, $\dot{\psi}=0$, do tipo profit squeeze. Ou seja, choques distributivos permanentes (deslocamento na curva distributiva) levam a aumentos da parcela de salários às custas do grau de utilização, enquanto choques de demanda positivos (deslocamento da curva de demanda para fora) aumentam ambos o grau de utilização e a parcela salarial.

Estudos que estimam a resposta de cada componente da demanda agregada separadamente (e.g. Bowles e Boyer (1995), Naastepad e Storm (2006), Stockhammer Engelbert e Stefan (2009), Hein e Vogel (2008), Onaran e Galanis (2012)), geralmente caracterizam a demanda doméstica como wage-led, mas ao considerarem o efeito distributivo sobre as exportações líquidas, verificam alternância no regime para profit-led, especialmente em pequenas economias abertas. Stockhammer e Onaran (2012) constatam empiricamente que pequenas economias aberta, como Áustria e Holanda, tendem a ser mais profit-led que grandes blocos econômicos como a área do Euro, ou os Estados Unidos. Concluem que 
quanto maior a dependência de países ao mercado externo, e portanto, maior sensibilidade aos preços internacionais, mais estes tendem a ser fracamente wgae led ou profit-led.

Para o caso brasileiro, Araújo e Gala (2012) encontram resultado semelhante. Estimam equações individuais para a resposta dos componentes da demanda à distribuição funcional e encontram que, apesar do padrão de crescimento doméstico ser do tipo wageled, a inclusão do setor externo o torna profit-led, isto é, a economia brasileira (19602010) responde de forma positiva a aumentos da parcela de lucro na renda. Atribuem a tal resultado a globalização, a sensibilidade do produto às exportações líquidas e apontam para o potencial impacto positivo que políticas cambiais de desvalorização teriam sobre o produto.

Bruno (2005), que realiza estudo num horizonte temporal mais longo com dados anuais, constata dois padrões de acumulação ${ }^{12}$ : um regime do tipo profit-led nos anos 1970 a 1980, que cessa no período 1991 a 2001, no qual o investimento e a demanda efetiva passam a ser mais sensíveis à participação dos salários na renda, caracterizando um regime wage-led.

Tomio (2016) também realiza estimação do regime de demanda pelo método das equações separadas com dados anuais, mas encontra resultado wage-led para todo o período 1956-2008. A razão da diferença em relação aos resultados de Bruno (2005) e Araújo e Gala (2012) pode ser atribuída a dois fatores: a ausência de significância da parcela de lucro na estimação da função investimento, também verificada nos dois outros estudos; e o efeito negativo da parcela de lucro na estimação para as exportações líquidas. Observe que este último resultado vai ao encontro do que é usualmente esperado na literatura Kaleckiana que trata de economia aberta e é contrário ao encontrado nos dois outros estudos $^{13}$. De toda forma, seu método econométrico é apresentado com mais clareza - são relatados testes de raiz unitária, de cointegração e há justificativa para todas as especificações utilizadas - do que em Araújo e Gala (2012) e Bruno (2005), nos quais a ausência de uma discussão mais detalhada sobre o método gera questionamento sobre a robustez dos resultados.

Em Avritzer, Freitas e Braga (2014), o objeto de estudo é a relação entre distribuição funcional e crescimento no período 1952 a 2008. Apesar de não se tratar de um estudo

12 Em seu estudo, Bruno (2005) divide os dados em dois grupos devido a mudança na tendência da razão produto-capital $(Y / K)$; enquanto de 1970 a 1990 é descrente - acumulação de capital crescendo mais que produto -, de 1971 em diante se estabilizia. Por isso realiza dois exercícios separados para estimar o regime de demanda.

13 Tomio (2016) oferece explicações para este resultado. Primeiro o atribui à relação discutida em Hein e Vogel (2008) de que mudanças na parcela de lucro capazes de afetar as exportações líquidas são provenientes de mudanças no mark up e seus determinantes (poder de sindicatos, grau de competitividade dos preços, e custos) ao invés do salário nominal ou da taxa de câmbio. Também salienta que pode ser proveniente de doença Holandesa (Pereira (2010)), da rápida liberalização financeira (Carvalho (2008)), ou do aumento de empresas multinacionais no país, que usufruem da mão de obra barata no país para exportar bens. 
que estima o regime de demanda propriamente dito, cabe mencioná-lo por ser inspirado na mesma literatura e por se contrapor aos demais estudos sobre economia brasileira ao utilizarem o método VAR. Estimam três especificações econométricas distintas com variáveis para o investimento, a taxa de crescimento econômico e a participação de salários na renda. Seus resultados sugerem (i) investimento endógeno ao nível de atividade econômica, como supõe o modelo neo-Kaleckiano, e (ii) ausência ${ }^{14}$ de significância entre taxa de crescimento e distribuição funcional da renda - tanto pelos efeito taxa quanto nível.

\subsubsection{Críticas aos estudos empíricos}

Observe que os estudos empíricos relatados acima para o Brasil e o resto do mundo não levam a conclusão unânime sobre alguma tendência comum entre os regimes de demanda dos países, inclusive oferecem em alguns casos resultados ambíguos para um mesmo país. Entre prováveis fontes para a heterogeneidade de resultados estão a possibilidade de variáveis omitidas - de não se considerar as extensões teóricas discutidas acimas - relevantes para cada país; a ausência de considerações sobre o horizonte temporal da análise Blecker et al. (2015); a suposição de exogeneidade da variável distributiva no primeiro método (Skott (2015)); a possibilidade de não linearidade dos regimes ${ }^{15}$ (Nikiforos e Foley (2012), Nikiforos (2014) e Palley (2014)); e a necessidade de se considerar a interação com outros mercados além do de bens (Schoder et al. (2016). Além disto, no âmbito normativo, o fato de a variável distributiva não ser exógena não permite que os resultados desses estudos direcionem políticas econômicas.

Conforme já mencionado, Skott (2015) acredita que o pressuposto de distribuição estática enfraquece os resultados de estimações na forma reduzida. Esta crítica também é endereçada por Palley (2014), que argumenta que o regime de demanda não é exógeno ao seu contexto, que não é uma tendência natural e única de cada economia. A caracterização de economias como profit ou wage-led é provisória; está sujeita às políticas macroeconômicas em vigor e pode oscilar de um caráter para o outro. Palley (2014) ressalta, por exemplo, que o fenômeno de concentração de renda em vários países europeus e nos Estados Unidos deve ter contribuído para regimes mais profit-led, como indicam os estudos empíricos de identificação feitos nesta área.

14 Avritzer, Freitas e Braga (2014) encontram relação significante entre as duas variáveis na terceira especificação relatada no trabalho, quando partem de relação de cointegração entre as variáveis. Ao realizarem o teste de raiz unitária com a possibilidade para quebra estrutural (Gregory e Hansen) encontram a não rejeição da hipótese nula de não cointegração das três variáveis duas a duas. O problema é que tal teste pressupõe exogeneidade da variável explicativa, o que não é razoável de se assumir em nenhum dos três casos, conforme os próprios autores reconhecem. Posto isto, o resultado desta especificação é que a participação dos salários é negativamente negativamente relacionada à renda da economia brasileira antes de 1994 e positivamente e significante após 1994. Avritzer, Freitas e Braga (2014) assinalam que tal resultado é compatível com a possibilidade de mudança de regime, uma das críticas aos estudos de regime de demanda que será discutida a seguir.

15 Caso contrário, uma economia de natureza wage-led encontraria seu grau de utilização e crescimento máximo no limite em que toda a renda fosse destinada a salários, hipótese implausível. 
No âmbito da determinação de políticas econômicas, a endogeneidade também é problemática, uma vez que a variável distributiva não é passível de controle direto. Skott (2015) também retoma a crítica de Lucas, que diz que a constatação de correlação entre séries temporais por si só não basta para plotar políticas econômicas. Mais relevante seria tentar tratar de como um mudança no salário mínimo, na taxa de câmbio, em transferências do governo ou no molde de tributação, isto é, variáveis de intervenção direta, impactariam distribuição e crescimento.

Blecker et al. (2015) ainda adiciona que é necessário se considerar o horizonte temporal da análise (distinção das tendências de curto e longo prazo). Conclui que por esta e todas as demais razões elencadas acima, pesquisas empíricas na área deviam adaptar os modelos estruturais a sistemas dinâmicos que considerem outras esferas da economia além da demanda agregada, e cujas simulações potencialmente captariam interações ignorados na estimação por MQO. 


\section{Modelo}

\subsection{Motivação}

Conforme discutido no capítulo anterior, as extensões aos modelos de endividamento e distribuição pessoal em modelos Kaleckianos foram bastante exploradas separadamente, e até conjuntamente, porém com ênfase na análise da relação entre distribuição funcional e a dívida. Os modelos de crédito existentes que levam em conta a distribuição pessoal ou classes econômicas híbridas enfatizam o fenômeno do consumo conspícuo, mas não chegam analisar uma relação recíproca e dinâmica de médio prazo entre a distribuição pessoal e o endividamento.

Neste contexto, o objetivo deste capítulo é explorar o caráter dúbio do crédito - de potencializar o consumo no curto prazo, mas concentrar a renda disponível no médio - em um modelo que incorpore outra forma de concentração de renda além da funcional. Isto será implementado através de considerações sobre a desigualdade salarial e sob a hipótese de renda híbrida da classe rica. Esta configuração se justifica pela evolução na estrutura distributiva - funcional e pessoal- no Brasil e no mundo ao longo dos últimos anos.

Em países desenvolvidos - EUA, França, Suécia, Reino Unido, Alemanha - o fenômeno de concentração de renda que tem sido verificado nas últimas décadas volta ao centro do debate econômico com a publicação de Piketty (2014). Conforme aponta Setterfield e Kim (2016), a piora distributiva a partir da década de 1980 se manifesta de diversas formas, entre elas: o aumento da parcela de lucro na renda; a crescente participação de gerentes assalariados na renda total do salário que Piketty (2014) descreve como a "ascensão dos superexecutivos"; e o aumento considerável da desigualdade dentre os 10\% mais ricos. Neste cenário era natural se esperar redução nas taxas de crescimento do consumo agregado em decorrência do menor crescimento relativo da renda na base da pirâmide distributiva destes países, contudo, o que se verifica é tendência contrária.

Isto ocorre, pois o endividamento passa a funcionar como fonte alternativa de financiamento ao consumo das famílias. A manutenção de taxas de crescimento elevadas do consumo em todos os espectros distributivos na consumer age (Cynamon e Fazzari (2013)) que se inicia a partir da década de 1980 e prescinde a crise econômica, só é possível devido à fácil acessibilidade ao crédito. Cynamon e Fazzari (2013) argumentam que o aumento da desigualdade é uma das principais causas da elevação desenfreada do endividamento e estimam que em torno de $8 \%$ de demanda agregada nos EUA pré-crise era baseada em endividamento insustentável. Dados em Ryoo e Kim (2014), por sua vez, mostram que a razão endividamento das famílias em relação ao PIB nos estados Unidos 
passa de 45\% em 1975 para 100\% em 2006. Barba e Pivetti (2009), Setterfield e Kim (2016) e Palley (2015) observam diferença nos padrões de renda e comportamentais de consumo dos $80 \%$ mais pobres e dos $20 \%$ mais ricos; os primeiro passam a contar com o endividamento para manter seu consumo no patamar almejado frente ao baixo crescimento relativo de sua renda. Se por um lado conseguiu impedir um possível efeito devastador do consumo sobre a demanda efetiva, por outro, o endividamento insustentável contribuiu para a vulnerabilidade do mercado financeiro pré crise, como argumentam Cynamon e Fazzari (2013).

No caso brasileiro, o endividamento em massa é um fenômeno relativamente recente quando comparado às práticas de países desenvolvidos descritas acima. Conforme apontam Serrano e Summa (2012) e Carvalho e Rugitsky (2015), a razão concessão de crédito a pessoas físicas em relação ao PIB alterna sua tendência historicamente constante e passa a assumir trajetória crescente apenas de 2003 em diante (a partir de 2010 de forma menos significativa). Isto ocorre devido à inclusão da base da pirâmide distributiva ao mercado de crédito, principalmente pela institucionalização em 2004 do mecanismo de crédito consignado - um tipo de empréstimo cujo pagamento se dá através de dedução automática da folha salarial dos trabalhadores. Em se tratando da análise dos fatores condicionantes de tal fenômeno, diferentemente dos países desenvolvidos, Carvalho e Rugitsky (2015) e Serrano e Summa (2012) argumentam que aqui a melhora distributiva ${ }^{1}$, decorrente da formalização do mercado de trabalho e dos ganhos reais sucessivos no salário mínimo no período, é que parece ter sido o agente viabilizador para o acesso generalizado ao crédito.

Partindo de tais cenários, o modelo aqui desenvolvido pretende abordar estas e outras relações possíveis entre distribuição da renda e endividamento. O modelo será estruturado da seguinte forma. Seguindo Barba e Pivetti (2009) e Setterfield e Kim (2016) a economia será composta de duas classes econômicas: a base da pirâmide ou os trabalhadores "pobres", formada exclusivamente por assalariados; e o topo da pirâmide ou os ricos, por trabalhadores gerentes, que ganham salários maiores do que os demais, e capitalistas donos das firmas e do sistema bancário. Pode-se pensar numa divisão entre os 80\% na base e os $20 \%$ mais ricos, como defende Palley (2015) por diferenças no comportamento de consumo, ou também nos $99 \%$ em comparação aos $1 \%$ pela evidente distinção entre as taxas de crescimento de sua renda, como assinala Piketty (2014). Independentemente de como se conceba tal divisão, o crucial aqui é a distinção entre a origem e magnitude de sua renda, e seus padrões comportamentais de consumo, endividamento e poupança. Os trabalhadores financiarão sua propensão a consumir maior que a unidade através de empréstimos, enquanto os ricos pouparão parte de sua renda, que será alocada em moeda

1 Ao se falar em melhora distributiva, estamos nos referindo à queda na dispersão salarial medida pelo índice de Gini para salários da PNAD 2008 e PNAD 2012. 
depositada nos bancos.

\subsection{Consistência entre fluxos e estoques}

A Tabela 1 reproduz a matriz de transação desta economia. Nela estão esquematizadas as relações das duas classes com as firmas e com o sistema bancário. Suas descrições mais detalhadas serão feitas ao longo da exposição do modelo nas seções seguintes. Contudo, cabe mencionar de antemão algumas considerações sobre o sistema bancário, o financiamento da dívida e do investimento.

O lucro total da firma, П, será parcialmente distribuído à classe rica no montante $\tau \Pi$ e parcialmente retido e empregado no financiamento do investimento, $(1-\tau) \Pi$. Observe que, sob a hipótese de uma função de investimento com comportamento autônomo, conforme ficará evidente adiante, os lucros retidos nem sempre se igualarão ao investimento de fato realizado a cada período. A diferença entre os dois montantes ocasionará depósitos bancários das firmas, $\dot{M}_{f}$. Assume-se que os lucros retidos serão sempre altos o suficiente para atender ao investimento desejado. Isto não requer $(1-\tau) \pi>I$ em todos períodos, uma vez que as firmas podem ter saldo em depósitos bancários. Em suma, assume-se que as firmas nunca recorrem a empréstimos bancários para financiarem seu investimento. A análise de endividamento neste modelo se restringe ao crédito obtido para financiar consumo.

O sistema bancário é propriedade da classe rica e possui duas atribuições: criar moeda para financiar a demanda por crédito dos pobres; e manter os depósitos em moeda dos ricos e das firmas. As famílias pobres tomam empréstimos a cada período seguindo sua equação comportamental, discutida mais adiante, e pagam de serviço da dívida a taxa de juros $i$ sobre o estoque $D$. A classe rica deposita nos bancos a sua poupança que não foi empregada em consumo na forma de moeda, $\dot{M}_{r}$ e as firmas depositam a diferença entre o montante de lucro retido e o investimento realizado a cada período também em moeda, $\dot{M}_{f}$.

Conforme aponta Lavoie (2014), a hipótese de oferta de moeda endógena e acomodacionista na demanda, quase unânime na tradição pós-Keynesiana, significa que os bancos são criadores de crédito, e portanto de poder de compra sob demanda dos trabalhadores. Na matriz de transação esta hipótese se traduz no canal de causalidade de créditos para depósitos, isto é, os depósitos bancários, $\dot{M}$, são gerados com as transações econômicas entre famílias e firmas após a concessão de créditos bancários, $\dot{D}$. Portanto, se contrapõem a teoria de fundos emprestáveis em que depósitos ou poupança são necessários para geração de crédito.

A ausência de remuneração aos depósitos dos ricos e das firmas pelo sistema ban- 
cário foi uma hipótese simplificadora assumida por a classe rica ser dona dos bancos e das firmas. Os lucros dos bancos, $P_{\text {bancos }}$, será então o fluxo do pagamento da dívida dos pobres, $i D$, que é transferido inteiramente aos ricos e eleva sua renda disponível. Esta configuração facilita a análise sobre o possível caráter concentrador do endividamento no médio prazo.

Tabela 1 - Matriz de Transação

\begin{tabular}{llllllll} 
Operações & Classe Pobre & Classe Rica & $\begin{array}{l}\text { Firmas } \\
\text { Corrente }\end{array}$ & Capital & $\begin{array}{l}\text { Bancos } \\
\text { Corrente }\end{array}$ & Capital & Total \\
\hline \hline Consumo & $-C_{P}$ & $-C_{R}$ & $+C_{T}$ & & & \\
Investimento & & & $+I$ & $-\dot{K}$ & & 0 \\
Salários & $+W_{L} L$ & $+W_{G} G$ & $-W_{T}$ & & & 0 \\
Lucros & & & & & & & 0 \\
-Firmas & & $+\tau \Pi$ & $-\Pi$ & $+(1-\tau) \Pi$ & & & 0 \\
-Bancos & & $+P_{\text {bancos }}$ & & & $-P_{\text {bancos }}$ & 0 \\
Juros dívida & $-i D$ & & & & $+i D$ & & 0 \\
Variações & & & & & & $+\dot{M}$ & 0 \\
-Moeda & & $-\dot{M}_{r}$ & & $-\dot{M}_{f}$ & & $-\dot{D}$ & 0 \\
-Dívida & $+\dot{D}$ & & & & & 0 & 0
\end{tabular}

\subsection{Produção e firmas}

O produto desta economia é dado pela seguinte função de produção para o produto total $Y$ seguindo Setterfield e Kim (2016) e Setterfield, Kim e Rees (2016):

$$
Y=\min (v K, \quad \min (L, G / \alpha))
$$

Onde $K$ é o estoque de capital, $L$ é o número de trabalhadores e $G$ o de gerentes. Assume-se que estes últimos ganham um prêmio $\phi$ sobre o salário dos demais trabalhadores, e que a relação entre o número de trabalhadores e gerentes é dado pelo coeficiente $\alpha$.

$$
\begin{array}{r}
W_{g}=\phi W_{L}, \quad \phi>1 \\
G=\alpha L, \quad \alpha<1
\end{array}
$$

A renda total do trabalho pode então ser expressa como:

$$
W_{t}=W_{l} L+W_{g} G=W_{L} L(1+\phi \alpha)
$$


O nível de preço, $P$ segue a tradição Kaleckiana onde é definido como um mark up, $\epsilon$, sobre o custo unitário do trabalho. A distribuição funcional da renda é portanto exogenamente determinada pelo grau de monopólio da economia.

$$
\begin{array}{r}
P=(1+\epsilon) W_{t} / Y \\
\frac{W_{t}}{P Y}=\frac{1}{1+\epsilon}
\end{array}
$$

A parcela de lucros na renda é, portanto:

$$
\pi=1-\frac{W_{t}}{P Y}=\frac{\epsilon}{1+\epsilon}
$$

E a renda total da economia segundo a distribuição funcional é alocada como:

$$
\begin{gathered}
Y=W_{t}+\Pi=W_{L} L(1+\phi \alpha)+\pi Y \\
Y(1-\pi)=W_{L} L(1+\phi \alpha)
\end{gathered}
$$

A partir disso, a parcela de salários apropriada por ricos, $\omega_{r}$, e pobres, $\omega_{p}$, pode ser expressa como:

$$
\begin{gathered}
\omega_{p}=\frac{W_{L} L}{Y}=\frac{1-\pi}{1+\phi \alpha} \\
\omega_{r}=\frac{W_{L} L \phi \alpha}{Y}=\frac{(1-\pi) \phi \alpha}{1+\phi \alpha}
\end{gathered}
$$

Tabela 2 - Derivadas de $\omega_{r}$ e $\omega_{p}$

\begin{tabular}{ccccc}
\multicolumn{2}{c}{$\omega_{r}$} & \multicolumn{2}{c}{$\omega_{p}$} \\
\hline \hline$\alpha$ & $\frac{\phi(1-\pi)}{(1+\phi \alpha)^{2}}$ & + & $\frac{-\phi(1-\pi)}{(1+\phi \alpha)^{2}}$ & - \\
$\phi$ & $\frac{\alpha(1-\pi)}{(1+\phi \alpha)^{2}}$ & + & $\frac{-\alpha(1-\pi)}{(1+\phi \alpha)^{2}}$ & - \\
$\pi$ & $-\frac{\alpha \phi}{1+\phi \alpha}$ & - & $\frac{-1}{1+\phi \alpha}$ & -
\end{tabular}

A Tabela 2 relata a resposta da parcela de salários apropriada por ricos e pobres a choques em cada um dos parâmetros que as define. Os sinais são intuitivos: o alargamento 
do prêmio salarial do gerente $\phi$ e da quantidade de gerentes em relação aos demais trabalhadores, $\alpha$ elevam a parcela de renda apropriada pelos ricos, e reduzem a dos pobres. Um aumento na parcela de lucros na renda, $\pi$, reduz a parcela salarial de ambas classes.

O investimento, por sua vez, tem o formato abordado seminalmente em Rowthorn (1981), Taylor (1985) Dutt (1984), no qual é função do animal spirit dos capitalistas, $\gamma$, da taxa de lucro, $r$, e do grau de utilização da capacidade, $u$ :

$$
g^{i}=\gamma+\gamma_{u} u+\gamma_{r} r
$$

A taxa de lucro é a razão entre a massa de lucros e o estoque do capital. Pode ser expressa em função do grau de utilização da capacidade, $\left(u=Y / Y^{*}\right)$, da distribuição funcional da renda $(\pi=\Pi / Y)$, e da razão capital produto $(v=K / Y)$, multiplicandose o numerador e denominador desta fração pelo produto potencial, $Y^{*}$ e realizando-se manipulações algébricas.

$$
\begin{gathered}
r=\frac{\Pi}{K}=\frac{\pi Y}{K} \frac{Y^{*}}{Y^{*}}=\pi \frac{Y}{Y^{*}} \frac{K}{Y} \\
r=\frac{u \pi}{v}
\end{gathered}
$$

A fim de facilitar a exposição do modelo, assume-se daqui para frente que a razão capital produto, $v$ é igual à unidade.

\subsubsection{Consumo dos ricos versus pobres}

A base da pirâmide distributiva formada por trabalhadores "pobres", $L$, recebe salários nominais $W_{L}$ e consome toda sua renda disponível do trabalho, $W_{L} L$. Toma emprestado $\dot{D}$ para financiar o resto de seu consumo desejado, e paga a taxa de juros nominal $i$ de serviço sobre seu estoque de dívida acumulada. Sua renda disponível, $y_{p}$, é, portanto,

$$
\begin{aligned}
& \frac{Y_{p}}{Y}=\frac{W_{L} L-i D}{Y} \\
& y_{p}=\omega_{p}-i D / Y
\end{aligned}
$$

A escolha do nível desejado de empréstimo segue Dutt (2006), no qual existe um coeficiente $\beta$ que reflete a razão endividamento em relação a renda disponível que será 
mantida em todos os períodos. Esta estrutura assume que ou o trabalhador define o montante que quer tomar emprestado a cada período ou que existe alguma restrição de oferta imposta pelos bancos em função da renda dos trabalhadores, conforme discutido no capítulo anterior. Tal configuração é inspirada no contexto da economia brasileira no que tange ao acesso da população da base da pirâmide ao crédito. O crédito consignado, implementado em 2004, é um tipo de empréstimo que pode ser obtido junto a instituições financeiras e cujo pagamento é deduzido diretamente da folha salarial de quem o contrai; desta forma é relativamente seguro para o emprestador. O coeficiente $\beta$, ao atrelar a determinação do nível desejado de empréstimo à renda disponível das famílias pobres, pode ser interpretado como a predisposição dos bancos a emprestar em relação à renda, isto é, uma medida de oferta das instituições financeiras.

Pela ótica dos trabalhadores, a justificativa por trás do desejo de consumir além de sua renda disponível é a emulação do consumo da classe rica, conforme discutido em Barba e Pivetti (2009), Setterfield e Kim (2016), Setterfield, Kim e Rees (2016), Ryoo e Kim (2014). Optou-se por não modelar explicitamente este componente no consumo, pois não configura elemento crucial para os fins do modelo, que é a relação dinâmica entre dívida e distribuição pessoal, e sua ausência facilita a exposição. O resultado geralmente encontrado nestes modelos, de relação positiva entre consumo dos ricos e consumo dos pobres devido a emulação, não deverá ser verificado aqui pela hipótese de $\beta$ constante. A emulação é importante apenas para justificar o desejo de se endividar das famílias pobres. Portanto, seguindo Dutt (2006), os trabalhadores pobres desejam aproximar seu consumo ao da classe rica, e o fazem a cada período segundo o coeficiente $\beta$ que neste modelo representa a limitação de oferta imposta pelos bancos.

$$
\begin{gathered}
C_{p}=W_{l} L-i D+\dot{D} \\
\dot{D}=\beta\left(W_{L} L-i D\right)
\end{gathered}
$$

A classe rica, por sua vez, possui renda híbrida formada pelos salários elevados dos gerentes, $W_{g} G$, a parte do lucro distribuído das firmas, $\tau \Pi$, e o lucro dos bancos associado à provisão do crédito, $i D$. A parcela de renda disponível em relação á renda total, $y_{r}$, da classe rica será:

$$
\begin{aligned}
& \frac{Y_{r}}{Y}=\frac{W_{g} G+\tau \Pi+i D}{Y} \\
& y_{r}=\omega_{r}+\tau \pi+i D / Y
\end{aligned}
$$

Consome uma fração $c_{\pi}$ de sua renda, e aloca a poupança na compra de ações da firma e em depósitos no banco. Sua função consumo será: 


$$
C_{r}=c_{\pi}\left(W_{g} G+\tau \pi Y+i D\right)
$$

Observe que está implícita aqui a hipótese de que os ricos não têm propensão a consumir dos depósitos provenientes de poupança mantidos no banco, que podem ser considerados riqueza. Esta hipótese, apesar de não verificada empiricamente, foi assumida a fim de simplificar a exposição e segue Setterfield e Kim (2016) e Setterfield, Kim e Rees (2016).

\subsection{Equilíbrio no Curto Prazo}

Para caracterizar a solução de curto prazo do modelo parte-se do equilíbrio no mercado de bens, em que o produto é definido pela demanda efetiva, isto é, igual à soma de consumo e investimento. O preço dos bens de capital será o mesmo que os preços dos demais bens $\left(P_{K}=P_{Y}=P\right)$. Como o objetivo é analisar os determinantes do grau de utilização a partir da distribuição da renda, é necessário definir todas as variáveis em função do estoque de capital da economia (assim chega-se ao grau de utilização da capacidade, $u=Y / K)$. Portanto todos os componentes da demanda serão normalizadas em $K$. De (2.14) e (2.15), e denominando a razão estoque da dívida capital de $d=D / K$, o consumo da classe pobre normalizado pelo estoque de capital pode ser reescrito como:

$$
\frac{C_{p}}{K}=(1+\beta)\left(\frac{1-\pi}{1+\phi \alpha} u-i d\right)
$$

E de (2.17), o consumo da classe rica como:

$$
\frac{C_{r}}{K}=c_{\pi}\left(\frac{\phi \alpha(1-\pi)}{1+\phi \alpha} u+\pi \tau u+i d\right)
$$

O grau de utilização no curto prazo será definido por:

$$
\begin{gathered}
u^{*}=\frac{Y}{K}=\frac{C}{K}+\frac{I}{K} \\
u^{*}=\frac{\gamma-i d\left(1+\beta-c_{\pi}\right)}{1-c_{\pi} \omega_{r}-(1+\beta) \omega_{p}-c_{\pi} \tau \pi-\left(\gamma_{r} \pi+\gamma_{u}\right)}
\end{gathered}
$$

Rearranjando e substituindo $1-c_{\pi}=s_{\pi}$, o seguinte equilíbrio é válido no curto prazo: 


$$
\begin{gathered}
u^{*}=\frac{\gamma-i d\left(s_{\pi}+\beta\right)}{s_{\pi}\left(\omega_{r}+\pi \tau\right)-\beta \omega_{p}+(1-\tau) \pi-\left(\gamma_{r} \pi+\gamma_{u}\right)} \\
r^{*}=\pi \frac{\gamma-i d\left(s_{\pi}+\beta\right)}{s_{\pi}\left(\omega_{r}+\pi \tau\right)-\beta \omega_{p}+(1-\tau) \pi-\left(\gamma_{r} \pi+\gamma_{u}\right)} \\
g^{*}=\gamma+\left(\gamma_{u}+\gamma_{r} \pi\right) \frac{\gamma-i d\left(s_{\pi}+\beta\right)}{s_{\pi}\left(\omega_{r}+\pi \tau\right)-\beta \omega_{p}+(1-\tau) \pi-\left(\gamma_{r} \pi+\gamma_{u}\right)}
\end{gathered}
$$

A condição de estabilidade Keynesiana requer que o multiplicador, $1 / \Delta$ (sendo $\Delta$ o denominador de $u^{*}$ ), seja positivo, isto é, que a sensibilidade da poupança da economia a variações no grau de utilização supere a sensibilidade do investimento ao mesmo parâmetro:

$$
\begin{aligned}
\frac{\partial g^{s}}{\partial u}=s_{\pi}\left(\omega_{r}+\pi \tau\right)-\beta \omega_{p}+\pi(1-\tau) & > \\
\frac{\partial g^{i}}{\partial u} & =\gamma_{r}+\gamma_{u} \\
\Delta & >0
\end{aligned}
$$

Observe que o termo $s_{\pi}\left(\omega_{r}+\tau \pi\right)$ representa o incremento na poupança da classe rica a partir de um aumento de demanda, e o termo $\beta \omega_{p}$ representa a variação na despoupança da classe pobre a partir de aumentos no grau de utilização. O termo $(1-\tau) \pi$ representa a fração dos lucros retidos pelas firmas que é usado ex post para financiar o investimento, portanto, também pode ser interpretado como incremento de poupança. Outra condição para que o equilíbrio faça sentido econômico é que o numerador tenha sinal positivo: o fluxo de transferência de renda do pagamento do serviço da dívida da classe pobre para a classe rica deve ser menor que a taxa de acumulação de capital autônoma, conforme $(2.24)$.

$$
\gamma>i d\left(s_{\pi}+\beta\right)
$$

A Tabela 3 apresenta as derivadas parciais do grau de utilização em relação aos parâmetros do modelo e seus sinais. As derivadas da parcela de salários dos ricos e pobres em relação a $\pi$ estão representadas por $\omega_{r \pi}$ e $\omega_{p \pi}$, respectivamente, para simplificar a exposição. 
Assim como em Dutt (2006), o efeito de aumentar a razão de empréstimo desejado em relação à renda disponível da classe pobre é de estimular a demanda efetiva no curto prazo pelo efeito potencializador do consumo. Isto ocorre, pela definição do coeficiente $\beta$, entre 0 e 1 , que leva em conta o pagamento do serviço da dívida, garantindo que sua renda disponível sempre será maior que a dívida contraída.

O aumento na razão dívida capital, entretanto, vai no sentido contrário, uma vez que aumenta o fluxo de renda transferido dos trabalhadores pobres aos ricos devido ao pagamento de juros. Como este último só consome parte da sua renda, enquanto o primeiro consome além dela, o resultado final é que a transferência de renda reduz o grau de utilização da capacidade. A mesma intuição é válida para choques na taxa de juros que incide sobre a dívida, já que encarece seu serviço concentrando a renda a favor dos ricos. O efeito da elevação da parcela de lucros distribuídos, $\tau$, sobre $u$ é positivo, pois eleva o consumo da classe rica, sem alterar o dos pobres.

Tabela 3 - Derivadas parciais de $u^{*}$ no equilíbrio

\begin{tabular}{lll}
\hline & $u^{*}$ & \\
\hline$\beta$ & $\frac{\omega_{p} u-i d}{\Delta}$ & + \\
$\phi$ & $\frac{-u^{*} \alpha \omega_{p}\left(s_{\pi}+\beta\right)}{\Delta(1+\phi \alpha)}$ & - \\
$\pi$ & $\frac{u^{*}}{\Delta}\left[\gamma_{r}+\tau\left(1-s_{\pi}\right)-\beta \omega_{p \pi}-\left(1-s_{\pi} \omega_{r \pi}\right)\right]$ & + ou - \\
$\pi$ & $\frac{u^{*}}{\Delta}\left[\gamma_{r}-c_{\pi}(1-\tau)-\left(1+\beta-c_{\pi}\right) /(1+\phi \alpha)\right]$ & + ou - \\
$d$ & $\frac{-i\left(s_{\pi}+\beta\right)}{\Delta}$ & - \\
$i$ & $\frac{-d\left(s_{\pi}+\beta\right)}{\Delta}$ & - \\
$\alpha$ & $\frac{-u^{*} \phi \omega_{p}\left(s_{\pi}+\beta\right)}{\Delta(1+\phi \alpha)}$ & - \\
$\tau$ & $\frac{u^{*}}{\Delta} \pi\left(1-s_{\pi}\right)$ & +
\end{tabular}

Em relação à distribuição de renda, uma elevação no prêmio de salário do gerente em relação ao do trabalhador, $\phi$, contrai a demanda efetiva. Os gerentes e capitalistas só consomem parte da renda enquanto os trabalhadores a consomem toda, portanto, a concentração da distribuição salarial implica um vazamento de demanda via poupança. O mesmo raciocínio é válido para choques em $\alpha$, isto é, a elevação do número de gerentes em relação aos trabalhadores, também concentra renda e acarreta vazamento de demanda de consumo.

O resultado negativo não se sustenta quando se avalia a distribuição funcional; redistribuições a favor de lucros podem ter efeito expansionista ou contracionista na demanda efetiva, a depender da magnitude da sensibilidade da função investimento à variável lucratividade em face à redução do consumo.

$$
\frac{\partial u}{\partial \pi}>0 \quad \leftrightarrow \quad \gamma_{r}>c_{\pi}(1-\tau)+\frac{(1+\beta)-c_{\pi}}{1+\phi \alpha}
$$


A equação (2.25) compara os efeitos investimento (lado direito) e consumo (esquerdo) dos ricos e pobres a partir de um aumento da participação dos lucros na renda. O efeito lucratividade sobre a função investimento é positivo e representado por $\gamma_{r}$.

O efeito no consumo do lado direito da equação é definido por dois componentes. O primeiro, $c_{\pi}(1-\tau)$, é a compressão no consumo dos ricos devido à elevação na parcela de lucros retidos nas firmas, que o aumento de $\pi$ ocasiona.

O segundo é o tradicional efeito Kaleckiano de transferência de renda da classe que não poupa para a que poupa. Este efeito fica evidente pelo termo $\frac{(1+\beta)-c_{\pi}}{1+\phi \alpha}$ que mostra a diferença entre a propensão a consumir dos pobres, $1+\beta$ e dos ricos, $c_{\pi}$, descontado pelo denominador da renda híbrida da economia. Portanto, o aumento da participação dos lucros na renda deprime o consumo pela maior retenção de lucros nas firmas e pela concentração de renda a favor da classe que possui propensão a poupar positiva.

Observe, contudo, que neste modelo a hipótese de renda híbrida dos ricos cria a possibilidade do consumo da classe não aumentar a partir de redistribuições a favor dos lucros. A derivada da renda disponível dos ricos em relação à parcela de lucros na renda é:

$$
\frac{\partial y_{r}}{\partial \pi}=\tau-\frac{\phi \alpha}{1+\phi \alpha}
$$

Se o incremento dos lucros distribuídos repassados aos ricos, $\tau$, supera a redução no salário dos executivos ou gerentes, $\phi \alpha /(1+\phi \alpha)$ o consumo da classe aumenta em $c_{\pi}$, caso comumente observado nos modelos Kaleckianos sem renda híbrida. Note que este incremento de consumo dos ricos é sempre inferior à queda no consumo dos pobres, uma vez que os últimos consomem além da sua renda

Por outro lado, o consumo dos ricos pode diminuir se a taxa de retenção de lucros da firma for muito alta $-\tau$ baixo -, e a redistribuição a favor dos lucros comprimir a renda disponível da classe. Este cenário ocorre quando $\tau<\phi \alpha /(1+\phi \alpha)$, e fortalece a tendência wage-led do regime de demanda. A compressão no consumo seria decorrente não só da transferência dos que não poupam para os que poupam, mas também do encolhimento da renda disponível das duas classes.

A comparação de tal resultado com o do modelo neo-Kaleckiano canônico não oferece relação clara sobre o fortalecimento da tendência wage ou profit-led. Primeiro, como em grande parte dos modelos com crédito, a presença de endividamento potencializa o efeito consumo de redistribuições a favor da renda do salário, uma vez que $1+\beta-c_{\pi}>$ $1-c_{\pi}$. No entanto, verifica-se o enfraquecimento do efeito de redistribuições a favor dos salários, já que parte dele está em posse da classe rica e é poupada. O efeito de redistribuições a favor dos lucros sobre o consumo também é amortizado, já que parte dos lucros não é distribuída á classe rica. O resultado dependerá da magnitude de $c_{\pi}$ em 
relação aos parâmetros do modelo, conforme:

$$
\begin{gathered}
\frac{\partial u}{\partial \pi} \gtrless \frac{\partial u}{\partial \pi} \text { tradicional } \\
\gamma_{r}-\left[c_{\pi}(1-\tau)-\frac{(1+\beta)-c_{\pi}}{1+\alpha \phi}\right] \gtrless \gamma_{r}-s_{\pi} \\
c_{\pi} \gtrless \frac{\phi \alpha-\beta}{\phi \alpha+(1+\phi \alpha)(1-\tau)}
\end{gathered}
$$

Dependendo da magnitude de $c_{\pi}$ o regime de demanda deste modelo pode ficar mais ou menos profit-led. Quanto maior a propensão a consumir da classe rica, maior a chance tendência wage-led ser reforçada neste modelo. Em outras palavras, quanto menor a propensão a poupar da classe rica, mais devastador é o efeito de se concentrar renda a favor dos lucros sobre a demanda desta economia,tornando menos provável que o efeito investimento compense o efeito consumo.

\subsection{Médio prazo}

O objetivo da análise de médio prazo é avaliar o que ocorre quando se permite que a distribuição funcional da renda e o estoque da dívida variem. A novidade neste modelo é que a distribuição intrasalarial da renda medida pelo prêmio salarial dos gerentes, $\phi$, influencia a dinâmica de médio prazo das duas variáveis.

\subsubsection{Dinâmica de médio prazo da dívida}

A equação de movimento da dívida é definida da seguinte forma:

$$
d=\frac{D}{K} \quad \leftrightarrow \quad \hat{d}=\hat{D}-\hat{K}
$$

A trajetória de médio prazo da dívida depende de como seu estoque $D$ evolui em relação ao estoque de capital da economia $K$. Substituindo $\hat{D}$ por $\dot{D} / D$ e $\hat{K}$ por $g_{k}$, chega-se à seguinte equação de movimento em função dos parâmetros do modelo:

$$
\begin{gathered}
\hat{d}=\frac{\beta(1-\pi) u}{d(1+\phi \alpha)}-i-\left(\gamma+\gamma_{u} u+\gamma_{r} r\right) \\
\dot{d}=\frac{\beta(1-\pi) u}{(1+\phi \alpha)}-i d-\gamma d-\left(\gamma_{r} \pi+\gamma_{u}\right) u d
\end{gathered}
$$


Figura 2 - Curva $\dot{d}=0$

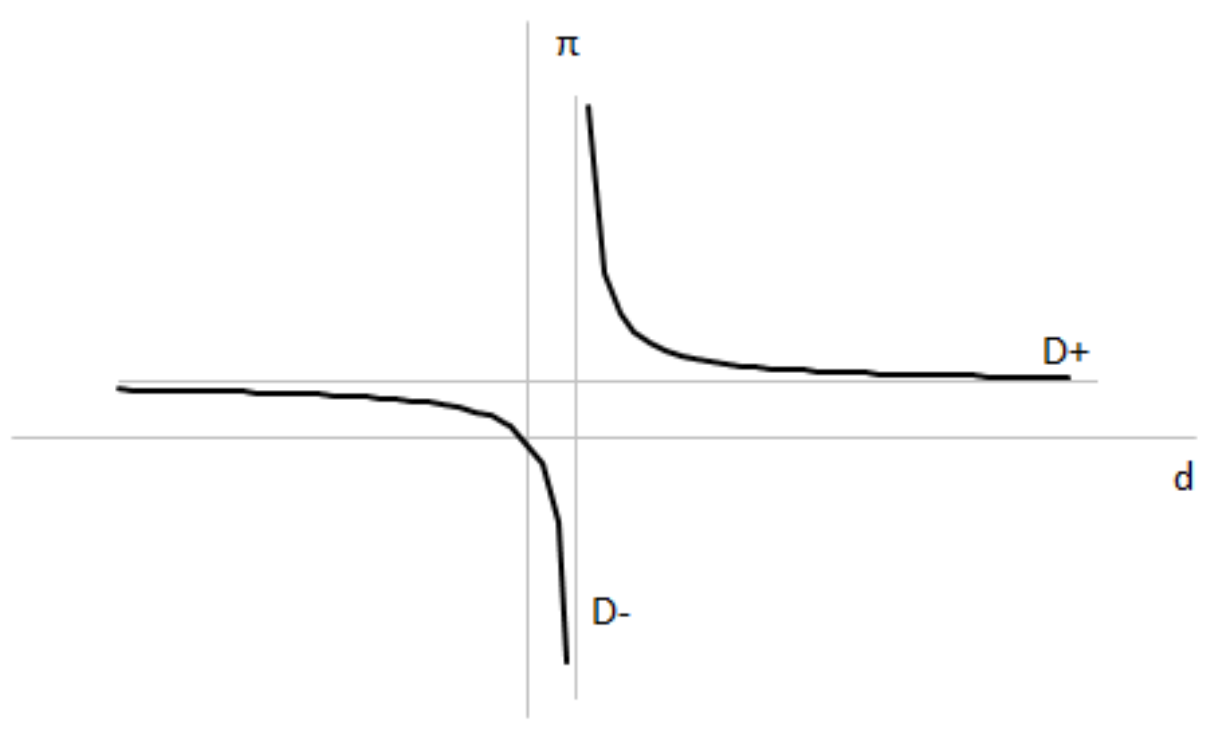

O equilíbrio de médio prazo de $d$ se dará nos pontos nos quais essas duas taxas de crescimento se equivalem e a dívida não varia, isto é $\dot{d}=0$. Este lócus de pontos está plotado na Figura 2 e tem a forma funcional de uma hipérbole. A análise deste equilíbrio só faz sentido econômico na curva $D+$ no quadrante positivo, caso contrário, o equilíbrio seria caracterizado de valores negativos para a dívida e a parcela de lucros na renda.

\subsubsection{Dinâmica de médio prazo da distribuição da renda}

Quanto à dinâmica da distribuição funcional, a hipótese de exogeneidade desta variável no médio prazo é relaxada; $\pi$ será determinada endogenamente pelo prêmio salarial, $\phi$, e pelo grau de utilização, $u$ - que indiretamente proporcionará uma relação entre esta variável e a razão dívida-capital, $d$. Modelar a relação de médio prazo entre distribuição pessoal, funcional e grau de utilização não é novidade em modelos Kaleckianos.

Tavani e Vasudevan (2014), por exemplo, apresentam uma dinâmica distributiva de médio prazo de compressão salarial, na qual capitalistas e gerentes têm interesses em comum na disputa por renda: acréscimos no salário dos gerentes em relação ao dos trabalhadores melhoram a fiscalização do trabalho, elevando a produtividade da economia. O desdobramento disto sobre a demanda é que o aumento do prêmio salarial eleva o grau de utilização da economia independentemente de regime de demanda ser profit ou wageled, ou seja, o regime de demanda é inequality-led quanto à dispersão salarial. Em outras palavras, na medida em que aumenta a produtividade dos trabalhadores, a concentração salarial gera produção e renda, que não é repassada aos trabalhadores na forma de maior remuneração, portanto redistribuições a favor dos gerentes também proporcionam acréscimos de lucros. Neste modelo as duas formas de se concentrar renda possuem trajetória conjunta e se reforçam. 
Já Palley (2013) inspirado na literatura de ciclos de Goodwin (1967) modela tal relação de forma contrária: quanto mais aquecido o mercado de trabalho, maior a demanda por mão-de-obra e maior o poder de barganha dos trabalhadores frente a gerentes na disputa distributiva. Redistribuições a favor dos trabalhadores são decorrentes do aumento do produto total da economia, isto é, a relação entre distribuição e demanda é oposta à de Tavani e Vasudevan (2014). Observe que o canal de causalidade também é contrário, uma vez que Palley (2013) está analisando como a demanda afeta a distribuição, ao invés de como a distribuição afeta a demanda.

Uma análise inspirada nestas duas abordagens será considerada aqui. A equação de movimento para $\pi$ parte da ideia que classe rica possui mais poder institucional que os pobres e persegue uma meta $\pi_{T}$ a cada período. A relação entre $\pi_{T}$ e $u$ será negativa, seguindo Palley (2013): quanto maior $u$, mais aquecido o mercado de trabalho e maior o poder de barganha de todos os trabalhadores ${ }^{2}$, seguindo o formato profit squeeze dos ciclos de Goodwin (1967). Pode-se também enxergar tal relação pelo lado da demanda da classe rica: quanto maior o grau de utilização e maior a renda da economia, menor a tensão distributiva, o que relaxa a meta para os lucros.

A partir desta hipótese, uma relação indireta entre endividamento e distribuição funcional é obtida. Um aumento no estoque da dívida ao reduzir o grau de utilização de curto prazo, conforme exposto na tabela 3 , pressiona indiretamente a parcela de lucros para cima por desaquecer o mercado de trabalho, tornando o efeito de $d$ sobre $\pi$ positivo.

$$
\uparrow d \quad \downarrow u \quad \uparrow \pi
$$

A relação entre parcela de lucros na renda e o prêmio salarial, $\phi$, dos gerentes será determinada por dois fatores. O primeiro é o efeito direto entre as duas variáveis discutido em Tavani e Vasudevan (2014) no qual $\phi$ e $\pi$ caminham juntos por gerentes possuírem maior incentivo a fiscalizar melhor o trabalho e, portanto, extrair níveis maiores de produtividade dos trabalhadores, quando são melhor remunerados. Desta forma, quanto maior o prêmio salarial, também maior o lucro da firma. O segundo canal de influência de se dá através do grau de utilização: o aumento do prêmio salarial dos gerentes, ao reduzir $u$ de curto prazo pelo efeito depreciativo no consumo trabalhadores pobres (Tabela 3), aumentaria a parcela de lucros na renda $\pi$ por desaquecer o mercado de trabalho - efeito Goodwin (1967).

Observe que os dois efeitos se complementam: o aumento do prêmio salarial eleva a produtividade de alguns trabalhadores e concomitantemente reduz o consumo da classe, por contrair sua renda disponível. O impacto sobre a demanda é de reduzir a produção total, ocasionar demissões e desaquecer o mercado de trabalho, com a produtividade em

2 Diferentemente de Palley (2013), o conflito distributivo neste modelo se dá no âmbito salário total versus lucros ao invés de salários dos gerentes frente a salário dos trabalhadores, como ele supunha. 
patamar superior ao inicial. O resultado final é que a concentração a favor dos gerentes redistribui a repartição funcional da renda a favor dos lucros. Para a análise de estática comparativa, a hipótese é que $\phi$ influencia apenas o intercepto da curva $\dot{\pi}=0$.

$$
\uparrow \phi \quad \uparrow \pi
$$

A equação (2.29) representa o lucro desejado (target profit share), $\pi^{T}$ em função de $u, d$ e $\phi$. O efeito das três variáveis em $\pi$ é por hipótese marginalmente decrescente a fim de evitar trajetórias explosivas de $\pi_{T}$ - a segunda derivada destes parâmetros negativa.

$$
\begin{gathered}
\dot{\pi}=\pi^{T}-\pi=f(u, \phi)-\pi \\
\dot{\pi}=\pi^{T}-\pi=f(u(d), \phi)-\pi \\
f^{\prime}(u)<0, \quad f^{\prime}(\phi)>0, \quad f^{\prime}(d)>0, \quad f^{\prime \prime}(u, \phi)<0 \\
\pi^{T}>\pi \quad \rightarrow \quad \dot{\pi}>0
\end{gathered}
$$

\subsubsection{Equilíbrio}

Figura 3 - Equilíbrio

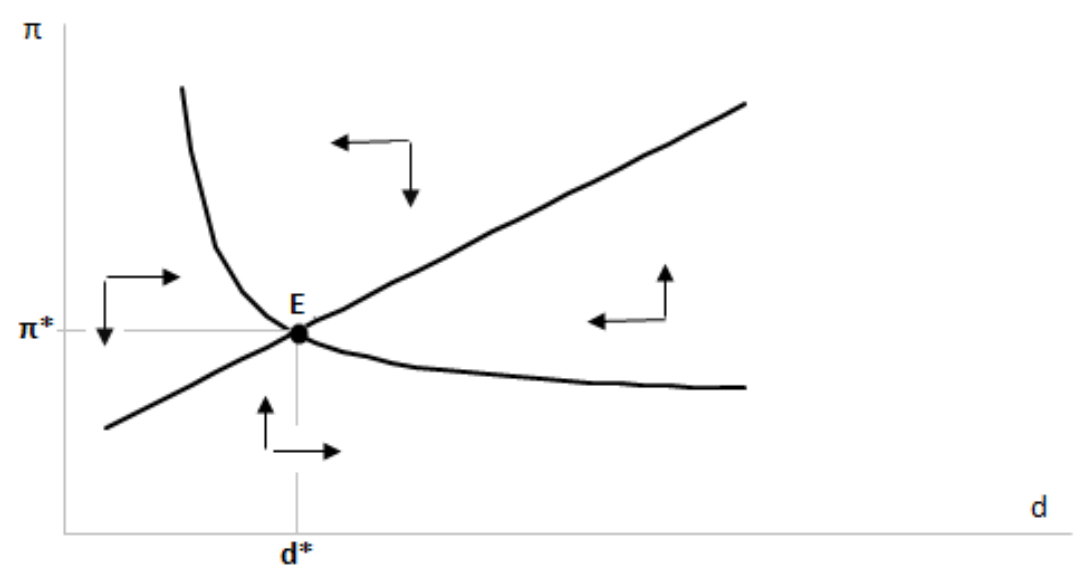

O equilíbrio de médio prazo é definido pela interseção das curvas $\dot{d}=0$ e $\dot{\pi}=0$ no plano $\pi \quad x \quad d$. O lócus de pontos no qual a dívida é estável tem inclinação negativa, enquanto o lócus de pontos no qual a parcela de lucros não varia é positivo. A análise de estabilidade é desenvolvida no Apêndice A e contrapõe os efeitos direto e cruzado de uma variável endógena sobre outra. A estabilidade da dívida $d=D / K$ está sujeita aos efeitos que $d$ e $\pi$ exercem sobre $D$ e $K$. Para que $d$ possua dinâmica estável, o endividamento deve reagir menos a choques nele próprio do que o estoque de capital, segundo a função para sua taxa de acumulação, o investimento. A estabilidade da parcela de lucros na renda é garantida pela hipótese de segunda derivada negativa por trás de sua função 
comportamental. A estabilidade conjunta do sistema é sujeita às influências cruzadas e depende, dentre outros fatores, da natureza do regime de demanda. Conforme é indicado no apêndice, a instabilidade é um cenário possível, porém menos provável, por isso a análise de estática comparativa se concentrará no caso estável. A Figura 3 plota as curvas no plano cartesiano.

$$
\begin{gathered}
\dot{d}=\frac{\beta(1-\pi) u}{(1+\phi \alpha)}-i d-\gamma d-\left(\gamma_{r} \pi+\gamma_{u}\right) u d=0 \\
\dot{\pi}=f(u(d), \phi)-\pi=0
\end{gathered}
$$

A análise de estática comparativa leva em conta o que ocorre com o equilíbrio a partir de choques nos parâmetros, particularmente na distribuição intrasalarial, medida pelo parâmetro de prêmio dos salários, $\phi$.

A concentração de renda dos salários a favor dos gerentes desloca ambas curvas $\dot{\pi}=0$ e $\dot{d}=0$ para a esquerda. O efeito sobre a curva de dívida se justifica pela equação comportamental para a variação dos empréstimos, $\dot{D}$, ser atrelada à renda disponível dos pobres. A concentração salarial no topo da distribuição acarreta que uma mesma parcela salarial na renda esteja associada a uma renda disponível dos pobres inferior, o que, por sua vez, reduz a contratação de novos empréstimos.

O efeito sobre a curva distributiva, por sua vez, é decorrente dos dois efeitos discutidos na seção anterior de $\phi$ sobre a parcela de lucros; o direto ligado a produtividade, inspirado em Tavani e Vasudevan (2014) e o indireto via grau de utilização, relacionado ao efeito Goodwin (1982). A concentração de renda a favor dos gerentes (i) melhora a fiscalização do trabalho; (ii) reduz o consumo da classe pobre; (iii) reduz o grau de utilização; (iv) desaquece o mercado de trabalho. O resultado é menos trabalhadores empregados, mas maior produtividade dos que mantiveram seus postos. Portanto são duas vias pelas quais um mesmo estoque de dívida permite uma parcela de lucros na renda superior: pela maior produtividade dos trabalhadores empregados sem que este ganho seja repassado à classe na forma de salários; e o aumento do desemprego no mercado de trabalho que diminui o poder de barganha por salários dos trabalhadores, redistribuindo a favor do lucro da classe rica.

O resultado é que a concentração a favor dos gerentes eleva ${ }^{3}$ a parcela de lucros na renda e reduz estoque da dívida, como fica evidente na Figura 4

Observe que este resultado consegue apenas parcialmente reproduzir a dinâmica entre parcela de lucro na renda, distribuição funcional e estoque de dívida observada em

3 A depender do deslocamento da curva $\dot{d}=0$, a parcela de lucros na renda também poderia cair, entretanto simulações matemáticas mostraram que esta curva é pouco sensível a choque em $\phi$, tornando o efeito de alargamento de $\pi$ dominante. 
Figura 4 - Choque positivo em $\phi$

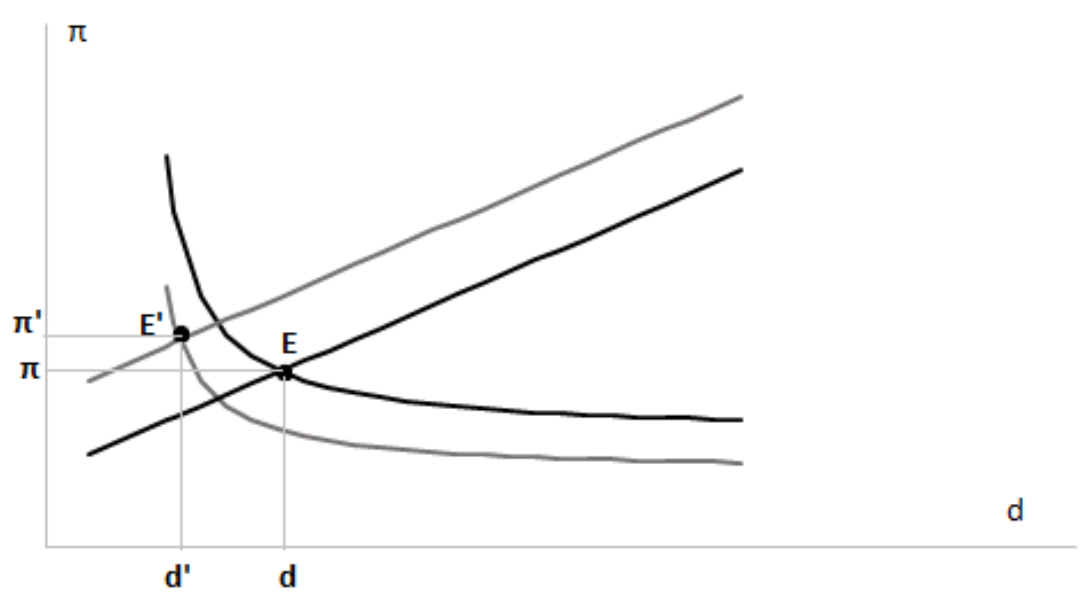

economias avançadas. Se por um lado, a concentração na renda dos salários também eleva a concentração dos lucros em linha com as evidências empíricas, por outro, acarreta, segundo este modelo, um estoque de dívida de médio prazo menor. Não reproduz a relação negativa observada nos países ricos em que $d$ cresce justamente para compensar a estagnação no crescimento da renda da população mais pobre a fim de manter os padrões consumo. Este resultado é decorrente da forma como a equação comportamental para os empréstimos foi modelada, na qual taxa a acumulação de dívida é proporcional à renda disponível dos pobres.

Contudo, a estrutura do modelo parece adequada para modelar a dinâmica de países emergentes: no caso brasileiro, o estoque $d$ passa a ter trajetória ascendente justamente quando a renda disponível dos pobres começa a crescer. Para ilustrar este caso a Figura 5 mostra a reação das variáveis a um choque negativo em $\phi$.

O resultado sobre o equilíbrio é de elevar o estoque da dívida e de reduzir a parcela de lucros na renda. Neste caso, a desconcentração dos salários na renda aumenta a renda disponíveis dos pobres, possibilitando maior acesso ao endividamento pelas famílias da base da distribuição. Concomitantemente aumenta o grau de utilização, que via efeito Goodwin (1967) sobre o mercado de trabalho eleva o poder de barganha dos trabalhadores, reduzindo a parcela de lucros na renda. Neste caso, a melhora distributiva funcional e pessoal contribui para maiores níveis de equilíbrio da dívida de médio prazo. Este resultado do modelo parece razoável para descrever economias menos desenvolvidas, nas quais o acesso ao crédito ainda é restrito pelo lado da oferta pelo baixo nível de renda de grande parte da população.

O resultado desses deslocamentos sobre o novo grau de utilização está sujeito ao regime de demanda vigente. No choque distributivo da Figura 5, se a economia é wage-led, a redução nas duas formas de concentração da renda deve elevar o grau de utilização, mas 
Figura 5 - Choque negativo em $\phi$

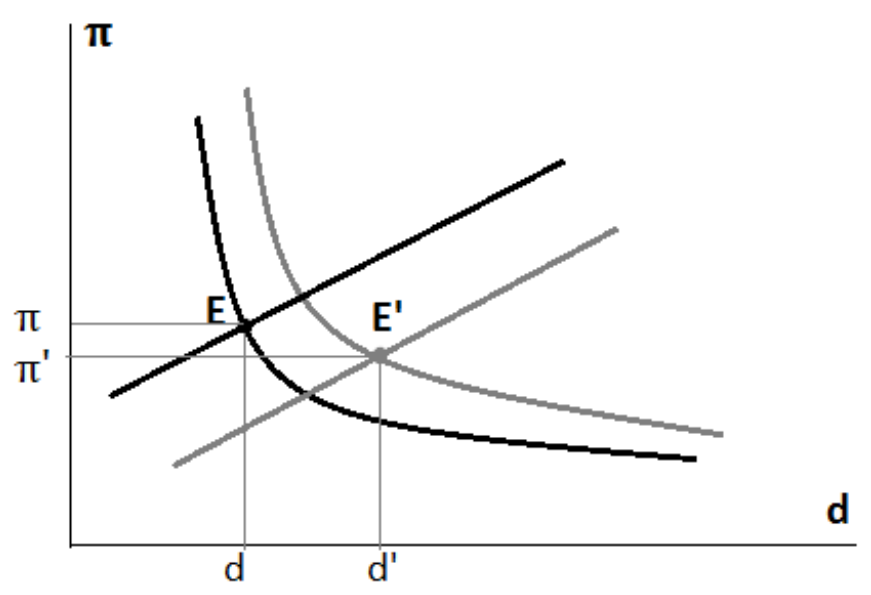

por outro lado, o aumento do estoque da dívida pode o contrair. O resultado final está sujeito à magnitude dos parâmetros do estoque da dívida, mas o efeito líquido sobre a demanda só tende a ser negativo se $d$ for muito elevado. Seria o caso quando o serviço da dívida pago pelos pobres comprometesse de tal forma sua renda disponível, que anulasse o efeito demanda positivo de desconcentrar renda em uma economia wage-led. Este cenário é tão mais plausível quanto maior a taxas de juros, $i$, que é cobrada sobre estes empréstimos. Este resultado evidencia dois fatores: (i) o caráter duplo do endividamento de, por um lado, alavancar a demanda efetiva no curto prazo, mas por outro não configurar uma fonte sustentável para acréscimos de demanda no médio; e (ii) o potencial limitado de melhoras distributivas ampliarem a demanda, uma vez que neste modelo ampliam também a dívida contraída, comprometendo parte da renda disponível dos pobres num horizonte temporal mais longínquo, especialmente em economias cujas taxa de juros de equilíbrio são altas.

O impacto sobre a demanda em uma economia profit-led a partir do choque da Figura 5 seria mais devastador ainda: o efeito dívida negativo seria exacerbado pelo efeito da redução nos lucros sobre o regime de demanda. Por outro lado, se o choque no prêmio salarial, $\phi$, fosse positivo, conforme a Figura 4, os dois efeitos finais sobre o regime de demanda se reforçariam. O aumento na participação dos lucros e a redução no estoque da dívida de médio prazo, neste caso, alargariam o grau de utilização, cenário do tipo inequality led semelhante ao de Tavani e Vasudevan (2014), no qual a concentração salarial e funcional da renda associa-se a incrementos de demanda.

A análise sobre a predisposição da classe pobre a se endividar ou sobre a limitação do acesso ao crédito definido pelos bancos, parâmetro $\beta$, também é relevante. A Figura 6 mostra os deslocamentos das curvas de endividamento e distributiva a partir de um choque 
Figura 6 - Choque em $\beta$ : caso 1

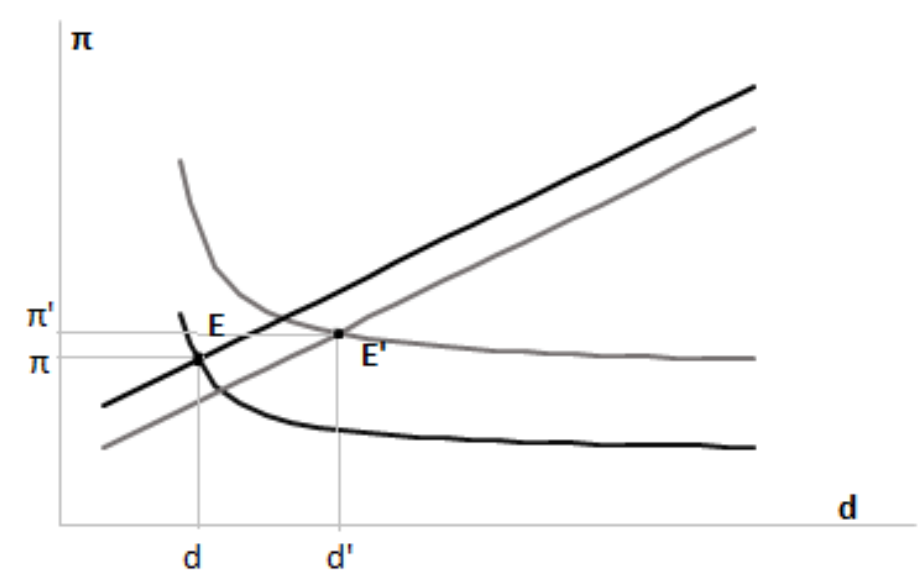

positivo em $\beta$. O aumento da predisposição dos bancos a conceder empréstimos eleva o estoque de dívida para uma mesma participação dos lucros na renda, deslocando a curva $\dot{d}=0$ para a direita. Também desloca a curva $\dot{\pi}=0$ para a direita pelo efeito Goodwin indireto: ao elevar o grau de utilização de curto prazo, aquece o mercado de trabalho e reduz a participação dos lucros na renda para um mesmo estoque de dívida. Espera-se que o deslocamento da curva da dívida seja proporcionalmente superior ao deslocamento da curva distributiva, pela sua maior sensibilidade ao parâmetro de predisposição ao endividamento.

O resultado é que o choque em $\beta$ eleva tanto o estoque da dívida quanto a parcela de lucros no novo equilíbrio, conforme a Figura 6. Observe que ainda que $\beta$ tenha efeito positivo sobre o grau de utilização de curto prazo e gere algum estímulo na demanda e no mercado de trabalho, a parcela de salários na renda se reduz. Isto ocorre, pois o efeito Goodwin é neutralizado pelo maior pagamento do serviço da dívida que a elevação neste estoque para $d^{\prime}$ acarreta. A conclusão é que o efeito sempre positivo de $\beta$ sobre a demanda pode não se manter no médio prazo.

Se a economia é profit-led, a tendência é que se mantenha, já a elevação da parcela de lucros para $\pi^{\prime}$ deve contribuir para incrementar a demanda, apesar do efeito contracionista de $d^{\prime}>d$. Se é wage-led, o aumento da predisposição a se endividar é de deprimir a demanda no médio prazo, pelos dois efeitos negativos de $d$ e $\pi$ que se reforçam. Este impacto será um tanto maior quanto maior a taxa de juros de serviço da dívida e evidencia mais uma vez a limitação do endividamento em sustentar a demanda agregada no médio prazo.

A depender da magnitude dos deslocamentos das duas curvas, pode ocorrer também da dívida aumentar, mas a participação dos lucros na renda se reduzir, conforme a Figura 7. Este seria o caso se o grau utilização da economia fosse super sensível ao 
Figura 7 - Choque em $\beta$ : caso 2

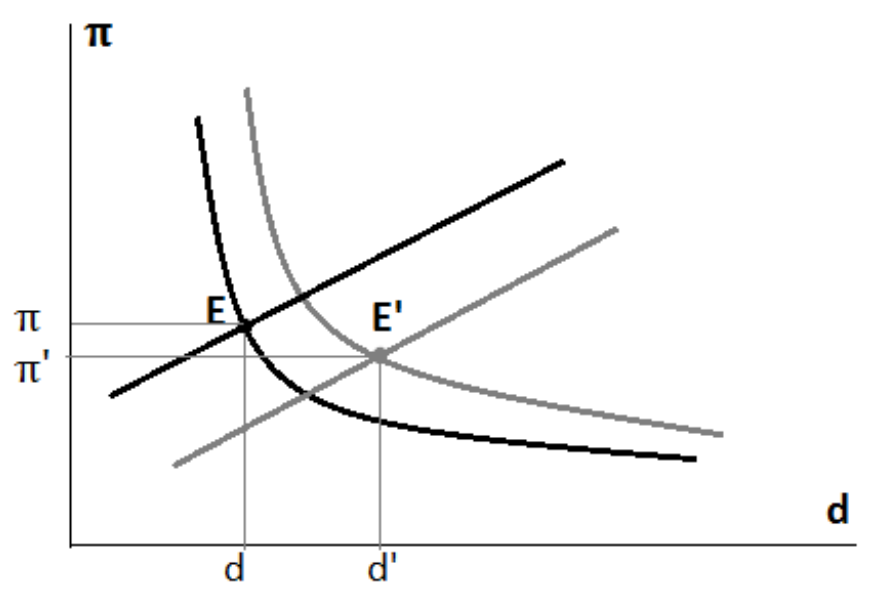

consumo dos pobres e aumentasse consideravelmente a partir de um choque em $\beta$. Tal estímulo à demanda aqueceria o mercado de trabalho e aumentaria a participação dos salários na renda pela maior barganha dos trabalhadores na disputa distributiva - efeito Goodwin (1967). Este resultado é inexistente em modelos que abordam a dívida e pode até parecer contraintuitivo. O endividamento estaria impulsionando a demanda de tal forma que elevaria o emprego e redistribuiria renda a favor dos salários. A dívida seria neste caso um mecanismo não de concentrar, mas de distribuir a renda a favor dos trabalhadores ainda que em parte aos trabalhadores ricos - pelo seu efeito sobre o mercado de trabalho.

Neste caso, a curva $\dot{\pi}=0$ deve se deslocar tanto quanto a curva $\dot{d}=0$. Se o regime de demanda é wage-led, o impacto negativo de um estoque da dívida superior ao inicial sobre a demanda poderia ser compensado pela menor participação dos lucros na renda. Se a economia é profit-led, entretanto, a maior predisposição ao endividamento apenas deprimiria a demanda pelos dois efeitos negativos se reforçando. Note que o resultado da redução na parcela de lucros a partir de choque positivo em $\beta$, é mais provável em um regime wage-led, já que a resposta do consumo á distribuição tende a ser mais relevante em economias desta natureza do que as profit-led.

\subsection{Considerações finais}

A análise dinâmica do médio prazo proporcionou resultados novos sobre a relação entre distribuição funcional, endividamento das famílias e o impacto de se concentrar ou desconcentrar salários sobre a dinâmica das duas variáveis. A relação positiva no médio prazo entre as duas medidas de distribuição - o prêmio salarial e a parcela de lucros na renda - gera dois resultados distintos sobre a demanda a depender de seu regime. 
Em economias do tipo profit-led, a concentração dos salários a favor dos gerentes eleva a parcela de lucros na renda e aumenta a demanda efetiva. Além disso, ao contrair a renda dos pobres, reduz o estoque da dívida, que também contribui no médio prazo para maiores níveis de demanda efetiva devido ao menor nível do serviço pago pelo endividamento. Quando a economia é profit-led também é inequality led quanto aos salários, o que reforça o protagonismo da concentração da renda a favor da classe rica no alcance de níveis de demanda mais altos.

Este resultado não se sustenta em um cenário do tipo wage-led. Em economias desta natureza, a desconcentração salarial não aumenta necessariamente o nível de demanda efetiva da economia, isto é, o regime pode não ser equality led. Isto ocorre, pois o efeito positivo do acréscimo de demanda devido à melhora distributiva estaria amenizado e até limitado pelo acréscimo no estoque da dívida de médio prazo, que a redução da desigualdade também acarreta. Apesar de atuar potencializando o consumo do curto prazo, o endividamento quando exacerbado compromete a renda dos pobres pelo encargo que a classe paga sobre este montante, especialmente em economias que operam com taxas de juros de equilíbrio altas. Portanto, ainda que seja provável que uma economia wage led também seja equality led, isto pode não ocorrer devido ao efeito dívida que atua contraindo a demanda.

Em resumo, pode-se concluir que em economias profit-led, choques na distribuição salarial serão mais significativos tanto em deprimir quanto em estimular a demanda efetiva do que sob regime wage-led. A correlação da renda da classe pobre com o montante que contrai de empréstimos a cada período gera este resultado: parte do impacto positivo de melhoras distributivas em economias wage-led é comprometido com acréscimo de dívida, que no médio prazo se resume a encargos mais elevados com seu serviço.

O resultado do modelo oferece uma contribuição nova para a literatura sobre a relação entre dívida e distribuição. Os demais modelos existentes replicam as observações empíricas das trajetórias da dívida e da distribuição nos Estados Unidos e na Europa, onde o endividamento cresce para compensar a estagnação na renda da base da pirâmide distributiva e manter padrões de consumo (Setterfield e Kim (2016), Setterfield (2014), Ryoo e Kim (2014), Barba e Pivetti (2009)). Diferentemente de países ricos, o acesso ao crédito em países emergentes é restrito tanto pela demanda quanto pela oferta, dado o baixo nível de renda disponível da população da base da pirâmide. Nestas economias é justamente a melhora distributiva que possibilita à classe pobre acesso ao crédito. O modelo desenvolvido neste capítulo consegue em parte replicar tal dinâmica, introduzindo uma estrutura alternativa às já existentes para tratar das particularidades do endividamento em massa e da distribuição intra-salarial. Oferece uma relação dinâmica de médio prazo entre as duas formas de medir a distribuição a partir de hipóteses sobre disputa distributiva e produtividade e evidencia o potencial dúbio da dívida de gerar acréscimos 
de demanda no curto prazo, mas de seus encargos comprometerem a renda dos pobres podendo acarretar efeito contracionista sobre a demanda. 


\section{Economia Brasileira e Econometria}

\subsection{Introdução}

A partir do arcabouço teórico Kaleckiano apresentado no primeiro capítulo e do modelo desenvolvido no capítulo anterior, este capítulo pretende analisar a relação empírica entre distribuição funcional da renda e demanda agregada para a economia brasileira entre 1995 e 2013. Conforme já discutido, os modelos Kaleckianos inspiram uma série de trabalhos empíricos, cujo objetivo é investigar o efeito de mudanças na distribuição funcional sobre o desempenho macroeconômico - medido pelo grau de utilização da capacidade - para assim definir o regime de demanda dos países. São dois os métodos empregados: o das equações individuais e o método VAR.

No primeiro, o efeito da distribuição funcional sobre cada um dos componentes da demanda (consumo, investimento e exportações líquidas) é estimado separadamente em equações lineares e o regime de demanda é definido pela soma destes efeitos. O exercício de somar coeficientes estimados separadamente e com níveis significâncias distintos é, entretanto, alvo de críticas e enfraquece a robustez do resultado final (Schoder et al. (2016)). Além disto, o método também é criticado pela suposição de exogeneidade da variável distributiva (Skott (2015), Palley (2014)) implícita em suas estimações, e pelo fato de eventualmente não incluir variáveis de controle relevantes (Palley (2014), Carvalho e Rezai (2015)).

O método VAR, por sua vez, contorna o problema da suposição de exogeneidade da variável distributiva ao estimar simultaneamente a relação entre parcela de lucros/salários e o grau de utilização. Contudo, é também alvo de críticas pelo fato de o resultado final ser sensível ao número de defasagens utilizadas (Schoder et al. (2016)) e por sua interpretação ser sinuosa, uma vez que não é possível detectar precisamente a relação entre as variáveis econômicas individualmente e a distribuição, além de não permitir a distinção entre os efeitos da demanda na economia aberta e fechada (Onaran e Galanis (2012)).

Há também críticas que podem ser endereçadas aos dois métodos quanto à relevância da própria determinação de regime de demanda de países. Contribuições recentes começam a questionar a existência de regimes de demanda estáveis, a possibilidade de quebras estruturais e de parâmetros variantes no tempo, além de dar ênfase à necessidade de se considerar extensões ao modelo convencional, fatores cruciais à robustez que, quando ignorados, devem configurar viés nas estimações (Carvalho e Rezai (2015), Palley (2014), Skott (2015), Nikiforos (2014)). Conforme argumenta Nikiforos (2014), o regime não deve ser linear e estático na variável distributiva; o horizonte temporal da análise 
também deve influenciar seu resultado (Blecker et al. (2015)); e, no âmbito normativo, a distribuição funcional não é passível de controle, tornando difícil se tirar conclusões de política econômica a partir destes resultados (Skott (2015), Schoder et al. (2016)). A mera identificação do regime de demanda sem considerar estes e outros aspectos metodológicos acarreta resultados inconclusivos e incapazes de direcionar políticas macroeconômicas.

Em linha com as ressalvas teóricas e econométricas expostas acima sobre as investigações empíricas existentes, o exercício deste capítulo não pretende definir o regime de demanda da economia brasileira. Como defendem Carvalho e Rugitsky (2015), o uso de modelos neo-Kaleckianos na compreensão de processos de desenvolvimento econômico deve ir além da concepção simplista de regimes de demanda estáveis. As particularidades dos processos de crescimento de cada país representam possíveis fontes de expansão para a literatura, uma vez que representam ponte entre a abstração matemática dos modelos e o que é observado empiricamente, permitindo a melhor compreensão dos fenômenos econômicos.

Portanto, aproveitando a conjuntura econômica nos anos 2000, o objetivo do exercício empírico do capítulo é analisar como extensões do modelo alteram a relação entre distribuição funcional da renda e demanda agregada. Três fatores relevantes para explicar o desempenho do Brasil - aumento do endividamento das famílias, redução na desigualdade intra-salarial e aumento da demanda externa por exportações nacionais - são extensões já conhecidas dos modelos Kaleckianos e foram exploradas no modelo teórico desenvolvido no capítulo anterior. A ideia aqui é incluí-las como variáveis de controle em estimações pelo método VAR, a fim de analisar como influenciam ou alteram a relação entre distribuição funcional e demanda agregada no Brasil. Desta forma, o método poderá endereçar duas críticas a que são alvo os estudos já existentes: o problema das variáveis omitidas; e a hipótese de exogeneidade da variável distributiva.

Esta análise empírica pretende contribuir para o debate teórico e empírico Kaleckiano sobre a relevância e a robustez econométrica da determinação do regime de demanda dos países e também contribuir para o debate conjuntural sobre desempenho macroeconômico da economia brasileira nos anos 2000.

O resto deste capítulo está organizado da seguinte forma. A seção 2 discute os principais fatores por trás do crescimento econômico do Brasil nos anos 2000, que motiva o exercício econométrico pretendido. Na seção seguinte, os dados que serão utilizados no exercício econométrico são apresentados e a metodologia usada para construir a série de distribuição funcional trimestral apresentada. Na seção 4, o método VAR é explicado, seguido do resultado e das considerações finais nas seções seguintes. 


\subsection{Economia Brasileira}

A economia brasileira vive um período próspero entre 2003 e 2010, no qual consegue combinar crescimento do produto com melhora distributiva. Segundo Serrano e Summa (2012) dois devem ter sido os fatores que contribuíram para isto: o cenário externo favorável e políticas internas distributivas e de estímulo à demanda agregada, entre elas, aumentos reais no salário mínimo, ampliação de programas de transferência de renda e o acesso facilitado ao crédito. A seguir cada um desses aspectos será discutido a luz de estudos empíricos na área e de interpretações pelo arcabouço teórico neo-Kaleckiano.

\subsubsection{Boom no preço das commodities e Investimento}

Figura 8 - Evolução do preço das commodities

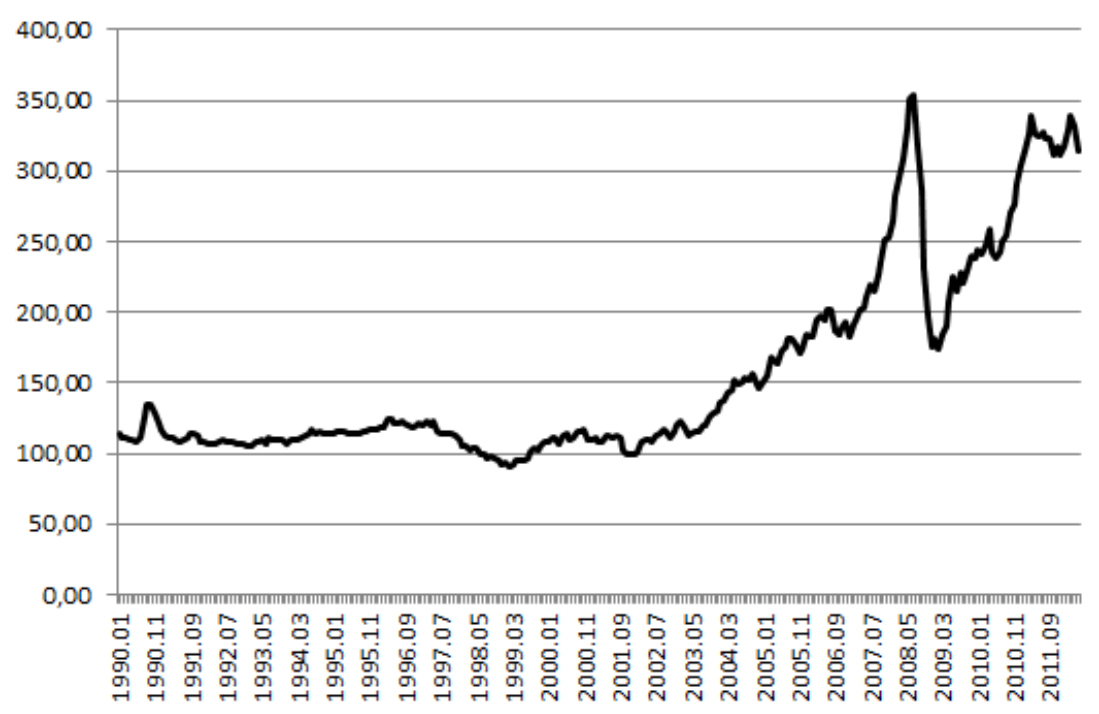

Fonte: IPEA-Data

O primeiro destes fatores está retratado na Figura 8. A alta demanda por produtos primários decorrente principalmente do crescimento acelerado da China se reflete sobre o preço das commodities. De 2003 até 2011 fica clara a ascensão deste índice que se mantinha em patamar constante até então. Isto estimula um fluxo maior de renda de exportações entrando no país, que recai sobre a demanda agregada interna. O efeito é verificado, por exemplo, em Santos et al. (2015), que em estudo econométrico encontra que a Formação Bruta de Capítal Físico $(\mathrm{FBCF})^{1}$ trimestral no Brasil responde positivamente ao preço internacional das commodities. Também encontra que a FBCF responde positivimente à FBCF da APU (Administração pública) e negativamente à taxa de câmbio.

1 Santos et al. (2015) atenta para a dinâmica distinta da FBCF em máquinas e equipamentos em relação à em construções; enquanto a primeira é mais reativa ao ambiente econômico, a segunda mostra-se mais estável, em decorrência da maior participação das famílias e do governo. O estudo econométrico de causalidade citado se restringe à primeira. 
O resultado positivo dos preços de commodities sobre a economia pode ser interpretado através do arcabouço neo-Kaleckiano. Carvalho e Rugitsky (2015) oferecem duas explicações, partindo da função de investimento Kaleckiana-Steindliana. A primeira ligada ao espírito animal dos investidores: altos preços estariam sinalizando crescimento da demanda mundial pelas exportações nacionais instigando os empresários a investirem mais. A segunda relacionada ao grau de utilização e à margem de lucros: dada a importância de produtos primários na estrutura produtiva brasileira, o preço das commodities estaria aumentando a margem de lucro e o grau de utilização das firmas, afetando assim o investimento não só neste setor, mas possivelmente em setores próximos na cadeia produtiva. Qualquer que seja o canal, parece nítida a influência positiva deste fator sobre a expansão econômica até 2010 e deve ter contribuído para a desaceleração da economia nos últimos anos. Um último canal de transmissão, que Carvalho e Rezai (2015) relaciona mais à taxa de câmbio, é o alívio da restrição externa. Altos preços de commodities aumentariam o fluxo de moeda estrangeira no país e aliviariam o pagamento da dívida externa existente no balanço de pagamentos e no fluxo de caixa individual das firmas.

Carvalho e Rugitsky (2015) oferecem explicações ainda sobre o efeito negativo proveniente da taxa de câmbio. Entre eles o já mencionado efeito balanço de pagamento em firmas que possuem dívida externa; o aumento do custo de se importar máquinas e equipamentos; a baixa elasticidade-preço de produtos primários exportados pelo país assim como a dependência de importações de produtos sem equivalentes nacionais; e a possibilidade das firmas apenas incorporarem o aumento da margem de lucro ao invés de investi-la. É curioso notar que tal efeito vai de encontro ao esperado pela literatura que trata do efeito de economia aberta sobre regimes de demanda. O possível aumento dos mark ups das firmas e o barateamento do produto no mercado externo decorrentes de desvalorizações cambias não estaria incentivando o investimento, como supõem os modelos que abordam o efeito de economia aberta. Os impactos negativos da desvalorização - via compressão do consumo e pressões inflacionárias - devem no caso brasileiro superar o potencial efeito positivo da maior competitividade. Olhando para os dados disponíveis, a formação bruta de capital fixo da economia brasileira de fato cresce em média 8,7\% ao ano no período 2004 a 2011 (SCN-IBGE 2000), em parte pelos mencionados efeitos da demanda externa por exportações, da taxa de câmbio valorizada no período e em resposta à $\mathrm{FBCF}$ da $\mathrm{APU}^{2}$.

\subsubsection{Políticas distributivas e consumo}

Apesar do impacto positivo da prosperidade no mercado internacional, deve-se também considerar aspectos da política econômica interna, em particular os que afetaram

2 Quanto ao efeito positivo da FBCF da APU sobre o investimento, Santos et al. (2015) argumenta parecer razoável que programas de investimento público do período, como o PAC, surtiram efeito positivo sobre o investimento privado. 
a distribuição da renda no país, como atentam Serrano e Summa (2012). Dentre eles, pode-se mencionar um tratamento mais ativo a ajustes no salário mínimo. A taxa de crescimento de seu valor real é crescente desde a estabilização de preços, mas a partir dos anos 2000 este aumento torna-se mais expressivo, como assinalam Carvalho e Rugitsky (2015). Em grande parte por políticas deliberadas de valorização real, através de correções nominais baseadas no crescimento do PIB dos últimos dois anos e na taxa de inflação anual - a partir de 2011 este mecanismo de correção vira lei. Combinado a isto ocorre o aumento da formalização no mercado de trabalho e a redução do desemprego. Considerando que o salário mínimo também serve como base para o pagamento de programas de seguridade social e para o pagamento de transferências a trabalhadores rurais, não deve surpreender o efeito positivo destes aumentos contínuos sobre a distribuição da renda.

Outro fator que certamente contribui para alterar a estrutura distributiva é a expansão de programas de transferência de renda, principalmente o Bolsa Família, cujo objetivo é garantir uma renda mínima a famílias pobres, condicionadas à comprovação da frequência escolar mínima das crianças da família e a visitas regulares a postos de saúde. Estudos que avaliam a distribuição dos benefícios concedidos estimam que 50\% dos gastos totais do programa destinam-se a famílias dentre as $15 \%$ mais pobres da distribuição, enquanto $90 \%$ de seu valor é destinada às $45 \%$ mais pobres (Hoffmann (2013)).

Figura 9 - Distribuição funcional vs. distribuição intrasalarial

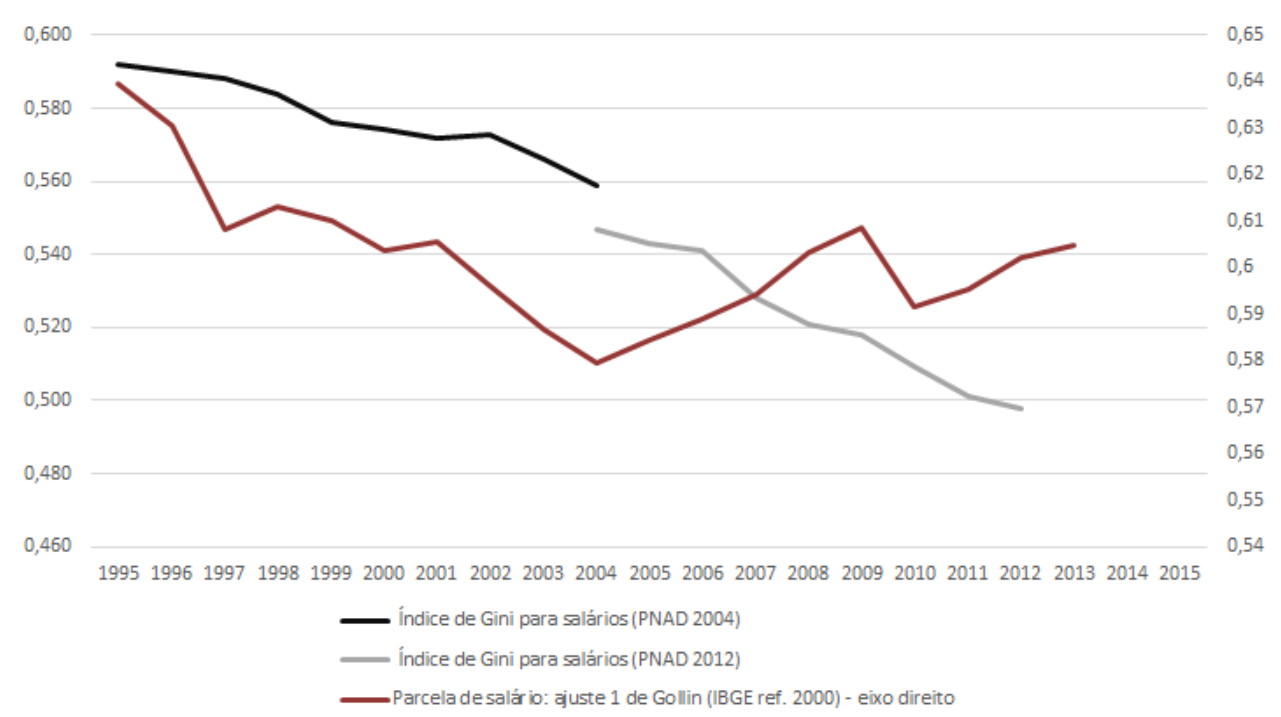

Fonte: IBGE e PNAD

É difícil medir o impacto distributivo dessas políticas. O índice de Gini, ao dar menos peso relativo à renda apropriada pelo parte mais rica da população, poderia estar subestimando a concentração da renda. Este problema fica evidenciado em Medeiros, Souza e Castro (2015), que além da possível subestimação, apontam para a possibilidade de erros de medida nas estimações da porcentagem da renda apropriada pelos mais ricos. 
Ao analisarem dados de impostos de renda concluem que a renda apropriada pelo percentil superior da distribuição deve ser em torno de $25 \%$ em vez de $18 \%$ estimado pelo censo demográfico. Estima ainda com dados de patrimônio e lucro que os $5 \%$ mais ricos na pirâmide distributiva, que detinham $40 \%$ da renda total em 2006, passam a deter $44 \%$ em 2012, e conclui que praticamente não houve queda na desigualdade de renda total nos últimos anos. Apontam o pagamento extremamente lucrativo de juros aos encargos da dívida como um dos possíveis motivos por trás disso.

Não obstante a conclusão em Medeiros, Souza e Castro (2015), parece clara a tendência de desconcentração da renda dos salários evidenciada pela PNAD ${ }^{3}$. Isto está representado na Figura 9 que mostra a trajetória da parcela salarial (distribuição funcional) e do índice de Gini para salários da PNAD (distribuição pessoal). Tais gráficos mostram reversão na tendência decrescente do primeiro indicador a partir de 2004 e redução persistente do segundo desde a estabilização de preços pós plano real. Programas sociais e os aumentos de salários mínimo, ao aumentar o salário médio dos trabalhadores da base da pirâmide, devem ter contribuído para ambas tendências.

Santos et al. (2015) ressalta a influência de tais mudanças distributivas sobre a trajetória do consumo das famílias, que segundo dados do SCN-IBGE (ref. 2000), cresce em média 5,1\% ao ano em termos reais no período 2004-2011. Atribui tais números em parte ao aumento da renda disponível das famílias, mas também ao efeito da formalização no mercado de trabalho no período em questão. Segundo dados do SCN-IBGE (2000), 12,6 milhões de novos empregos foram criados entre 2004 e 2009, 90\% com vínculos formais e 6 milhões entre 2010-2013 segundo dados da RAIS/CAGED. Em ambas pesquisas, o crescimento do emprego é maior no setor de serviços (sem administração pública).

Observe que a relação entre consumo e distribuição funcional e intrasalarial da renda pode ser analisada pelo arcabouço neo-Kaleckiano. Os modelos seminais preveem efeito positivo do aumento da parcela de salários sobre o consumo - uma vez que a propensão a consumir dos trabalhadores é maior do que a dos capitalistas. Extensões ao modelo que incorporam a influência da distribuição pessoal sobre a demanda (Carvalho e Rezai (2015); Palley (2014)) sugerem que a redução na dispersão dos salários deve alargar o consumo, uma vez que elevam a propensão média a consumir dos trabalhadores - os do topo na distribuição devem ter uma propensão a consumir bem menor do que os da base.

Rugitsky (2016) interpreta a relação entre o aumento da renda disponível e formalização no mercado de trabalho como um círculo virtuoso: aumentos no salário mínimo e nas transferências públicas de renda, especialmente às famílias mais pobres, criam demanda por bens manufaturados e por serviços, que por sua vez, levam à criação de postos

3 A Pesquisa Nacional por Amostra de Domicílios (PNAD) só coleta dados de rendimentos do trabalho; não questiona famílias sobre rendimentos mensais do capital, aplicações, imóveis e outros ativos, isto é, patrimônio e lucro. 
de empregos nestes setores, gerando mais renda. O setor de serviços em especial é tipicamente trabalho-intensivo e emprega usualmente mão de obra não qualificada; isto é, amplia o emprego e a renda majoritariamente na base da distribuição.

Figura 10 - Operações de crédito do sistema financeiro a pessoas físicas/PIB

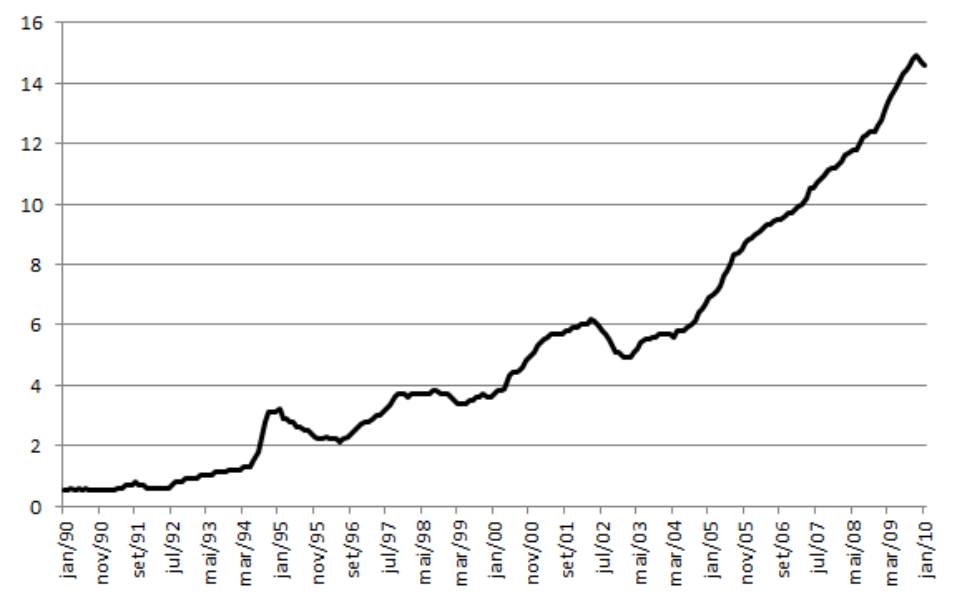

Fonte: $\mathrm{BCB}$

\subsubsection{Endividamento e o consumo}

Outro fator relevante para explicar a dinâmica do consumo no período foi a acessibilidade facilitada ao mercado de crédito. Entre os motivos por trás de tal fenômeno, Santos et al. (2015) elenca o crescimento real dos rendimentos do trabalho, reduções sucessivas na taxa de juros, o dinamismo no mercado imobiliário e a criação do mecanismo de crédito consignado. Este último é formalizado institucionalmente em 2004 e consiste num empréstimo deduzido mensalmente e automaticamente da folha salarial do devedor, portanto seguro às instituições financeiras. Tais fatores possibilitam a inclusão da população da base da pirâmide distributiva, antes excluída, ao mercado de crédito e contribuíram para alavancar o consumo. Isto fica ainda mais claro quando constata-se que a redução na taxa de crescimento do consumo das famílias em 2011 é concomitante à desaceleração do crédito das famílias de 2010 em diante. Como fica evidente na Figura 10, o crédito doméstico tem tendência ascendente de 2003 a 2009, que a partir de 2010 fica menos expressiva. Empiricamente, Schettini et al. (2012) encontra evidências econométricas de que o consumo agregado responde positivamente à razão crédito a pessoas físicas/PIB no Brasil.

A discussão sobre consumo e endividamento também pode ser interpretada pelo arcabouço Kaleckiano. Extensões desses modelos que consideram o efeito do endividamento sobre este componente da demanda (Dutt (2006), Setterfield e Kim (2016)) não chegam a conclusão unânime sobre seu efeito. No curto prazo deve ter de fato um efeito 
positivo sobre a demanda agregada, pois funciona como uma fonte alternativa aos salários de financiamento do consumo. Por outro lado, tem um efeito concentrador no médio e longo prazo: ao pagarem juros, trabalhadores transferem parte de sua renda a lucros de bancos e outras instituições financeiras, o que intensifica a desigualdade funcional da renda. A literatura Minskiana também atenta para a possível instabilidade financeira que a alta alavancagem do setor privado e das famílias pode surtir no médio e longo prazo. Portanto, como apontam Carvalho e Rugitsky (2015), apesar de configurar instrumento de política econômica adequado no curto prazo para incluir novas famílias no mercado de consumo, seu caráter concentrador no longo prazo pode ter efeitos contracionistas sobre a demanda agregada e desestabilizadores sobre o mercado financeiro.

O caráter dúbio desta alavanca também fica claro no modelo desenvolvido no capítulo anterior: enquanto que no curto prazo a maior predisposição ao endividamento sempre gera acréscimos de demanda, no longo este efeito não tende a se manter. Os encargos pagos sobre o estoque de dívida contraída deve acabar anulando o efeito de curto prazo.

Em suma, são vários os elementos por trás da expansão econômica com melhora distributiva experimentada pelo Brasil nos anos 2000. Dentre eles um mercado internacional aquecido, políticas que aumentaram a renda média de famílias na base na distribuição e a fácil acessibilidade ao crédito. A sustentabilidade do modelo é questionável pelos desafios que incorreu sobre a estrutura produtiva e sobre o grau de endividamento das famílias e empresas num médio e longo prazo.

\subsection{Dados}

Os dados utilizados neste exercício estão caracterizadas na Tabela 4 abaixo, de acordo com sua fonte e com a descrição do que representam. As séries para distribuição funcional da renda e distribuição pessoal - índice de Gini para salários - foram construídas neste trabalho e a descrição sobre a metodologia por trás será apresentada a seguir.

\subsubsection{Distribuição funcional anual}

A escolha da série anual para a distribuição funcional não é trivial. A série mais longa disponível é a anual de Marquetti e Porsse (2014) que engloba o período 1952-2008, mas sua metodologia de estimação não é muito clara. Pode-se também computar estimativa para esta variável pela conta de Renda da Tabela de Recursos e Usos (TRU) das Contas Nacionais, que apresenta a distribuição de renda entre os setores institucionais em três categorias: Remunerações dos Empregados, Excedente Operacional Bruto e Rendimento Misto Bruto (ou de autônomos). Contudo o cômputo da distribuição funcional com esta divisão deve levar em conta a origem e destino híbrido das rendas do trabalho e do 
Tabela 4 - Dados

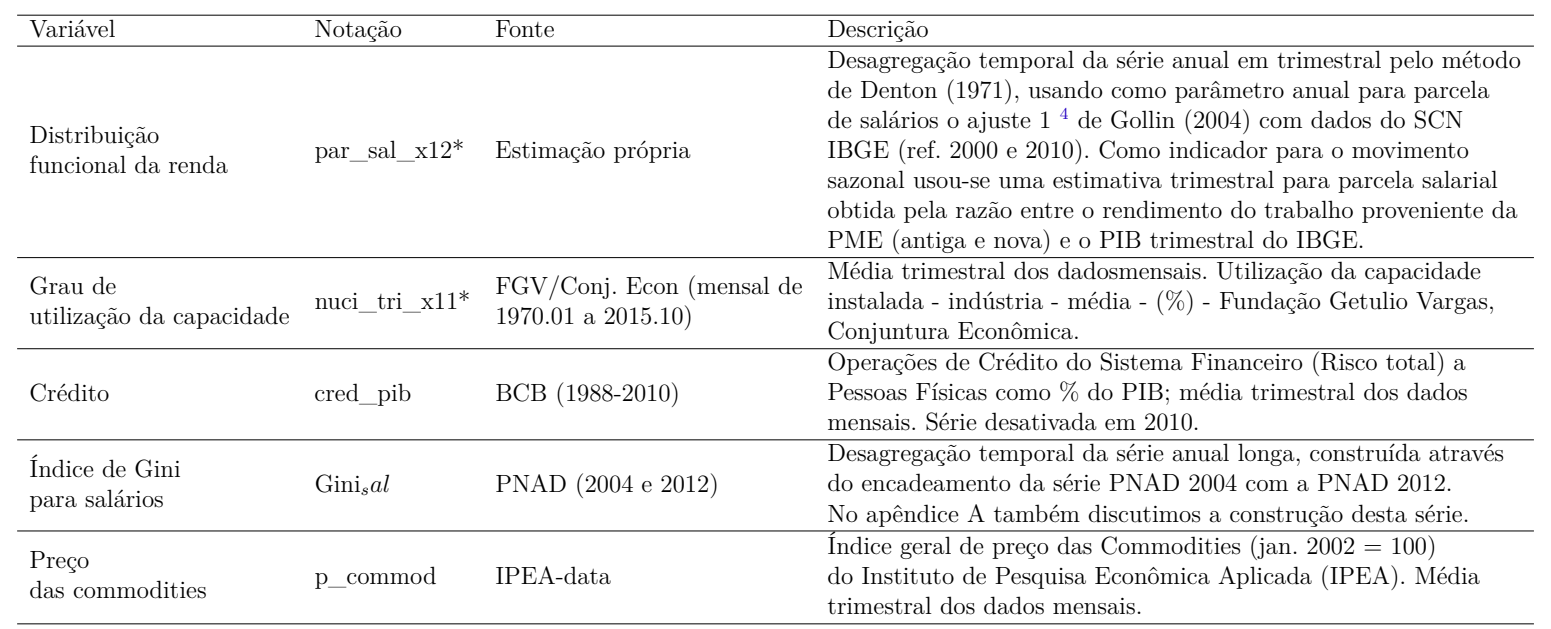

capital. Autônomos recebem renda do capital e do trabalho; empregados, que têm alguma poupança, auferem renda do capital; e detentores do capital também recebem renda de trabalho.

A metodologia para o cômputo dessas séries pelo IBGE muda em 2010. Existe uma série com valores anuais de 1990-2009 com referência metodológica de 2000 e outra que vai do período 2000-2013 com a nova metodologia, referência 2010. Na metodologia antiga, as contas nacionais apresentam os valores para os Rendimentos Autônomos e para o Excedente Operacional Bruto separados. Na nova metodologia o IBGE agrega esses dois componentes na TRU e o apresentam como um só denominado Excedente Operacional Bruto e Rendimento Misto Bruto.

O cômputo para a variável de distribuição funcional da renda envolve considerações e hipóteses sobre os três componentes discutidos acima. Segundo Considera e Pessoa (2011), ao levarem em conta os rendimentos de autônomos como renda exclusiva de propriedade (como as contas nacionais o fazem ao considerarem o rendimento misto como excedente), os países pobres têm comumente menores participações da renda do trabalho do que os países ricos.

Gollin (2002) propõe três metodologias para lidar com o problema da super ou subestimação no cômputo da distribuição funcional da renda. No Ajuste 1 trata todos os rendimentos de autônomos como remuneração do trabalho; no Ajuste 2 sugere dividir os rendimentos de autônomos como proporcionalmente dividido entre trabalho e capital; no Ajuste 3 sugere imputar aos autônomos um rendimento do trabalho semelhante ao rendimento médio de um empregado exercendo atividade semelhante, e a diferença em relação ao total dos rendimentos dos autônomos seria tratada como remuneração do capital. Todas as três alternativas elevam a participação do trabalho na renda em relação ao cálculo Ingênuo em que os rendimentos dos autônomos são atribuídos integralmente ao capital. 
Bastos (2012) e Considera e Pessoa (2011) realizam os três ajustes com as contas nacionais do IBGE referência 2000 com dados no período de 1995 a 2008. O primeiro conclui que o ajuste mais preciso para representar a parcela salarial é o Ajuste 1, que considera todo o Rendimento Misto Bruto como renda do trabalho. A Figura 11 retrata os cômputos próprios para a parcela salarial Ingênuo e pelo Ajuste $1 \mathrm{com}$ os dados do SCN-IBGE de referência antiga e nova.

Figura 11 - Parcela de Salário: Ingênuo vs. Ajuste 1

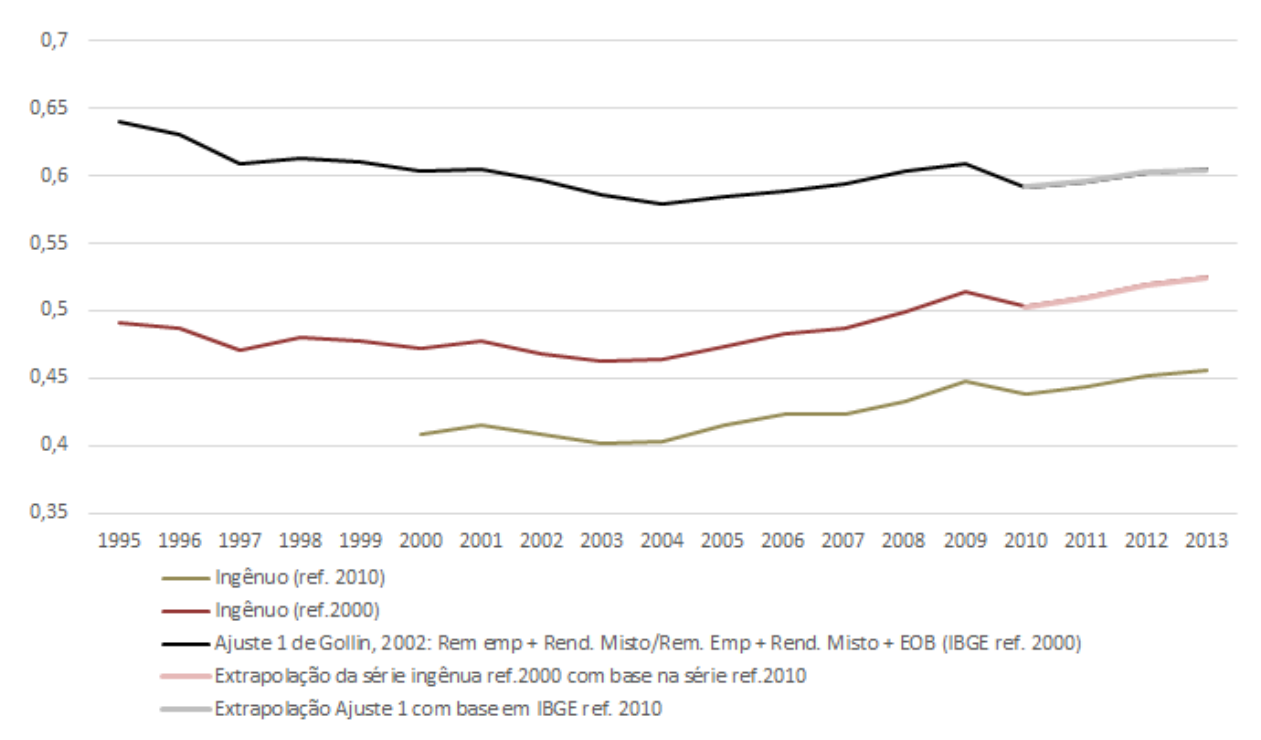

A fim de se obter uma única série com valores para a parcela salarial que vão de 1995 a 2013, as duas séries de metodologia distintas foram encadeadas. Partiu-se dos valores da série com referência em 2000 para o período 1995-2008, e realizou-se a seguinte conversão para o período 2009 a 2013:

$$
\psi_{2009-2013} \text { encadeado }=\psi_{2010} \times \operatorname{média}\left(\frac{\psi_{\text {ref.2000 }}}{\psi_{\text {ref.2010 }}}\right)
$$

Esta extrapolação é justificável, pois a razão entre as duas séries não parece ter tendência crescente nem declinante; oscila entre 1,14 e 1,15 nos anos em que as duas metodologias coexistem. A extrapolação para a série do Ajuste 1, entretanto, é mais delicada. Como não há divisão entre Rendimentos Autônomos e Excedente Operacional Bruto a partir de 2010, a extrapolação deve ser de tal forma que preserve as trajetórias de crescimento desses dois componentes. Tomando a Tabela de Recursos e Usos de 2010, a participação dos Rendimentos Mistos Brutos na soma Rendimento Misto Bruto + Excedente Operacional Bruto diminui de 29\% em 1995, para 19\% em 2009 ${ }^{5}$. Portanto,

5 Uma possível explicação para isso é a formalização no mercado de trabalho que ocorreu na última década. Parte dos autônomos passam a se formalizar, que se manifesta no alargamento da parcela de salários, notadamente no período 2004-2010. Por isso a tendência do cômputo ingênuo é mais crescente do que a do Ajuste 1, que leva em conta os Rendimentos Mistos. 
tomar a média deste percentual, aproximadamente $26 \%$, e aplicar ao valor agregado da metodologia nova para somar aos salários não parece razoável, uma vez que já se constatou a tendência declinante deste componente ao longo do período inteiro. Como solução, assumiu-se a hipótese de que os Rendimentos Mistos continuam decrescendo ao mesmo ritmo de 2010 a 2013 para a extrapolação.

\subsubsection{Distribuição funcional trimestral}

A partir da série anual do Ajuste 1, foi estimada uma série trimestral através do mecanismo de desagregação temporal, que utiliza um indicador trimestral para preservar o movimento sazonal da série. Este procedimento foi realizado, uma vez que a análise econométrica será feita com dados trimestrais por o maior número de observações oferecer maior robustez aos resultados.

Sax e Steiner (2013) discutem os métodos de desagregação disponíveis no software R. Entre eles, o método Denton (1971) e Denton-Chollete (Dagum e Cholette (2006)) se preocupam mais em preservar o movimento, gerando uma série de frequência alta similar ao seu indicador, mesmo que este não seja correlacionado com a série que será desagregada. Nestes dois métodos também é possível desagregar a série sem um indicador de frequência alta. Por outo lado, os métodos Chow e Lin (1971), Fernandez (1981) e Litterman (1983) usam geralmente mais de um indicador para realizar uma regressão na série de baixa frequência. Chow-Lin é preferível para séries estacionárias ou cointegradas, enquanto Fernandez e Litterman lidam melhor com séries não cointegradas. Todos estes métodos garantem que a soma, a média, a primeira ou a última observação da série de alta frequência seja consistente com a série de baixa frequência.

Bastos (2012) constrói uma série trimestral através do método de Denton (1971). Como o indicador para o movimento sazonal da série toma a parcela salarial trimestral estimada pela remuneração total aos empregados da Pesquisa Mensal do Emprego (PME) para regiões metropolitanas de Recife, Salvador, Belo Horizonte, São Paulo, Rio de Janeiro e Porto Alegre dividido pelo PIB brasileiro trimestral do Sistema de Contas Nacionais. Esta mesma estratégia foi adotada aqui a fim de reconstruir sua série e incorporar a ela observações mais recentes.

$$
\psi_{t r i}=\frac{\text { Rendimento médio nominal do trab. principal X População Ocupada }}{\text { PIB trimestral }}
$$

Estes dados estão disponíveis a partir de 1980, mas foram dispensadas observações anteriores a 1995 para iniciar a análise a partir de 1995, onde também se inicia a série anual. Há mudança na metodologia na PME em 2002, que requer encadeamento das séries. A série Rendimento Médio Nominal do Trabalho Principal Efetivamente Recebido no Mês de Referência (PME-IBGE, ref. 2002) foi usada para o período 2002-2015 e a 
série Rendimento Médio do Trabalho Principal (PME-IBGE antiga) para o período de 1995 a 2001. Os dados para "população ocupada" são obtidos na mesma PME que os rendimentos.

Para obter uma série trimestral longa para o período de 1995 a 2013, um encadeamento semelhante ao realizado na série anual foi feito para as séries trimestrais. Os valores a partir do segundo trimestre de 2002 foram obtidos pela parcela salarial estimada segundo a metodologia nova. As observações anteriores ao primeiro trimestre de 2002 foram obtidos da seguinte forma:

série encadeada $=$ parc. salarial met. antiga $X \frac{\text { par sal 2002t2 met. nova }}{\text { par sal 2002T2 met. antiga }}$

Figura 12 - Denton Aditivo: Desvios em nível (h0) vs. primeira diferença (h1)

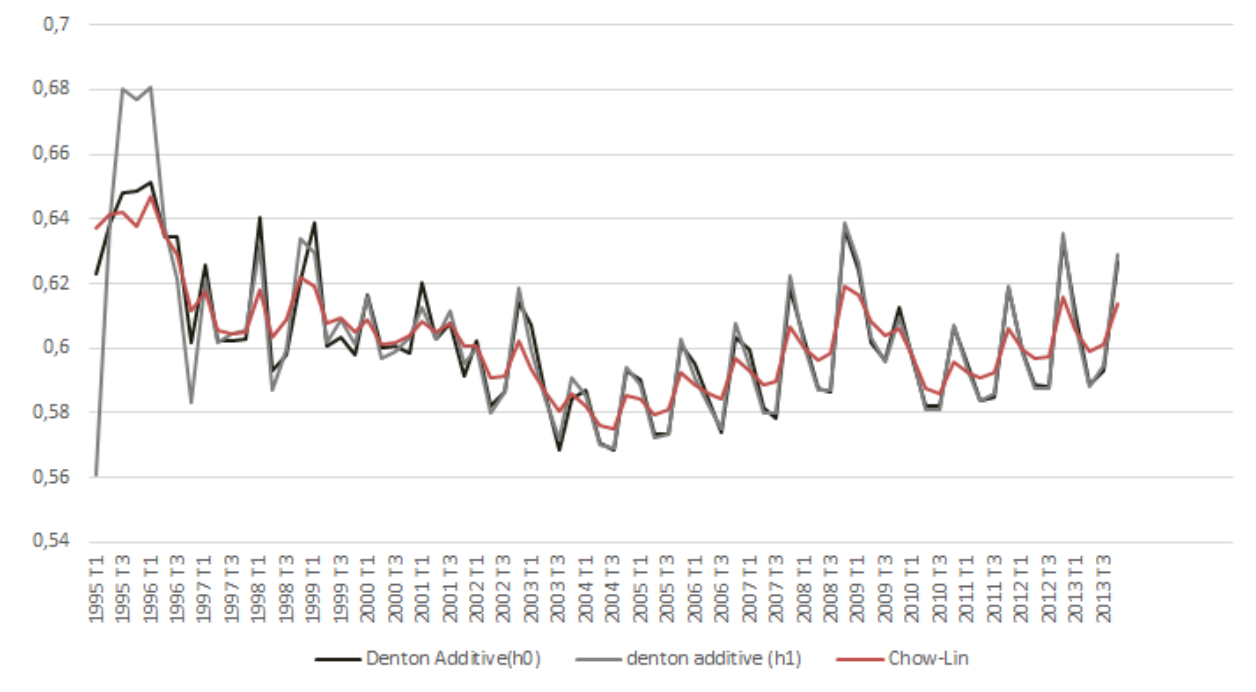

A partir dessas duas séries, o software $\mathrm{R}$ foi utilizado para desagregar a série anual, preservando o movimento sazonal trimestral da série obtida pela PME. Foram estimadas séries trimestrais pelos métodos de Denton, Denton Chollete e Chow-Lin, uma vez que tem-se apenas uma série indicadora que não aparenta ter raiz unitária.

As Figuras 12 e 13 comparam desagregações pelo método Denton (1971) com minimização dos desvios em nível e em primeira diferença nas formas aditiva ou proporcional. Nas duas figuras, também está plotada a desagregação pelo método Chow-Lin. Pela análise fica claro que adotar a minimização dos desvios em nível ou em primeira diferença não muda significativamente a trajetória da série. Optou-se por tomá-los em nível pois nas estimações que utilizam primeira diferença os picos parecem mais acentuados.

No método Denton, a preservação do movimento sazonal da série é maior que nos métodos alternativos que usam os indicadores como regressores, Chow-Lin neste caso, conforme mostra a figura. A escolha da série a ser usada nas estimações dos VARs não é 
Figura 13 - Denton Proporcional: Desvios em nível (h0) vs. primeira diferença (h1)

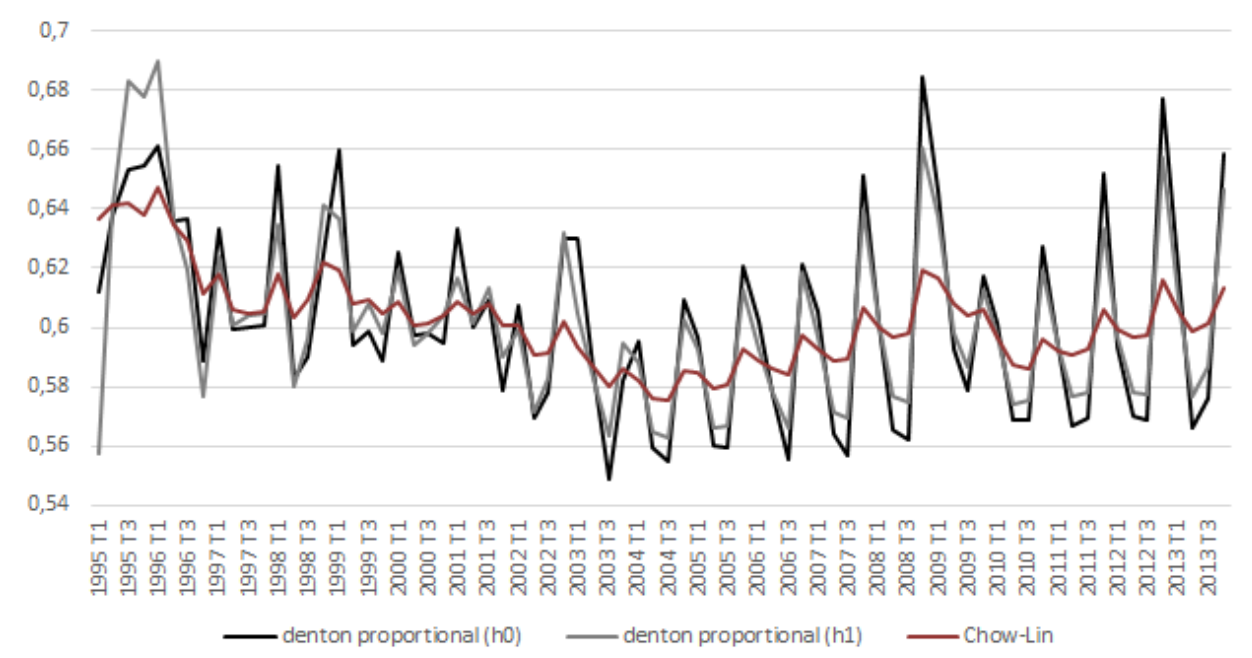

Figura 14 - Desagregação própria vs. Bastos(2012)

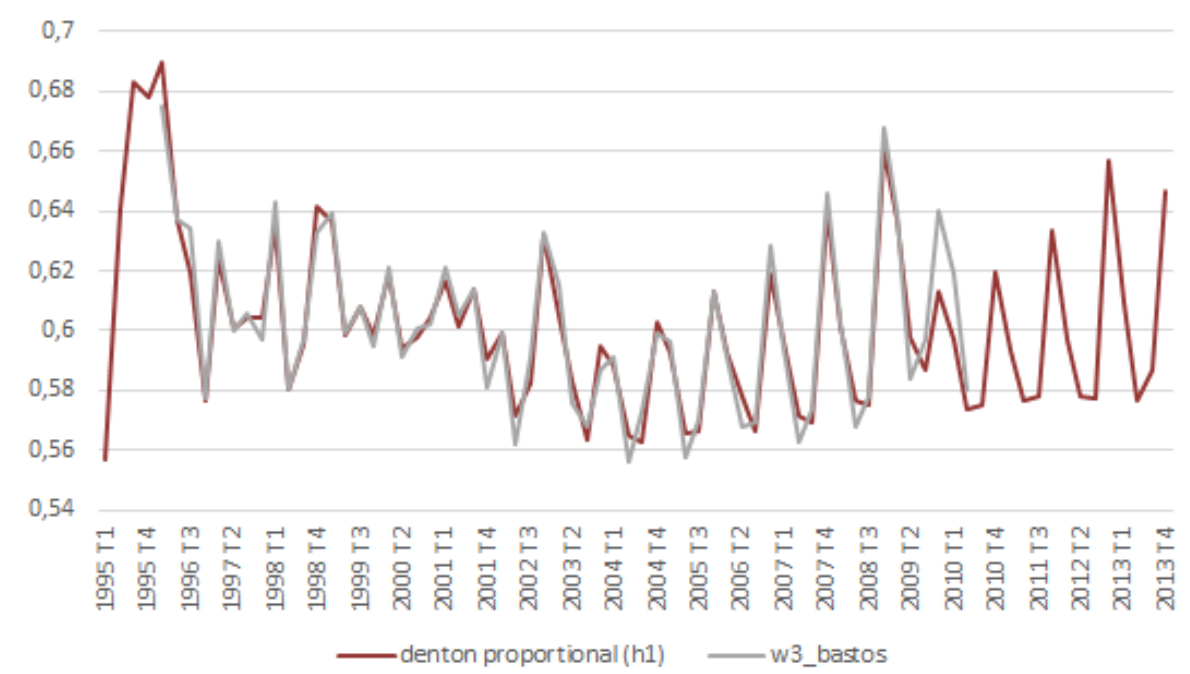

trivial, entretanto. Se por um lado o método Denton preserva o movimento sazonal, por outro, tamanha sazonalidade deve causar viés nas estimações, cuja solução seria a inserção de dummies temporais ou a dessazonalização de cada variável individualmente. Como já se havia começado a análise econométrica com a série de Bastos (2012) dessazonalizada, optou-se por manter esta escolha.

Outro exercício interessante é a comparação das séries aqui estimadas com a de Bastos (2012). A Figura 14 compara a série estimada por Bastos (2012) com a aqui estimada pelo método de Denton (1971) aditivo e com diferenças minimizadas em nível, mesmo método usado por ele. Observe que a desagregação aqui realizada se assemelha bastante à estimada por Bastos (2012), apesar da estimação própria apresentar mais picos. O descolamento das séries a partir de 2010 se deve às séries usadas por Bastos (2012) neste ano; como os dados das contas nacionais do IBGE ainda não estavam disponíveis, este faz 
uma previsão com base nos dados da PNAD do ano.

\subsubsection{Distribuição intrasalarial da renda}

Além da distribuição funcional da renda, busca-se aqui investigar a relevância de sua distribuição pessoal, em particular da distribuição intra-salarial. Não há um bom representante trimestral para este parâmetro, portanto, analogamente à série de distribuição funcional, um indicador trimestral foi construído. As duas séries anuais disponíveis que captam tal dispersão são versões para o índice de Gini para salários, provenientes da Pesquisa Nacional por Amostra de Domicílios - PNAD - do IBGE. Os parâmetros para o cômputo desta variável mudam em 2005. Até 2004 são levados em consideração todos os trabalhadores com mais de 10 anos de idade, enquanto que de 2005 em diante considerase apenas o rendimento mensal dos trabalhadores com 15 anos os mais. Portanto, têm-se disponível as seguintes séries:

1. Índice de Gini da distribuição do rendimento mensal das pessoas de 10 ou mais anos de idade (PNAD 2004) com rendimento: 1993 - 2004 (exceto os anos de 1994 e 2000)

2. Índice de Gini da distribuição do rendimento mensal do todos os trabalhadores das pessoas de 15 anos ou mais de idade, ocupadas na semana de referência (PNAD 2012): 2004 - 2012 (exceto 2010).

Figura 15 - Índice de Gini para salários: comparação

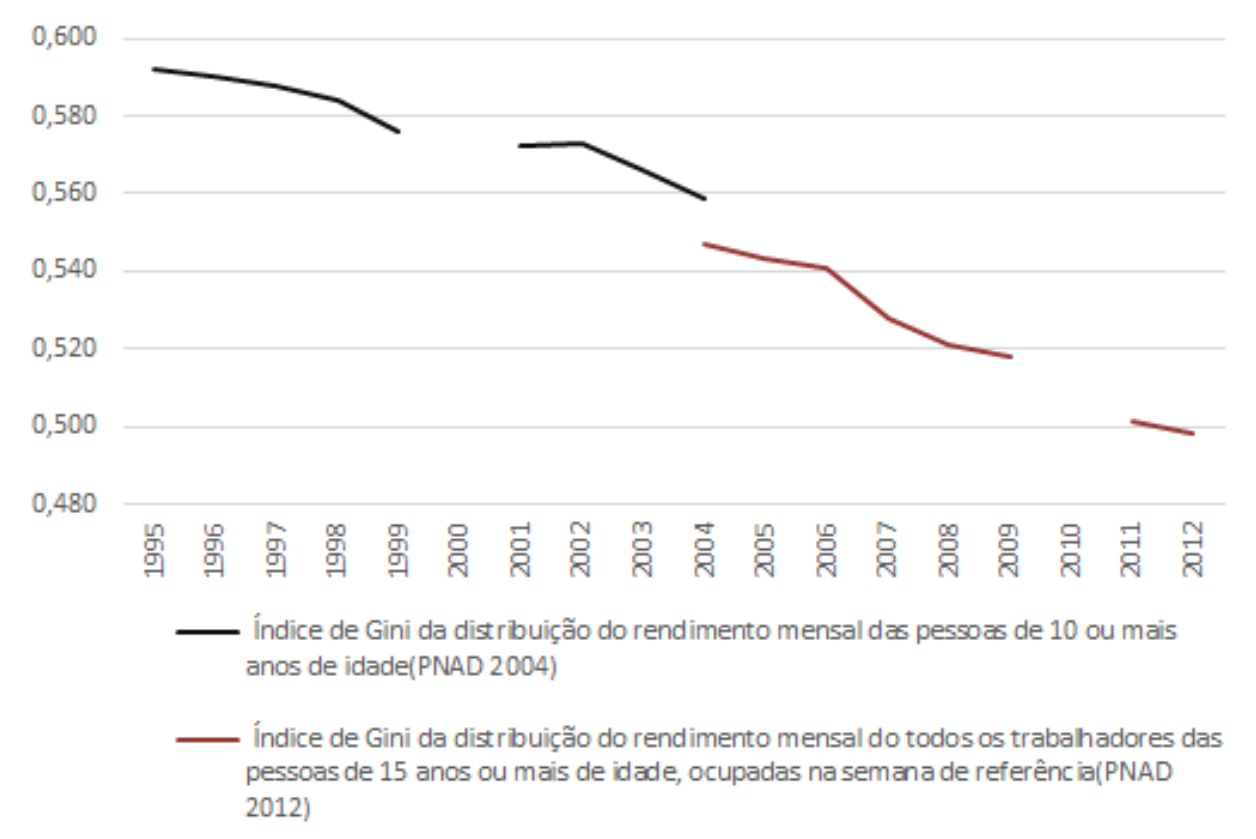

A Figura 15 retrata estas duas séries. Para que seja realizada a desagregação da série anual em trimestral, foi necessário primeiramente um encadeamento das duas séries, 
Figura 16 - Índice de Gini para salários: encadeamento das duas séries

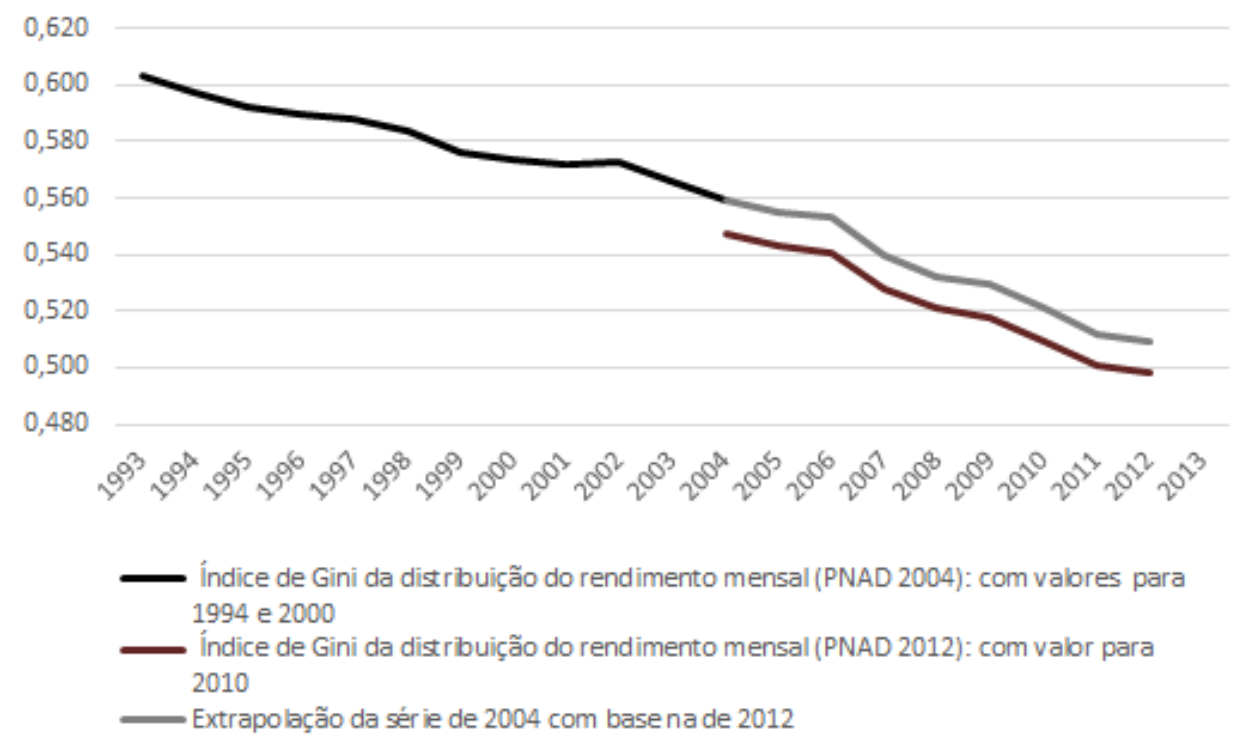

assim como uma estimação para os valores dos anos nos quais não há dados da pesquisa. Em relação a este último ponto, para os anos em que não há dados, os valores foram estimados segundo a média do ano anterior e do seguinte. Como fica evidente nas figuras, as duas séries parecem ter tendência semelhante de queda durante os anos. Assumiu-se que a diferença de nível entre as mesmas é decorrente da mudança na idade a que se referem cada uma delas. O ano de 2004 é o único que possui dados provenientes das duas metodologias, portanto foi usado como parâmetro. Então a partir de 2005 os valores da série foram definidos seguindo a seguinte fórmula:

série_encadeada $=$ Gini_sal_ref.2012X $\frac{\text { Gini_sal_ref.2004 }}{\text { Gini_sal__ref.2012 }} \mid($ ano_2004 $)$

O encadeamento está plotado na Figura 16.

A partir da série longa obtida para o período 1995-2012, realizou-se então a desagregação temporal para se obter a série trimestral. Como aqui não se tem parâmetro para o movimento sazonal da série, optou-se por usar o método de desagregação temporal disponível no software Eviews, denominado Cubic Match Last. O método consiste em inserir as observações de frequência baixa (anual) no último período da série de frequência alta (trimestral); para o quarto trimestre de 2009, por exemplo, será atribuído o valor anual de 2009. Em seguida realiza-se a interpolação do tipo cubic-spline dos valores ausentes para os três primeiros trimestres do ano. O resultado é a série exposta na Figura 17. 
Figura 17 - Índice de Gini para salários - série trimestral

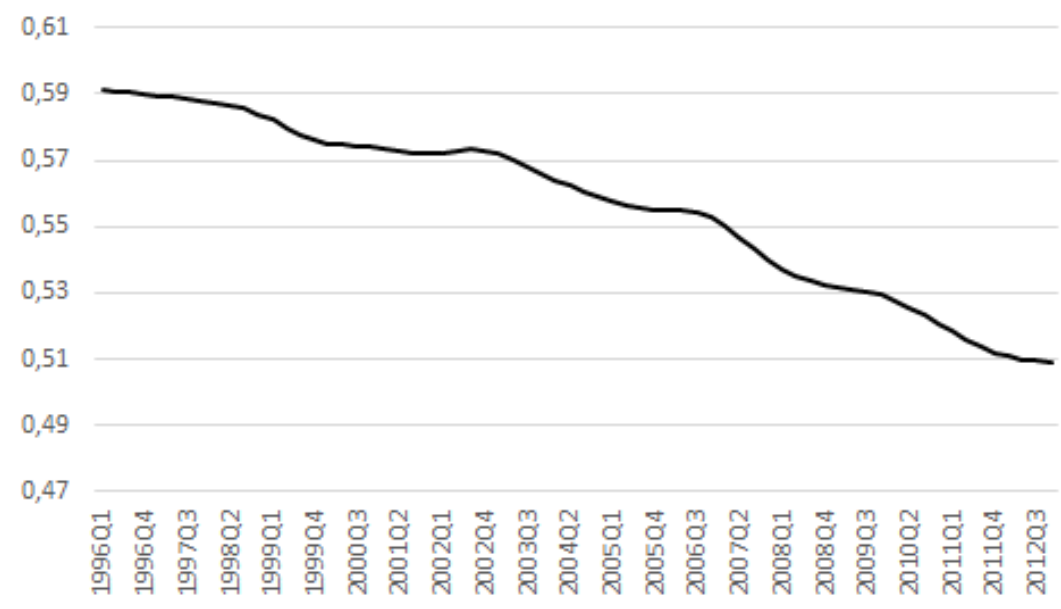

\subsection{Método VAR e a inclusão de variáveis exógenas}

O modelo VAR (vetor autoregressivo) Irrestrito foi proposto por Sims (1980), que criticava a metodologia de equações simultâneas no tratamento de séries temporais, pois estas exigiam classificação das variáveis em endógenas e exógenas, além de restrições que permitissem a identificação do modelo. É portanto um modelo puramente endógeno e alvo de algumas críticas justamente por tirar a importância da teoria econômica em sua formulação ao endogeneizar todas variáveis ${ }^{6}$. O VAR de ordem $\mathrm{p}-\mathrm{VAR}(\mathrm{p})$ - é definido por:

$$
y_{t}=\phi_{1} y_{t-1}+\phi_{2} y_{t-2}+\ldots+\phi_{p} y_{t-p}+\epsilon_{t}
$$

onde $y_{t}, \epsilon_{t}$ são vetores $N x 1, \phi_{i}$ uma matriz $N x N$. $\epsilon_{t}$ é um vetor de ruídos brancos $\left(E\left(\epsilon_{t}=\right.\right.$ $0)$, de modo que $E\left[\epsilon_{t} \epsilon_{t}^{\prime}\right]=\Omega$, e $E\left[\epsilon_{t} \epsilon_{s}^{\prime}\right]=0 \quad \forall t \neq s$, isto é, não existe correlação contemporânea entre as variáveis ${ }^{7}$.

A inclusão de variáveis exógenas que não dummies sazonais ou para outliers em vetores autoregressivos não é usual, mas pode ser realizada, como aponta Lutkepohl e Kratzig (2004). Sua inclusão pode comprometer a análise e inferência do modelo se as hipóteses de exogeneidade não forem satisfeitas.

Há três conceitos de exogeneidade de acordo com Engle, Hendry e Richard (1983). Um conjunto de variáveis $z_{t}$ é dito fracamente exógeno para um vetor de parâmetros

6 Posteriormente, Sims propõem o chamado SVAR (Structural VAR), ou VAR Estrutural, que impõe restrições de identificação, que devem seguir uma teoria econômica. Esta versão para o modelo é consagrada no artigo de Blanchard e Quah (1988).

7 A transição do processo gerador de dados das variáveis de estado para o modelo VAR estimado envolve quatro hipóteses metodológicas: (1) pode-se trabalhar com a função de densidade marginal das variáveis; (2) tal função pode ser aproximada por um função linear; (3) seus parâmetros são invariantes no tempo; (4) os ruídos do modelo têm distribuição normal (Barbosa-Filho e Taylor (2006)). 
de interesse, por exemplo $y_{t}$, se a estimação de $y_{t}$ condicional a $z_{t}$ não acarreta perda de informação relativa à estimação não condicional às variáveis ditas exógenas. $z_{t}$ é dito fortemente exógeno se é fracamente exógeno não só para os parâmetros do modelo condicional, mas também para as previsões, isto é, previsões de $y_{t}$ condicionais à $z_{t}$ não melhoram a previsão em relação ao modelo não condicional às variáveis exógenas. Finalmente, a superexogeneidade acontece se uma variável é fracamente exógena a outra e se ações de política que afetam o processo marginal do modelo condicional e de previsões de $y_{t}$ não afetam os parâmetros do processo condicional. Portanto, pode-se dizer que exogeneidade fraca é importante para a inferência, forte é importante para previsão e superexogeneidade para política econômica. A não rejeição da hipótese nula de uma variável $X$ não ser Granger-Causada $(G-C)$ por outra variável $Y$ combinada à não rejeição de existência de exogeneidade fraca acarretam a aceitação da exogeneidade forte.

\subsection{Exercício Econométrico e Resultados}

Figura 18 - Séries utilizadas nas estimações
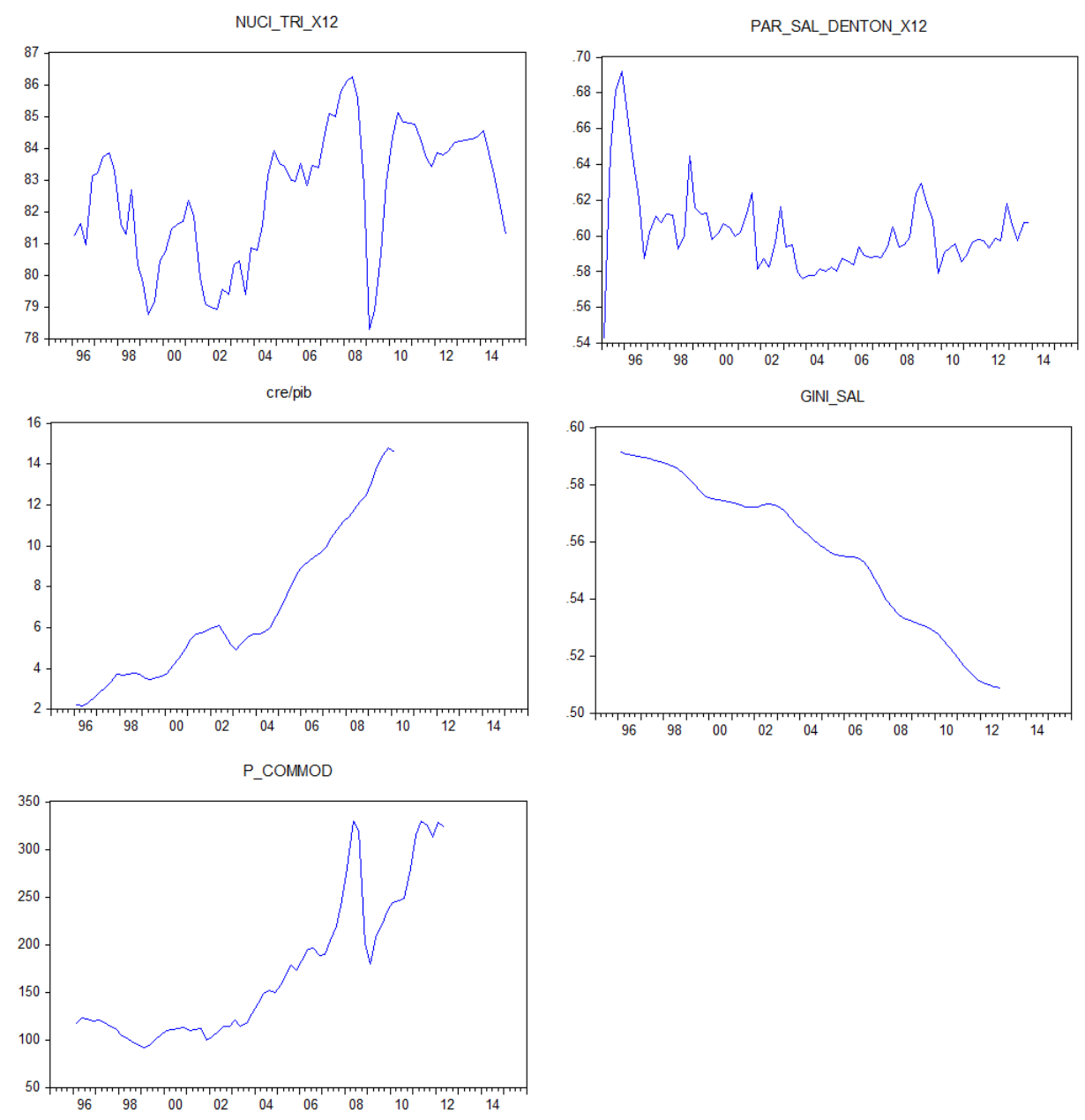

Para realizar este exercício, seguiu-se a estratégia empírica de estudos que buscam 
identificar a natureza de regimes de demanda de países pelo método VAR (Barbosa-Filho e Taylor (2006); Naastepad e Storm (2006)). Estes estudos utilizam estimações no plano $\dot{u}=\dot{\psi}=0 \quad$ para analisar ciclos econômicos pela literatura inspirada em Goodwin (1967). Os resultados geralmente sugerem resposta pró-cíclica dos salários (profit squeeze) e profitled do grau de utilização. A Figura 19 plota as flutuações da distribuição funcional e do grau de utilização da capacidade para o Brasil de 1996 a 2013.

Figura 19 - Flutuações na distribuição funcional e no grau de utilização

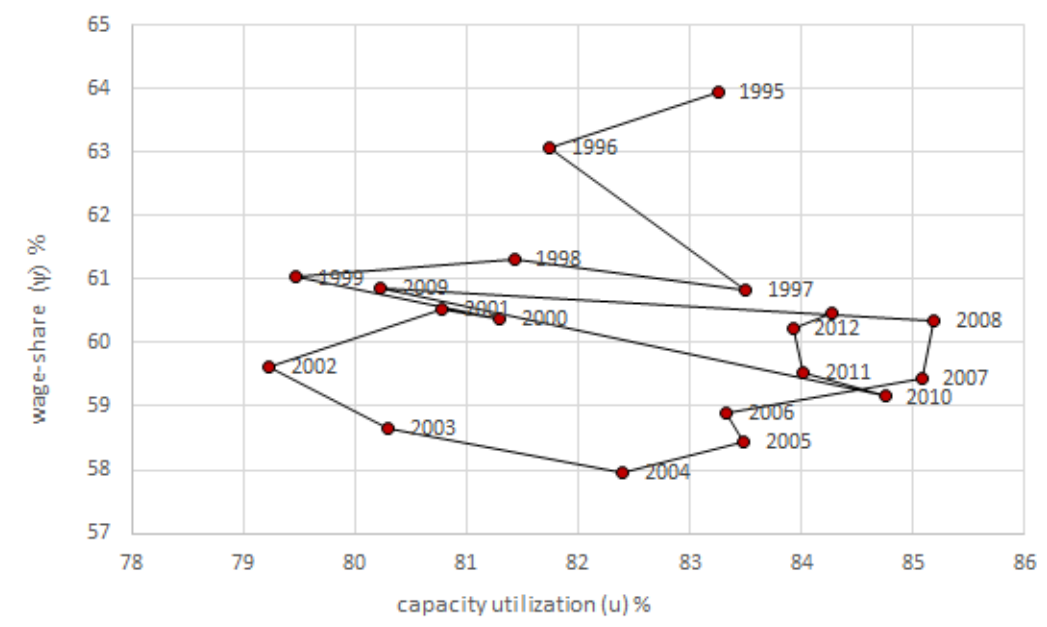

Entre 1995 e 2008, observa-se um movimento circular anti-horário, que parece estar ligado ao padrão cíclico no plano $(u, \psi)$ descrito na versão estruturalista do modelo de Goodwin (1967) em Taylor (2009). A parcela salarial, que atinge valor máximo no período de análise em 1995, começa a cair a partir daí, delineando junto ao grau de utilização da capacidade dois "meio-ciclos", 1995-1997 e 1997-2000, e um ciclo quase completo de 2000 a $2009^{8}$. De 2010 a 2013, esta tendência, entretanto, parece ser revertida; o grau de utilização começa a reduzir enquanto os salários permanecem em ascensão. A abordagem cíclica inspirada em Goodwin (1967) parece razoável para explicar a relação entre grau de utilização e distribuição funcional da economia brasileira no período.

O propósito deste exercício, entretanto, não é de discutir a dinâmica cíclica entre as duas variáveis: o método destes estudos é usado aqui para chamar atenção ao problema de variáveis omitidas nas investigações empíricas que estimam regimes de demanda. Para tal, variáveis exógenas de controle que parecem relevantes para explicar a economia brasileira nos últimos anos e que são extensões teóricas ao modelo neo-Kaleckiano canônico foram incluídas nas estimações. São elas:

1. Índice de Gini para salários como representante para a distribuição pessoal da renda;

8 Apesar da drástica redução do grau de utilização neste último ano, que "fecha o ciclo" ser decorrente da crise. De qualquer forma a trajetória circular no período 2000 a 2008 é bastante evidente. 
2. Razão concessão de crédito a pessoas físicas PIB para a extensão de endividamento das famílias;

3. Índice de preço das commodities representando o efeito de economia aberta.

Essas três variáveis foram escolhidas com base na discussão sobre o desempenho da economia brasileira nos anos 2000 apresentada na seção 2.

Estimou-se VARs para grau de utilização $(u)$ e parcela de salários $(\psi)$, supondo $y_{t}=\left(\begin{array}{ll}u_{t} & \psi_{t}\end{array}\right)$, na equação (3.1), incluindo cada variável exógena $z_{i}$ de controle separadamente e um VAR com os três controles, e incluindo as dummies para outliers necessárias. Também foi estimado um VAR com as três variáveis de controle juntas. As equações (3.2) e (3.3) apresentam as duas equações estimadas.

$$
\begin{aligned}
& u_{t}=c_{u}+\gamma_{11} u_{t-1}+\gamma_{12} \psi_{t-1}+b_{i} z_{i}+c_{11} d 2009 q 1+c_{12} d 1998 q 4+c_{13} d 2001 q 4+\epsilon_{t 1} \\
& \psi_{t}=c_{\psi}+\gamma_{21} u_{t-1}+\gamma_{22} \psi_{t-1}+b_{i} z_{i}+c_{21} d 2009 q 1+c_{22} d 1998 q 4+c_{23} d 2001 q 4+\epsilon_{t 2}
\end{aligned}
$$

A amostra consistiu em algo entre 70 e 75 observações. As endógenas foram dessazonalizadas pelo método $x 12$ para corrigir a autocorrelação das especificações, que persistia sem isto. Pelos testes de raiz unitária concluiu-se que estas são $I(0)$, enquanto as três exógenas são integradas de primeira ordem, $I(1)$. No apêndice B a tabela com a significância dos coeficientes destes testes é apresentada.

Inseriram-se as variáveis exógenas diferenciadas nas especificações, uma vez que não faz sentido econométrico uma equação com variável dependente estacionária e explicativa não estacionária. Para padronizar as estimações, dummies para o primeiro trimestre de 2009 (crise financeira), para o quarto de trimestre 2001 (apagão no Brasil) e para o quarto de 1998, que mostraram-se necessárias para garantir normalidade dos erros. Testes de Hannan-Quinn e Schwarz sugeriram uma defasagem nas especificações.

Testes de Granger-Causalidade foram realizados para garantir exogeneidade das variáveis ditas "exógenas" e também encontram-se no apêndice. Seus resultados foram de não rejeição das hipóteses nulas de preço das commodities, índice de Gini para salários e endividamento das famílias não serem Granger-Causadas pelo grau de utilização (NUCI-FGV) e pela parcela salarial. As variáveis endógenas são estacionárias, portanto, a ausência de relação contemporânea entre elas e suas variáveis explicativas é hipótese do modelo. A não Granger-Causalidade e a hipótese teórica de exogeneidade fraca relacionada à ausência de relação contemporânea, garantem exogeneidade forte dos controles às dependentes. 
Tabela 5 - Coeficientes dos VARs

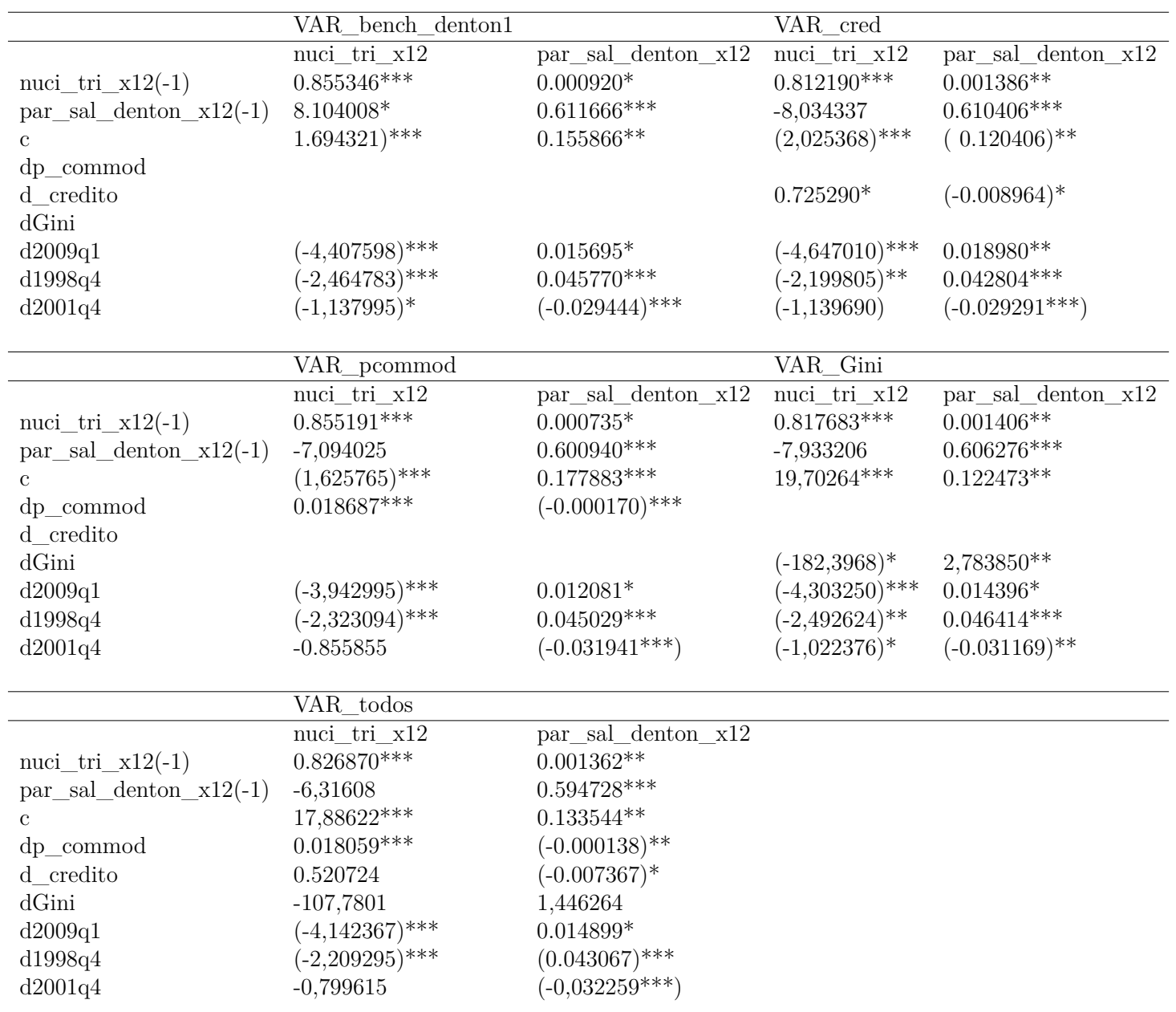

Os resultados sugerem curvas de demanda do tipo profit-led, uma vez que o coeficiente de parcela salarial é negativo em todas as especificações, apesar de só significante no VAR benchmark a 10\%. As curvas distributivas, por sua vez, assumem formato do tipo profit squeeze, pois o coeficiente do grau de utilização é positivo (significante em algumas das especificações) para a parcela salarial. Estas tendências ficam explícitas nas funções de resposta impulso analisadas mais adiante e se assemelham aos resultados de Barbosa-Filho e Taylor (2006) para a economia americana.

A Tabela 5 apresenta as especificações com os coeficientes e suas respectivas significâncias. Observe que os coeficientes das exógenas em todas estimações mostraram-se significantes para as duas variáveis endógenas a pelo menos $10 \%$. Na equação de demanda (para a nuci_tri_x12), a exógena mais significantes foi preço de commodities - significante a 5\%-, sinalizando efeito forte de economia aberta. Na equação da curva distributiva, o controle mais significante foi índice de Gini para salários a 5\%.

Estes resultados foram interpretados de duas maneiras: pela análise do sinal e significância dos coeficientes das exógenas na estimação de cada endógena, que representam alteração no intercepto das curvas distributiva e de demanda efetiva; e pela análise dos 
intervalos de confiança nas funções resposta ao impulso, que representam mudanças nas inclinações das curvas.

Nos VARs de crédito e de preço de commodities, o coeficiente destas variáveis exógenas na equação para o grau de utilização (nuci) foi positivo - desloca curva de demanda efetiva "para a direita" - enquanto o coeficiente para Gini salarial foi negativo - a desloca "para a esquerda". O efeito endividamento positivo sobre a demanda é esperado, uma vez que este potencializa o consumo no curto prazo. Preço das commodities ascendente pode ser encarado como um choque externo positivo sobre o componente autônomo do investimento ou como um valor maior para as exportações, ambas situações que deslocam a curva de demanda efetiva para fora. No caso do índice de Gini, quanto maior a concentração de renda intra-salarial, menor o efeito dos salários sobre a demanda agregada, pela menor propensão a poupar dos assalariados no topo da pirâmide distributiva em comparação aos da base, deslocando a ED para a esquerda. Portanto, da análise sobre o sinal e a significância dos coeficientes de cada uma das variáveis de controle, pode-se concluir que redução da disparidade de salários, aumento no endividamento das famílias e alta demanda por exportações (refletida no seu preço) devem ter impulsionado a demanda efetiva no Brasil no período de análise.

Figura 20 - Função Impulso Resposta da NUCI a choques na parcela de salários
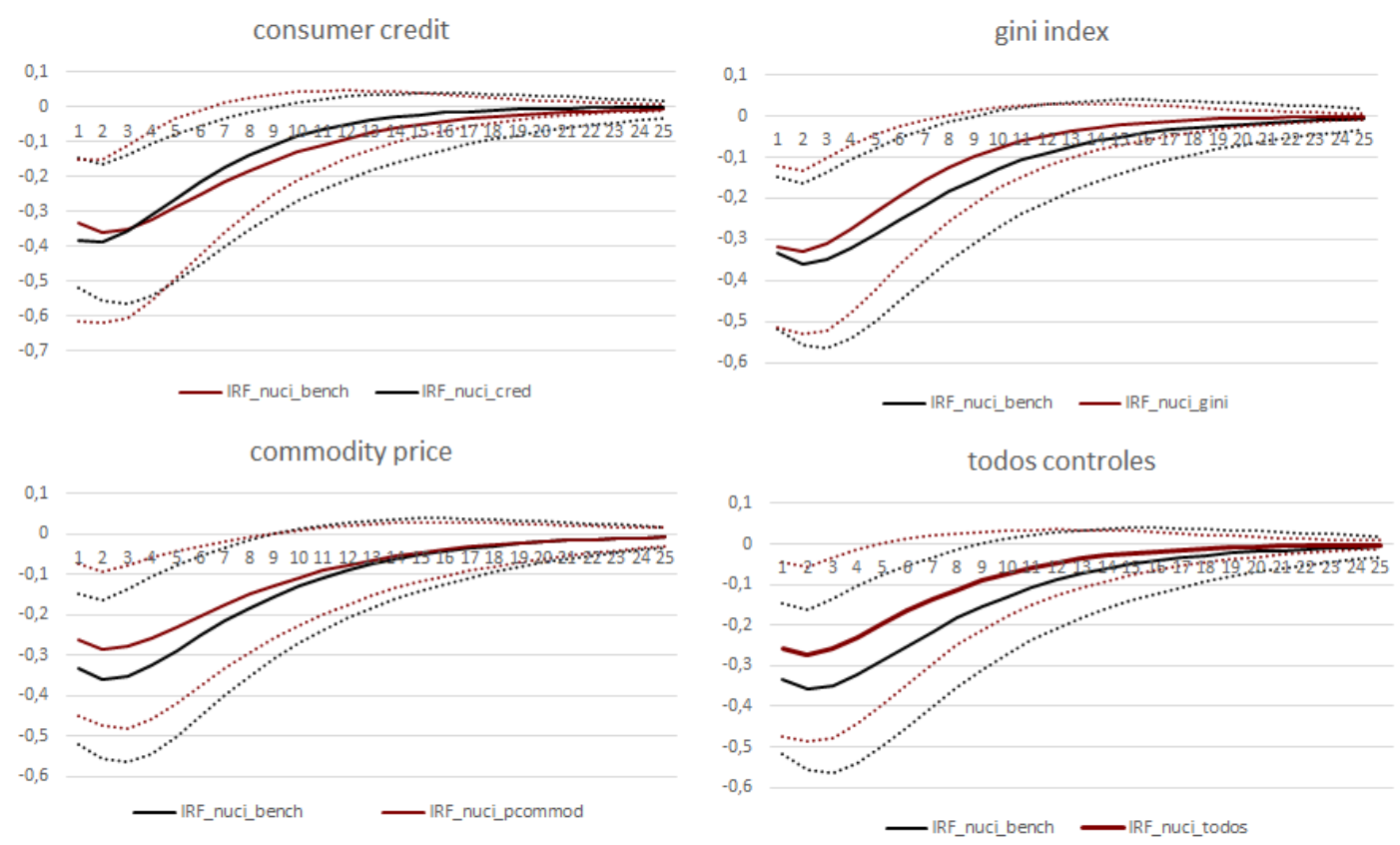

No caso da curva distributiva ${ }^{9}$, o coeficiente do índice de Gini para salários foi positivo em contraste aos coeficientes de crédito e de preço de commodities, ambos nega-

9 A interpretação dos resultados da curva distributiva segundo os modelos Kaleckianos é delicada, já que a discussão sobre o efeito das extensões no modelo é geralmente limitada à curva demanda efetiva. A análise sobre o sinal dos coeficientes de cada variável exógena realizado neste exercício é pautada no modelo do capítulo anterior e na discussão empírica sobre economia brasileira. 
tivos. O coeficiente de índice de Gini para salários positivo indica um deslocamento para a direita da curva distributiva e foi significante a 5\%. A concentração de salários a favor dos trabalhadores mais ricos estaria aumentando a parcela de salários na renda. Observe que este resultado se opõem resultado do modelo teórico desenvolvido no capítulo anterior. Naquela estrutura, o prêmio salarial era positivamente relacionado à parcela de lucros na renda e, portanto, negativamente à parcela de salários, se contrapondo ao resultado econométrico. Uma possível explicação é que os salários dos trabalhadores da base da distribuição são definidos por contratos e não podem ser reduzidos abaixo do salário mínimo. Portanto, acréscimos na remuneração dos trabalhadores ricos que de fato pioram o índice medidor de distribuição alargam a parcela total de salários na renda.

Figura 21 - Função Impulso Resposta acumulada da NUCI a choques na parcela salarial

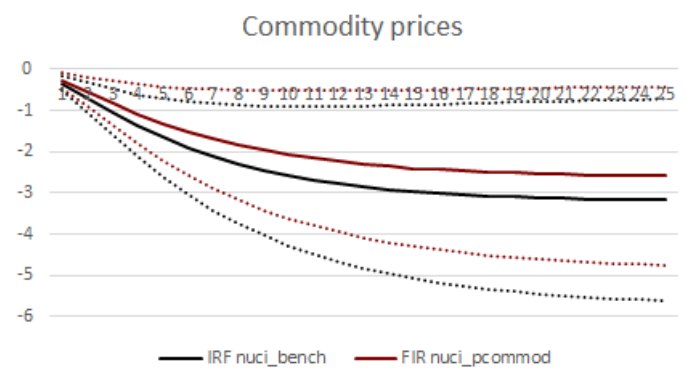

Gini index

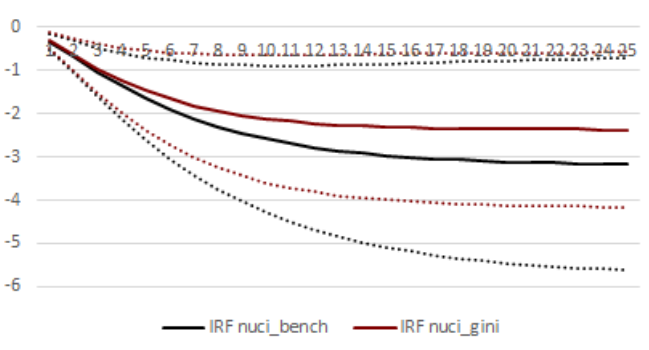

Consumer credit

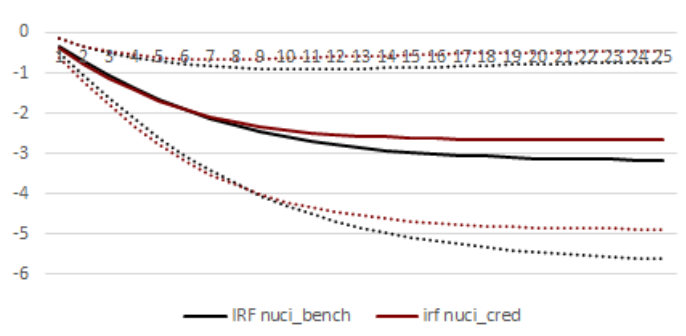

Todos controles

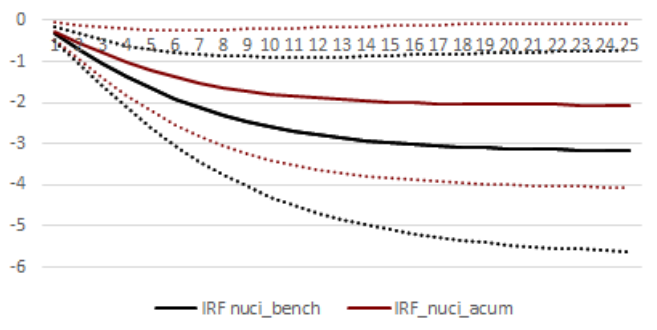

Os outros dois controles deslocaram a curva distributiva para dentro. As operações de crédito retratadas pelo VAR_cred têm efeito contracionista, apesar de extremamente pequeno e significante a $10 \%$, sobre a parcela salarial. Este resultado pode ser relacionado ao pagamento de juros que pode transferir parte da renda dos salários dos pobres aos ricos discutido no modelo do capítulo anterior e em outros neo-Kaleckianos que discutem dívida, como Dutt (2006), ainda que este não faça considerações diretas sobre curva distributiva. O resultado também negativo do coeficiente para preço de commodities pode ser atribuído ao fato dos setores exportadores não repassarem seus lucros a salários via reajustes e assim aumentar o peso relativo dos lucros em relação aos salários.

As funções resposta ao impulso, por sua vez, retratam como a influência de uma variável endógena na outra muda após a inclusão dos controles. Em todas especificações, a ordenação de Cholesky seguiu o modelo econômico com a parcela salarial antes do grau de utilização, isto é, se assumiu a hipótese de que a distribuição é mais exógena que a 
demanda. Pela análise da tabela de coeficientes, observa-se que as duas defasagens de ambas endógenas são significantes em sua estimação própria a 1\%. Em se tratando de defasagens cruzadas, o grau de utilização no período anterior é significante a pelo menos $10 \%$ na equação para a parcela salarial em todos VARs. Fica significante a $5 \%$ nos VARs de crédito e índice de Gini. Já a parcela salarial só é significante na determinação do grau de utilização no VAR benchmark a 10\%; a inclusão das variáveis de controle faz sumir essa significância em todas as outras especificações. Isto sugere que o grau de utilização é mais sensível às variáveis exógenas do que à parcela salarial e que, ao incluí-las, o efeito talvez erroneamente atribuído à distribuição funcional se perde nas estimações.

Figura 22 - Função Impulso Resposta da Parcela de Salários a Choques na NUCI
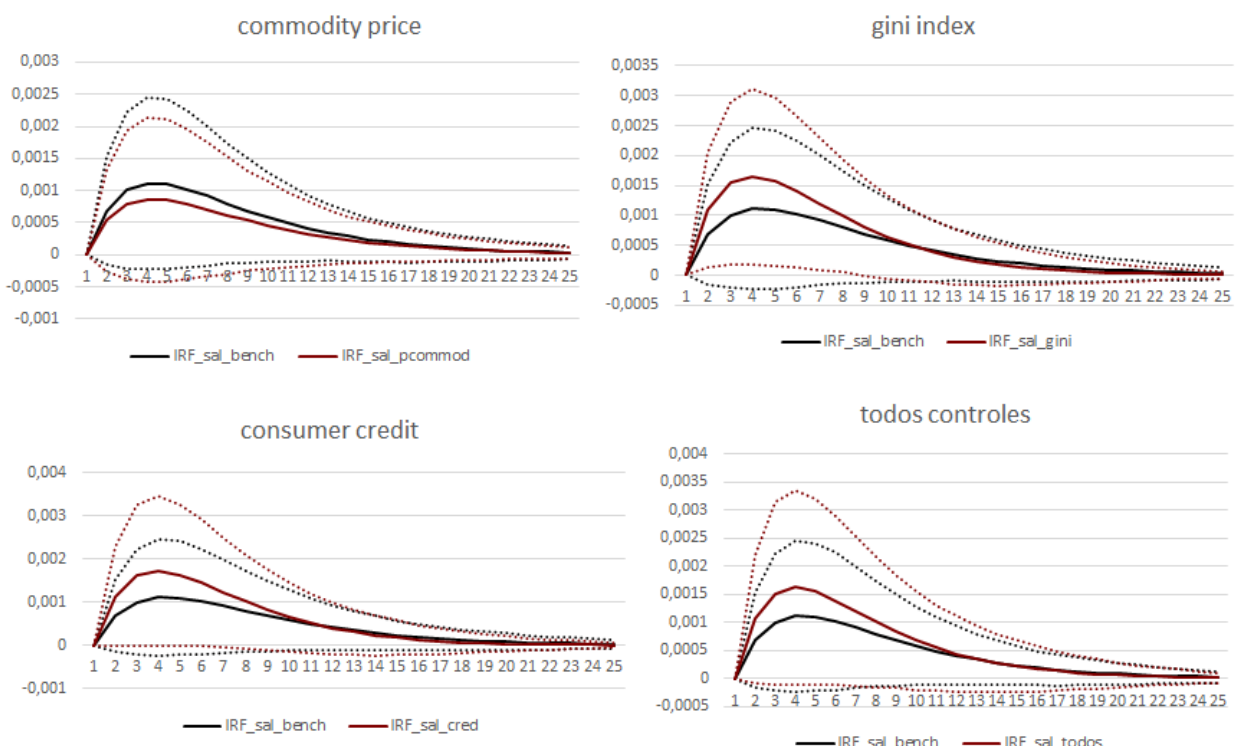

A tendência profit-led fica clara na curva de demanda efetiva, estatisticamente diferente de zero por aproximadamente 5 períodos e dissipada em aproximadamente 18 períodos em todas as especificações, conforme Figura 20. A resposta mais semelhante ao baseline, na qual o tracejado e o intervalo de confiança são muito parecidos à referência sem controle, é o do VAR que controla para crédito. Isto sugere que o endividamento das famílias não altera a inclinação da curva de demanda, mas apenas seu intercepto, conforme discutido acima. Nos demais, a economia fica menos profit-led, já que o controle para o efeito das exógenas reduz o limite inferior da função resposta ao impulso, especialmente no VAR que controla para preço de commodities, conforme fica evidente também na Figura 21. Pode-se dizer que tirando o efeito da competitividade externa via preços, o grau de utilização responderá menos negativamente a choques na parcela salarial, resultado esperado pela literatura de economia aberta nos modelos neo-Kaleckianos. Quanto ao VAR_Gini, o controle para a distribuição pessoal também estaria deixando a economia menos profit-led, uma vez que a concentração de salários no topo da distribuição enfraquece o estímulo à demanda proveniente do aumento da parcela de salários sobre o 
consumo. Finalmente, o VAR que controla para os três fatores também tem seu regime de demanda tornando-se menos profit-led. Apesar da tendência verificada nas funções resposta ao impulso, a classificação do regime de demanda da economia brasileira como profit-led não parece adequada pela dissipação da significância do coeficiente da parcela de salários na equação para o grau de utilização com a inclusão dos controles.

A tendência profit squeeze da curva distributiva foi comum a todas especificações e pode ser observada nas Figuras 22 e 23. Foi menos robusta nos VARs baseline e no que controla para o preço de commodities, pelo limite inferior negativo do intervalo de confiança. De novo, a interpretação sobre o efeito da inclusão dos controles sobre a curva distributiva é baseada no modelo do capítulo anterior e na análise sobre economia brasileira. O controle para preços das commodities enfraqueceu a tendência profit squeeze, sinalizando a relevância do choque externo positivo na renda do país. O controle para este fator estaria acirrando o conflito distributivo, ao enfraquecer a reação da parcela salarial diante de um choque de demanda.

Figura 23 - Função Impulso Resposta acumulada da parcela salarial a choques na nuci
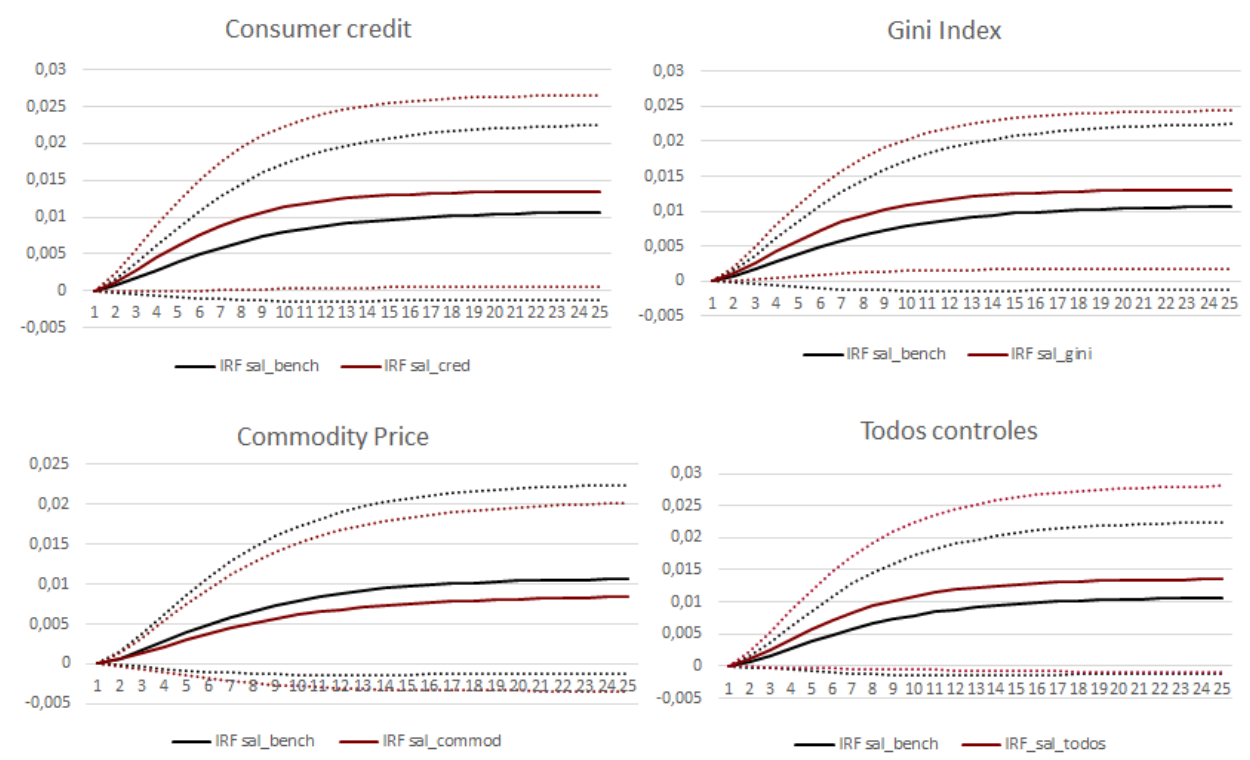

Já nos controles para concessão de crédito às famílias em relação ao PIB e índice de Gini salarial, o intervalo de confiança está todo situado no quadrante positivo por pelo menos 7 e 9 períodos, respectivamente, e seu tracejado é maior que o do benchmark. Estes resultados sugerem que, tirando o efeito do endividamento e da concentração salarial, a tendência profit squeeze de alargamento da parcela salarial a partir de choques de demanda é fortalecida. Quanto ao crédito, tal resultado pode estar relacionado ao efeito concentrador do endividamento. No segundo, a concentração salarial no topo ou os baixos salários na base devem comprometer o poder de barganha do trabalhador médio e, portanto, controlando para este fator, choques de demanda impactariam mais a distribuição funcional a favor dos salários. 
Finalmente, no VAR que inclui os três controles prevalece o efeito fortalecedor da tendência profit squeeze dos VAR de endividamento e índice de Gini sobre o enfraquecedor do preço de commodities. Isto sugere que as altas taxas de endividamento do período e a desconcentração salarial comprometeram, em certa medida, o impacto positivo da demanda aquecida sobre o mercado de trabalho e, consequentemente, sobre a parcela salarial. O impacto do endividamento é esperado pelos encargos pagos sobre ele e por transferir renda aos donos dos bancos no longo prazo. O impacto da desconcentração se deve à relação negativa entre concentração salarial e concentração funcional encontrada empiricamente; a redução no prêmio dos gerentes em relação aos demais trabalhadores esteve provavelmente diminuindo a parcela total de salários na renda.

\subsection{Considerações finais}

O exercício empírico desenvolvido neste capítulo seguiu a estratégia empírica de estudos que buscam identificar a natureza de regimes de demanda de países pelo método VAR. A singularidade deste trabalho foi a inclusão de variáveis exógenas de controle para fatores que estiveram por trás do bom desempenho da economia brasileira nos anos 2000, a dizer o índice de Gini para salários como representante para a distribuição pessoal da renda; a razão concessão de crédito a pessoas físicas PIB para a extensão de endividamento das famílias; e o índice de preço das commodities representando o efeito de economia aberta. Constatou-se tendência profit squeeze na curva distributiva e profit-led na curva de demanda efetiva em todas as estimações.

As estimações sugerem que, de fato, os controles devem alterar o efeito da demanda sobre a distribuição e vice versa. A curva de demanda efetiva se mostrou mais sensível ao efeito de economia aberta via preço de commodities, cujo coeficiente foi significante na estimação a 1\%. Dois efeitos foram encontrados: o primeiro de preços mais altos incrementarem a demanda efetiva e o segundo de tornarem o regime de demanda mais profit-led. Estes resultados estão alinhados às conclusões do modelos neo-Kaleckianos que incluem o efeito de economia aberta; se por um lado altos preços de exportações aumentam a demanda efetiva interna por ser uma importante fonte de demanda, por outro, tirar este efeito deve aumentar a sensibilidade da economia a redistribuições a favor dos salários.

Quanto à distribuição pessoal, cujo coeficiente foi significante a 10\%, a redução na concentração salarial no período surtiu efeito expansionista na demanda efetiva - que pode ser explicado por propensões a poupar diferentes entre assalariados no topo e na base da distribuição - e operou intensificando o caráter profit-led da economia, resultado semelhante a Carvalho e Rezai (2015). Finalmente, o efeito do endividamento das famílias foi o de impulsionar a demanda efetiva - pelo maior consumo dada qualquer parcela salarial - e de praticamente não alterar o caráter do regime de demanda. 
Vale mencionar um último aspecto das estimações da curva de demanda efetiva. A distribuição funcional defasada só é significante na estimação do grau de utilização no VAR base e com significância de 10\%. A inclusão de variáveis exógenas de controle ocasionou que tal significância desaparecesse, o que pode estar sugerindo que a demanda do Brasil no período respondeu mais às extensões analisadas do que à própria distribuição funcional. Este resultado reforça a crítica de variáveis omitidas enviesarem os resultados dos estudos que estimam regimes de demanda.

Quanto à curva distributiva, a redução na concentração salarial reduziu também a parcela de salários na renda, resultado oposto à relação negativa entre prêmio dos gerentes e parcela de salários na renda do modelo teórico do capítulo 2 . A redução no prêmio salarial dos trabalhadores do topo da distribuição, ao reduzir o índice de Gini, estaria reduzindo a parcela total de salários na renda, ao invés de aumentá-la, como preveria o modelo. Por outro lado, a desconcentração salarial verificada no período pareceu enfraquecer o caráter profit squeeze da curva distributiva; controlar para o índice de Gini elevou a resposta dos salários a choques de demanda. O efeito do endividamento das famílias foi na mesma linha: de reduzir a parcela salarial ceteris paribus e de amenizar a tendência profit squeeze da curva distributiva. Este resultado pode ser atribuído ao fluxo de renda de salários para lucros proveniente da rolagem da dívida, ainda que este efeito seja mais provável no longo prazo.

Finalmente, o efeito de economia aberta foi de contrair a parcela salarial ceteris paribus, impacto que pode ser explicado pelo fluxo de lucro proveniente das exportações não distribuídos aos assalariados. Além disso, o efeito de economia aberta tornou a reação dos salários a choques de demanda mais profit squeeze. Este último resultado foi curioso por ser o oposto do que é esperado pela literatura Kaleckiana de economia aberta ( Blecker (2011)). Uma possível explicação é que o choque externo positivo ao injetar renda e demanda na economia brasileira deve ter aquecido o mercado de trabalho, possibilitando maior poder de barganha aos trabalhadores na disputa distributiva. 


\section{Conclusão}

Esta dissertação partiu do arcabouço teórico neo-Kaleckiano e de suas extensões para analisar nos âmbitos teórico e empírico a relação entre demanda agregada, distribuição funcional da renda e distribuição intrasalarial, inspirando-se na trajetória da economia brasileira nos anos 2000. O período entre 2004 e 2010 é marcado por altas taxas de crescimento do produto, redução na concentração dos salários, e reversão na trajetória decrescente da participação dos salários na renda, com algumas outras particularidades, como o aumento do endividamento das famílias e a alta demanda por commodities exportadas pelo país.

O primeiro capítulo revisou o arcabouço teórico neo-Kaleckiano, enfatizando a literatura existente que aborda as extensões teóricas de interesse, discutindo os estudos empíricos na área e expondo as críticas a eles direcionadas. O segundo capítulo desenvolveu um modelo Kaleckiano teórico que aborda relação dinâmica de longo prazo entre distribuição funcional, intrasalarial e o endividamento das famílias. O terceiro capítulo investigou como três fatores por trás do bom desempenho da economia brasileira no período - a distribuição intrasalrial, o endividamento, e o efeito de economia aberta - afetam a relação recíproca entre distribuição funcional e demanda efetiva, medidos respectivamente pela parcela de salários e pelo grau de utilização.

O modelo teórico foi desenvolvido a partir de uma economia com duas classes: pobres, que se endividam para financiar parte de seu consumo; e ricos, formados por gerentes assalariados e capitalistas (donos das firmas e dos bancos), que só consomem parte de sua renda híbrida. A análise de curto prazo do modelo ofereceu resultados similares aos já existentes na literatura que trata do endividamento: a maior predisposição dos bancos a ofertar crédito aumenta a demanda; a concentração intra-salarial contrai a demanda; e o efeito da distribuição funcional está sujeito à contraposição entre os efeitos sobre o investimento e consumo, tradicionais em modelos neo-Kaleckianos.

As contribuições relevantes do modelo foram obtidas na análise de longo prazo. O primeiro resultado foi que a concentração de salários a favor de gerentes eleva a concentração funcional a favor dos lucros, isto é, as tendências à concentração ou desconcentração da renda funcional e pessoal caminham juntas. Este resultado foi obtido combinando hipóteses já existentes na literatura sobre a disputa distributiva no mercado de trabalho (inspirada em Goodwin (1967)), e sobre a produtividade relacionada ao alinhamento dos interesses dos gerentes e capitalistas quanto à renda que recebem (inspirado em Tavani e Vasudevan (2014)).

O segundo resultado foi de que o regime de demanda importa para a classificação 
da economia como inequality ou equality-led quanto aos salários. Se a economia é profitled, então a elevação no prêmio salarial dos gerentes eleva a parcela de lucros, estimula a demanda efetiva, tornando-a também inequality-led. O efeito do endividamento no caso profit-led foi de reforçar a tendência positiva sobre a demanda da concentração salarial ou negativa da desconcentração salarial. Se, por outro lado, é wage-led, a distribuição a favor dos trabalhadores pobres não necessariamente aumenta a demanda efetiva - regime quanto à distribuição salarial pode ser equality ou inequality led. A elevação da dívida de equilíbrio decorrente da melhora distributiva enfraquece o impacto positivo de redistribuições a favor dos trabalhadores (ou o negativo da redistribuição a favor dos ricos). Portanto, em economias profit-led o efeito dívida fortalece o efeito de redistribuições sobre a demanda, e em economias wage-led, o efeito dívida o ameniza.

Este resultado foi decorrente da forma como a equação para variações no endividamento foi modelada. A melhora distributiva, ao possibilitar maior acesso ao crédito, é capaz de estimular a demanda no curto prazo, mas também acarreta estoque da dívida de equilíbrio no longo prazo elevado, o que compromete maior parte da renda dos pobres com seu serviço. Este efeito deve ser um tanto mais depreciativo quanto mais elevadas as taxas de juros bancárias praticadas.

Estes resultados distinguem-se dos encontrados em outros modelos que abordam a relação entre distribuição pessoal e endividamento. A maioria destes modelos (eg Setterfield e Kim (2016), Setterfield, Kim e Rees (2016), Ryoo e Kim (2014), Barba e Pivetti (2009)) busca modelar a relação positiva entre endividamento e concentração observada nos países ricos. O modelo aqui desenvolvido se adequa mais à realidade econômica de países como o Brasil, no qual os baixos níveis de renda de uma parte significativa da população ainda configuram entrave para o acesso ao mercado de crédito. Ao estruturar uma relação dinâmica entre as variáveis distributivas e o endividamento partindo de pressupostos tradicionais da literatura Kaleckiana, o estudo foi capaz de analisar esta relação e discutir seus desdobramentos sobre regimes de demanda profit-led e wage-led.

No âmbito empírico, o objetivo do exercício econométrico foi identificar como fatores geralmente não considerados nas estimações de regimes de demanda afetam a relação entre a distribuição funcional e a demanda efetiva. Foram incluídas variáveis de controle para a distribuição intrasalarial, para o efeito de economia aberta e para o endividamento na estimação de um vetor autoregressivo (VAR), com grau de utilização e parcela de salários.

Os resultados sugeriram que preços de commodities ascendentes, redução na desigualdade salarial e o aumento do endividamento das famílias tiveram efeitos positivos e significantes sobre a demanda efetiva da economia brasileira no período analisada. Além disso, as três variáveis atuaram reforçando a tendência profit-led da economia brasileira no período. 
Um último aspecto relevante do estudo econométrico realizado foi que o coeficiente para o efeito da parcela de salários na renda só se mostrou significante na equação de demanda na estimação sem qualquer controle. A inclusão das três variáveis exógenas dissipou tal efeito. Este resultado sugere que a ausência de controles deve enviesar os resultados dos estudos de regime de demanda existentes e evidencia a necessidade de se considerar particularidades econômicas de cada país para além da distribuição funcional ao se realizar estudos empíricos desta natureza.

Estes resultados contribuem para o debate sobre crescimento "liderado pela demanda" do Brasil nos anos 2000, sua sustentabilidade e que fatores estiveram por trás do bom desempenho econômico. O efeito positivo e significante sobre o grau de utilização de concessões de crédito a famílias e do preço das commodities sugere que estes fatores devem ter contribuído para estimular o consumo e o investimento no período. O efeito negativo da concentração salarial através do índice de Gini para salários sinaliza que a redução da disparidade salarial no período também deve ter contribuído para estimular a demanda. Com a desaceleração econômica recente, entretanto, pode-se questionar a sustentabilidade de tal modelo de crescimento. Por um lado, pode ser problemático que parte significante da demanda do país dependa do mercado internacional. Além disso, deve haver um limite para o qual consumo financiado pelo endividamento não prejudica a estabilidade financeira da economia e não tem efeitos distributivos comprometedores, conforme previsto pelo modelo. Por outro lado, o efeito positivo da distribuição pessoal sugere que políticas macroeconômicas redistributivas podem ainda representar uma oportunidade valiosa para estimular a demanda e conduzir o crescimento econômico, especialmente em meio à crise econômica atual. 


\section{APÊNDICE A - Análise de estabilidade do modelo}

A existência de estabilidade do equilíbrio entre as curvas $\dot{\pi}$ e $\dot{d}$ é verificada através da matriz Jacobiana das derivadas parciais de cada curva de equilíbrio em relação às variáveis endógenas do modelos:

$$
J=\left[\begin{array}{ll}
\frac{\partial \dot{d}}{\partial d} & \frac{\partial \dot{d}}{\partial \pi} \\
\frac{\partial \dot{\pi}}{\partial d} & \frac{\partial \dot{\pi}}{\partial \pi}
\end{array}\right]
$$

Há duas condições para que o equilíbrio seja estável:

1. TR $J<0$;

2. DET $J>0$

Substituindo as derivadas das curvas (2.29) e (2.30) na matriz, tem-se a seguinte configuração, onde os sobreescritos nas variáveis representam sua derivada em relação à variável (por exemplo, $u_{d}$ é a derivada do grau de utilização em relação ao estoque da dívida).

$$
J=\left[\begin{array}{cc}
u_{d} \beta \omega_{p} u-i-g_{0}-u g_{u}-u_{d} d g_{u} & -u\left(\frac{\beta}{1+\phi \alpha}+d \gamma_{r}\right)+u_{\pi}\left(\beta \omega_{p}-d g_{u}^{i}\right) \\
f_{u} u_{d} & f_{u} u_{\pi}-1
\end{array}\right]
$$

A primeira linha da matriz associada às derivadas da curva $\partial \dot{d} / \partial d$ está reescrita abaixo.

$$
\frac{\partial \dot{d}}{\partial d}=u_{d} \beta \omega_{p} u-i-g_{0}-u g_{u}-u_{d} d g_{u}
$$

A derivada do grau de utilização em relação à dívida, $u_{d}$ tem sinal negativo negativo portanto, $\partial \dot{d} / \partial d$ é a soma de quatro termos negativos e um positivo. A intuição por trás dessa derivada é confrontar três efeitos que o aumento do estoque da dívida acarreta sobre sua própria dinâmica: (i) aumentar os encargos pagos pelos pobres - efeito $i$ ; ii) redução do grau de utilização de curto prazo, reduzindo a renda disponível dos pobres, e portanto, o $d$ do período seguinte - efeito $u_{d} \beta \omega_{p} u-$;(iii) mas também deprimir o investimento realizado pela influência da demanda em sua função comportamental, efeito $u g_{u}-u_{d} d g_{u}$. Em outras palavras deve-se avaliar qual variável se reduz mais: $D$ ou $K$ para determinar o efeito final sobre $d$. Para que haja estabilidade, isto é, para se evitar 
trajetória explosiva da dívida, a redução em $D$ deve superar a de $K$. Observe que este cenário é matematicamente mais provável. Da condição (2.4) de curto prazo,

$$
\begin{gathered}
g_{0}>i d\left(s_{\pi}+\beta\right) \\
\leftrightarrow \\
g_{0} \gtrless i d\left(s_{\pi}+\beta\right) \frac{g_{u}^{i}}{\Delta}
\end{gathered}
$$

Mas ainda que $g_{0}$ não supere o termo positivo, $i d\left(s_{\pi}+\beta\right) g_{u}^{i} / \Delta$ há três outros termos negativos em $\partial \dot{d} / \partial d$ que devem garantir matematicamente a estabilidade:

$$
\left|u_{d} \beta \omega_{p} u-i-g_{0}-u g_{u}\right|>\left|u_{d} d g_{u}\right|
$$

Ainda assim, à depender da magnitude dos parâmetros, a trajetória explosiva pode ser verificada, quando a função investimento é hipersensível à demanda. Neste caso, o aumento do estoque da dívida ao reduzir o grau de utilização da economia, deprimiria mais o investimento do que a própria dívida. Apesar de matematicamente factível, a análise conduzida neste modelo se restringe ao caso em que a dívida é estável.

$$
\frac{\partial \dot{d}}{\partial \pi}=-u\left(\frac{\beta}{1+\phi \alpha}+d \gamma_{r}\right)+u_{\pi}\left(\beta \omega_{p}-d g_{u}^{i}\right)
$$

Quanto à $\partial \dot{d} / \partial \pi$ reescrita acima, o aumento da participação dos lucros na renda afeta a variação da dívida de duas formas: pelo efeito distribuição da renda direto, e pelo efeito indireto que $\pi$ surte sobre o grau de utilização.

O primeiro está representado pelo termo negativo $-u\left(\frac{\beta}{1+\phi \alpha}+d u \gamma_{r}\right)$ : a diminuição na parcela de salários na renda reduz a renda disponível dos pobres, por conseguinte, o montante de empréstimo no período seguinte, $D$; e aumenta em algum grau a taxa de acumulação de capital pelo efeito lucratividade, elevando $K$. Estes dois efeitos combinado reduzem $d=D / K$, pois o numerador decresce e o denominador cresce.

A segunda via de influência se dá através do regime de demanda. No caso de uma economia wage led, $u_{\pi}<0$, o termo $u_{\pi} \beta \omega_{p}$ é também negativo: a redução na renda causada pela concentração a favor dos lucros, deprime ainda mais a renda dos pobres, diminuindo o montante a ser tomado emprestado, $D$. O efeito $-u_{\pi} d g_{u}^{i}$, por sua vez, representa o único efeito positivo nesta equação associado à redução na função investimento pelo efeito demanda, redução em $K$. O efeito final sobre $d$ dependerá da magnitude dos parâmetros. Se a redução no investimento for tamanha de forma a superar os outros três efeitos negativos sobre $D$, então $d$ pode aumentar.

No caso de uma economia profit led, há inversão destes sinais. Como $u_{\pi}>0$, $u_{\pi} \beta \omega_{p}>0$, isto é, o efeito demanda afeta positivamente a renda disponível dos pobres, de 
forma a gerar acréscimo em $D$. Por outro lado, o efeito $-u_{\pi} d g_{u}^{i}$ torna-se negativo, isto é, há um efeito indireto proveniente do acréscimo de demanda na função investimento - e como $K$ está no denominador, isto atua reduzindo $\dot{d}$. Note que neste cenário, é mais improvável que $d=D / K$ cresça, uma vez que no regime profit led, no qual $\gamma_{r}$ é elevado, a taxa de acumulação de capital no período seguinte seria reforçada pelos efeitos lucratividade e demanda, dificultando que a variação de $D$ superasse a de $K$.

Portanto, o sinal da derivada $\partial \dot{d} / \partial \pi$ pode ser positivo ou negativo a depender do regime de demanda. Como é caracterizado pela soma de três efeitos negativos com um positivo, parece mais razoável matematicamente que o efeito final seja negativo, especialmente em um regime do tipo profit led.

A análise das derivadas parciais em $\dot{\pi}=0$ é mais direta, uma vez que não se assumiu forma funcional específica para a função que define a meta de lucro dos capitalistas, $\pi_{T}$. Observe que quando o regime de demanda é profit led, a derivada do lócus de pontos em que $\pi$ não varia em relação ao próprio $\pi$, é a soma de dois números negativos, portanto também negativa.

$$
\begin{gathered}
\partial \dot{\pi} / \partial \pi=f_{u} u_{\pi}-1<0 \\
f_{u}<0, \quad u_{\pi}>0, \quad f_{u} u_{\pi}<0
\end{gathered}
$$

No caso wage led, esse resultado se mantém, se os efeitos marginais das derivadas são em módulo menor que a unidade, hipótese já assumida aqui para evitar que trajetória explosiva desta variável.

$$
\begin{gathered}
\partial \dot{\pi} / \partial \pi=f_{u} u_{\pi}-1 \\
\left|f_{u}\right|<1, \quad\left|u_{\pi}\right|<1 \quad \leftrightarrow\left|f_{u} u_{\pi}\right|<1 \\
\partial \dot{\pi} / \partial \pi<0
\end{gathered}
$$

A derivada da curva distributiva em relação ao estoque da dívida, por sua vez, $\partial \dot{\pi} / \partial d=f_{u} u_{d}$ é positiva por ser a multiplicação de dois número negativos. Portanto, a matriz Jacobina possui os seguintes sinais:

$$
J=\left[\begin{array}{ll}
\frac{\partial \dot{d}}{\partial d} & \frac{\partial \dot{d}}{\partial \pi} \\
\frac{\partial \dot{\pi}}{\partial d} & \frac{\partial \dot{\pi}}{\partial \pi}
\end{array}\right]=\left[\begin{array}{cc}
- & +/- \\
+ & -
\end{array}\right]
$$




$$
\begin{gathered}
\text { TR } \quad J=\partial \dot{d} / \partial d+\partial \dot{\pi} / \partial \pi<0 \\
\text { DET } \quad J=\frac{\partial \dot{d}}{\partial d} \frac{\partial \dot{\pi}}{\partial \pi}-\frac{\partial \dot{d}}{\partial \pi} \frac{\partial \dot{\pi}}{\partial d} \gtrless 0
\end{gathered}
$$

Note que se ocorrer o cenário, $\partial \dot{d} / \partial \pi<0$, matematicamente mais provável, o determinante é automaticamente positivo, garantindo a segunda condição de estabilidade:

$$
\begin{gathered}
\frac{\partial \dot{d}}{\partial \pi}<0 \\
\leftrightarrow \\
\operatorname{DET}(J)=\frac{\partial \dot{d}}{\partial d} \frac{\partial \dot{\pi}}{\partial \pi}-\frac{\partial \dot{d}}{\partial \pi} \frac{\partial \dot{\pi}}{\partial d}>0
\end{gathered}
$$

Caso ocorra o cenário contrário, em que $\frac{\partial \dot{d}}{\partial \pi}$ seja positivo, então, a condição abaixo será necessária para garantir que o equilíbrio do modelo se mantenha estável.

$$
\left(u_{d} \beta \omega_{p} u-i-g_{0}-u g_{u}-u_{d} d g_{u}\right)\left(f_{u} u_{\pi}-1\right)+f_{u} u_{d}\left(u\left(\frac{\beta}{1+\phi \alpha}\right)>f_{u} u_{d}\left(u_{\pi}\left(\beta \omega_{p}-d g_{u}^{i}\right)\right.\right.
$$




\section{APÊNDICE B -}

Tabela 6 - Testes de Raiz Unitária

\begin{tabular}{|c|c|c|c|c|c|c|}
\hline \multicolumn{7}{|c|}{$\begin{array}{l}\text { H0: Série possui uma raiz unitária } \\
* \text { se rejeito a } 10 \% .{ }^{* *} \text { se rejeito a } 5 \% .{ }^{* *} \text { se rejeito a } 1 \%\end{array}$} \\
\hline Teste & par_sal_denton_x12 & nuci_tri_x12 & cambio & cred_pib & p_commod & gini_sal \\
\hline $\mathrm{ADF}$ ( constante) & $(-4.327953)^{* * *}$ & $(-3.234472)^{* *}$ & $(-1,227481)$ & 0,738745 & $-0,014638$ & 1,871506 \\
\hline ADF (constante + tendência) & $(-5,019352)^{* * *}$ & $(-3.667370)^{* *}$ & $-1,444333$ & $-1,354968$ & $-2,489587$ & $-0,672059$ \\
\hline DF GLS (constante) & $(-1,976528)^{* *}$ & $(-3.032598)^{* * *}$ & 0,304509 & 0,594156 & 0,249665 & 0.147876 \\
\hline Df GLS (constante + tendência) & $(-2,835549)^{*}$ & $(-3.702252)^{* * *}$ & $-1,506997$ & $-2,040464$ & $-1,888693$ & -0.836717 \\
\hline Conclusão & $\mathrm{I}(0)$ & $\mathrm{I}(0)$ & $\mathrm{I}(1)$ & $\mathrm{I}(1)$ & $\mathrm{I}(1)$ & $\mathrm{I}(1)$ \\
\hline
\end{tabular}

Tabela 7 - Granger Causality Test

"Exogenous" Variables in level

Null hypothesis: Variable (column) does not Granger-cause variable (line):

$*$ if rejection of h0 at $10 \%, * *$ if rejection at $5 \%$ and $* * *$ at $1 \%$

\begin{tabular}{lllllll}
\hline & nuci_tri_12 & par_sal_denton_x12 & cred_pib & p_commod & gini_sal & cambio \\
\hline par_sal_denton_x12 & & & 0.6933 & 0.8830 & 0.7217 & $0.0224^{* *}$ \\
nuci_tri_12 & & & 0.1422 & 0.9461 & 0.3426 & 0.5031 \\
cred_pib & 0.2217 & 0.6933 & & & \\
p_commod & $0.0002^{* * *}$ & 0.2917 & & & \\
gini_sal & $0.0955^{*}$ & 0.7609 & & & \\
cambio & $0.0725^{*}$ & $0.0002^{* * *}$ & & & \\
par_ser_x12 & 0.2378 & $0.0224^{* *}$ & & & \\
\hline \hline
\end{tabular}

"Exogenous"variables differenced

Null hypothesis: Variable (column) does not Granger-cause variable (line):

$*$ if $\mathrm{I}^{*}$ if rejection of $\mathrm{h} 0$ at $10 \%,{ }^{* *}$ if rejection at $5 \%$ and $* * *$ at $1 \%$

\begin{tabular}{lllllll}
\hline & nuci_tri_12 & par_sal_denton_x12 & dcred_pib & dp_commod & dgini_sal & dcambio \\
\hline par_sal_denton_x12 & 0.2644 & & 0.801 & 0.4531 & 0.4511 & $0.0357^{* *}$ \\
nuci_tri_12 & & 0.2285 & $0.0549^{* *}$ & 0.2772 & 0.1647 & 0.3609 \\
dcred_pib & 0.3901 & 0.9839 & & & \\
dp_commod & $7 . E-05^{* * *}$ & 0.3205 & & & \\
dgini_sal & 0.414 & 0.6845 & & & \\
dcambio & $0.0654^{*}$ & $0.0217^{* *}$ & & & &
\end{tabular}




\section{Referências}

AMADEO, E. J. The role of capacity utilization in long-period analysis. Political Economy, v. 2, n. 2, p. 147-185, 1986. Citado 2 vezes nas páginas 17 e 18.

ARAúJO, E.; GALA, P. Regimes de crescimento econômico no brasil: evidências empíricas e implicações de política. estudos avançados, SciELO Brasil, v. 26, n. 75, p. 41-56, 2012. Citado na página 33.

ARNIM, R. von; TAVANI, D.; CARVALHO, L. Barbosa de. Globalization as coordination failure: a Keynesian perspective. [S.l.], 2012. Citado na página 23.

ASIMAKOPULOS, A. A kaleckian theory of income distribution. Canadian Journal of Economics, JSTOR, p. 313-333, 1975. Citado na página 17.

AVRITZER, J. D.; FREITAS, F. N.; BRAGA, J. de M. Crescimento e a distribuição funcional da renda no brasil entre 1952 e 2011. ANPEC, 2014. Citado 2 vezes nas páginas 33 e 34 .

BARBA, A.; PIVETTI, M. Rising household debt: Its causes and macroeconomic implications - a long-period analysis. Cambridge Journal of Economics, CPES, v. 33, n. 1, p. 113-137, 2009. Citado 8 vezes nas páginas 14, 19, 27, 29, 37, 42, 56 e 85.

BARBOSA-FILHO, N. H.; TAYLOR, L. Distributive and demand cycles in the us economy - a structuralist goodwin model. Metroeconomica, Wiley Online Library, v. 57, n. 3, p. 389-411, 2006. Citado 6 vezes nas páginas 14, 20, 32, 73, 75 e 77.

BASTOS, E. K. X. Distribuição funcional da renda no Brasil: estimativas anuais e construção de uma série trimestral. [S.l.], 2012. Citado 3 vezes nas páginas 67, 68 e 70.

BHADURI, A.; MARGLIN, S. Unemployment and the real wage: the economic basis for contesting political ideologies. Cambridge journal of Economics, JSTOR, v. 14, n. 4, p. 375-393, 1990. Citado 4 vezes nas páginas 14, 17, 18 e 27.

BLANCHARD, O. J.; QUAH, D. The dynamic effects of aggregate demand and supply disturbances. [S.l.]: National Bureau of Economic Research Cambridge, Mass., USA, 1988. Citado na página 73.

BLECKER, R. A. Open economy models of distribution and growth. A Modern Guide to Keynesian Macroeconomics and Economic Policies, Edward Elgar Cheltenham, UK, p. 215-39, 2011. Citado 4 vezes nas páginas 14, 19, 23 e 83.

BLECKER, R. A. et al. Wage-led versus profit-led demand regimes: The long and the short of it. Eastern Economic Association, New York, NY. Available at: http://nw08. american. edu/ blecker/research/Blecker_LRvsSR_EEA2015. pdf, 2015. Citado 3 vezes nas páginas 34, 35 e 59.

BOWLES, S.; BOYER, R. Wages, aggregate demand, and employment in an open economy: an empirical investigation. Macroeconomic policy after the conservative era, Cambridge University Press, Cambridge, p. 143-71, 1995. Citado 3 vezes nas páginas 14,20 e 32. 
BRUNO, M. Crescimento econômico, mudanças estruturais e distribuição: as transformações do regime de acumulação no brasil. Francia, mimeo, 2005. Citado na página 33.

CARVALHO, F. J. C. de. Financial liberalization in brazil and argentina. In: Financial Liberalization and Economic Performance in Emerging Countries. [S.l.]: Springer, 2008. p. 121-141. Citado na página 33.

CARVALHO, L.; REZAI, A. Personal income inequality and aggregate demand. Cambridge Journal of Economics, CPES, p. beu085, 2015. Citado 8 vezes nas páginas $14,19,24,26,58,61,63$ e 82.

CARVALHO, L.; RUGITSKY, F. Growth and distribution in Brazil in the 21st century: revisiting the wage-led versus profit-led debate. [S.l.], 2015. Citado 6 vezes nas páginas $15,37,59,61,62$ e 65 .

CHOW, G. C.; LIN, A.-l. Best linear unbiased interpolation, distribution, and extrapolation of time series by related series. The review of Economics and Statistics, JSTOR, p. 372-375, 1971. Citado na página 68.

CONSIDERA, C.; PESSOA, S. A distribuição funcional da renda no brasil: 1959-2009. Rio de Janeiro: FGV/IBRE, 2011. Citado 2 vezes nas páginas 66 e 67.

CYNAMON, B. Z.; FAZZARI, S. M. Inequality and household finance during the consumer age. [S.1.], 2013. Citado 4 vezes nas páginas 26, 27, 36 e 37.

DAGUM, E. B.; CHOLETTE, P. A. Benchmarking, temporal distribution, and reconciliation methods for time series. [S.l.]: Springer Science \& Business Media, 2006. Citado na página 68.

DENTON, F. T. Adjustment of monthly or quarterly series to annual totals: an approach based on quadratic minimization. Journal of the American Statistical Association, Taylor \& Francis Group, v. 66, n. 333, p. 99-102, 1971. Citado 3 vezes nas páginas 68, 69 e 70.

DIALLO, M. B. et al. Reconsidering the dynamic interaction between real wages and macroeconomic activity. Research in World Economy, Sciedu Press, v. 2, n. 1, p. 77, 2011. Citado na página 32.

DUMÉNIL, G.; LÉVY, D. Capital resurgent: Roots of the neoliberal revolution. [S.l.]: Harvard University Press, 2004. Citado na página 25.

DUTT, A. K. Stagnation, income distribution and monopoly power. Cambridge journal of Economics, JSTOR, v. 8, n. 1, p. 25-40, 1984. Citado 4 vezes nas páginas 14, 17, 18 e 41 .

DUTT, A. K. 'unproductive'sectors and economic growth: A theoretical analysis. Review of Political Economy, Taylor \& Francis, v. 4, n. 2, p. 178-202, 1992. Citado 4 vezes nas páginas 14, 19, 24 e 29.

DUTT, A. K. Maturity, stagnation and consumer debt: a steindlian approach.

Metroeconomica, Wiley Online Library, v. 57, n. 3, p. 339-364, 2006. Citado 11 vezes nas páginas 14, 19, 26, 27, 29, 30, 41, 42, 45, 64 e 79. 
ENGLE, R. F.; HENDRY, D. F.; RICHARD, J.-F. Exogeneity. Econometrica: Journal of the Econometric Society, JSTOR, p. 277-304, 1983. Citado na página 73.

FAGUNDES, L. Dinâmica do consumo, do investimento e o supermultiplicador: uma contribuição á teoria do cresciemnto liderada pela demanda. [S.1.], 2017. Citado na página 30.

FERNANDEZ, R. B. A methodological note on the estimation of time series. The Review of Economics and Statistics, JSTOR, v. 63, n. 3, p. 471-476, 1981. Citado na página 68.

FRANKE, R.; FLASCHEL, P.; PROANO, C. R. Wage-price dynamics and income distribution in a semi-structural keynes-goodwin model. Structural Change and Economic Dynamics, Elsevier, v. 17, n. 4, p. 452-465, 2006. Citado na página 32.

GODLEY, W.; LAVOIE, M. Monetary economics: an integrated approach to credit, money, income, production and wealth. [S.l.]: Springer, 2012. Citado na página 30.

GOLLIN, D. Getting income shares right. Journal of political Economy, JSTOR, v. 110, n. 2, p. 458-474, 2002. Citado na página 66.

GOODWIN, R. M. A growth cycle model. Socialism, Capitalism, and Economic Growth, Cambridge University Press, Cambridge, 1967. Citado 9 vezes nas páginas 20, 21, 25, $32,49,52,55,75$ e 84 .

GOODWIN, R. M. A growth cycle. In: Essays in Economic Dynamics. [S.1.]: Springer, 1982. p. 165-170. Citado na página 51.

HEIN, E. The macroeconomics of finance-dominated capitalism and its crisis. [S.1.]: Edward Elgar Publishing, 2012. Citado 2 vezes nas páginas 26 e 30.

HEIN, E.; VOGEL, L. Distribution and growth reconsidered: empirical results for six oecd countries. Cambridge journal of Economics, CPES, v. 32, n. 3, p. 479-511, 2008. Citado 2 vezes nas páginas 32 e 33 .

HOFFMANN, R. Transferências de renda e desigualdade no brasil. Instituto de Pesquisa Econômica Aplicada (Ipea), 2013. Citado na página 62.

KALDOR, N. Alternative theories of distribution. The Review of Economic Studies, JSTOR, v. 23, n. 2, p. 83-100, 1955. Citado na página 14.

KALECKI, M. A theory of profits. The Economic Journal, JSTOR, v. 52, n. 206/207, p. 258-267, 1942. Citado 2 vezes nas páginas 13 e 17.

KAPELLER, J.; SCHÜTZ, B. Conspicuous consumption, inequality and debt: The nature of consumption-driven profit-led regimes. Metroeconomica, Wiley Online Library, v. 66, n. 1, p. 51-70, 2015. Citado na página 27.

KEYNES, J. M. The general theory of employment. The quarterly journal of economics, Oxford University Press, v. 51, n. 2, p. 209-223, 1937. Citado na página 13.

KIEFER, D.; RADA, C. Profit maximising goes global: the race to the bottom. Cambridge Journal of Economics, CPES, v. 39, n. 5, p. 1333-1350, 2015. Citado na página 32. 
LAVOIE, M. Unproductive outlays and capital accumulation with target-return pricing. Review of Social Economy, Taylor \& Francis, v. 54, n. 3, p. 303-322, 1996 . Citado 2 vezes nas páginas 19 e 24 .

LAVOIE, M. Post-Keynesian economics: new foundations. [S.l.]: Edward Elgar Publishing, 2014. Citado 3 vezes nas páginas 14, 17 e 38.

LAVOIE, M.; STOCKHAMMER, E. Wage-led growth: concept, theories and policies. project report for the project "new perspectives on wages and economic growth: The potentials of wage-led growth". International Labour Office, Geneva, 2012. Citado 3 vezes nas páginas 14, 19 e 23.

LITTERMAN, R. B. A random walk, markov model for the distribution of time series. Journal of Business \& Economic Statistics, Taylor \& Francis, v. 1, n. 2, p. 169-173, 1983. Citado na página 68.

LUSTIG, N.; LOPEZ-CALVA, L. F.; ORTIZ-JUAREZ, E. Declining inequality in latin america in the 2000s: the cases of argentina, brazil, and mexico. World Development, Elsevier, v. 44, p. 129-141, 2013. Citado na página 14.

LUTKEPOHL, H.; KRATZIG, M. Applied time series econometrics. [S.l.]: Cambridge university press, 2004. Citado na página 73.

MARQUETTI, A.; PORSSE, M. d. C. S. Patterns of technical progress in the brazilian economy, 1952-2008. CEPAL Review, 2014. Citado na página 65.

MEDEIROS, M.; SOUZA, P. H.; CASTRO, F. A. d. O topo da distribuição de renda no brasil: Primeiras estimativas com dados tributários e comparação com pesquisas domiciliares, 2006-2012 (top incomes in brazil: First estimates with tax data and comparison with survey data, 2006-2012). DADOS-Revista de Ciências Sociais, Rio de Janeiro, v. 58, n. 1, 2015. Citado 2 vezes nas páginas 62 e 63.

MOHUN, S. Unproductive labor in the us economy 1964-2010 1. Review of Radical Political Economics, SAGE Publications Sage CA: Los Angeles, CA, v. 46, n. 3, p. 355-379, 2014. Citado na página 25.

NAASTEPAD, C.; STORM, S. Oecd demand regimes (1960-2000). Journal of Post Keynesian Economics, Taylor \& Francis, v. 29, n. 2, p. 211-246, 2006. Citado 3 vezes nas páginas 20, 32 e 75 .

NIKIFOROS, M. Distribution-led growth in the long run. Levy Economics Institute, Working Papers Series, n. 814, 2014. Citado 2 vezes nas páginas 34 e 58.

NIKIFOROS, M.; FOLEY, D. K. Distribution and capacity utilization: conceptual issues and empirical evidence. Metroeconomica, Wiley Online Library, v. 63, n. 1, p. 200-229, 2012. Citado na página 34.

ONARAN, O.; GALANIS, G. Is aggregate demand wage-led or profit-led. National and global effects. ILO Conditions of Work and Employment Series, n. 31, 2012. Citado 4 vezes nas páginas 14, 20, 32 e 58.

PALLEY, T. Post Keynesian economics: debt, distribution and the macro economy. [S.1.]: Springer, 1996. Citado na página 30. 
PALLEY, T. I. A neo-kaleckian-goodwin model of capitalist economic growth: monopoly power, managerial pay and labour market conflict. Cambridge Journal of Economics, CPES, p. bet001, 2013. Citado 4 vezes nas páginas 24, 25, 28 e 49.

PALLEY, T. I. Rethinking wage vs. profit-led growth theory with implications for policy analysis. [S.l.], 2014. Citado 4 vezes nas páginas 26, 34, 58 e 63.

PALLEY, T. I. The middle class in macroeconomics and growth theory: a three-class neo-kaleckian-goodwin model. Cambridge Journal of Economics, CPES, v. 39, n. 1, p. 221-243, 2015. Citado na página 37.

PALLEY, T. I. et al. Inside debt and economic growth: a neo-kaleckian analysis. Chapters, Edward Elgar, 2010. Citado 2 vezes nas páginas 20 e 26.

PEREIRA, L. C. B. Globalization and competition: why some emergent countries succeed while others fall behind. [S.l.]: Cambridge University Press, 2010. Citado na página 33.

PIKETTY, T. Capital in the twenty-first century. Belknap Press of Harvard University Press Cambridge, MA, 2014. Citado 4 vezes nas páginas 13, 24, 36 e 37.

REZAI, A. et al. The political economy implications of general equilibrium analysis in open economy macro models. Department of Economics/NSSR Working Paper, Citeseer, v. 11, 2011. Citado 2 vezes nas páginas 19 e 23.

ROWTHORN, B. Demand, real wages and economic growth. [S.1.]: North East London Polytechnic, 1981. Citado 4 vezes nas páginas 14, 17, 18 e 41.

RUGITSKY, F. Milagre, miragem, antimilagre: A economia política dos governos lula e as raízes da crise atual. Rev. Fevereiro, v. 9, 2016. Citado na página 63.

RYOO, S.; KIM, Y. K. Income distribution, consumer debt and keeping up with the joneses. Metroeconomica, Wiley Online Library, v. 65, n. 4, p. 585-618, 2014. Citado 8 vezes nas páginas 27, 28, 29, 30, 36, 42, 56 e 85.

SANTOS, C. D. et al. Revisitando a dinâmica trimestral do investimento no brasil: 1996-2012. Texto para discussao IE-UFRJ, n. 05, 2015. Citado 4 vezes nas páginas 60, 61,63 e 64.

SAX, C.; STEINER, P. Temporal disaggregation of time series. 2013. Citado na página 68.

SCHETTINI, B. P. et al. New empirical evidence on the quarterly dynamics of brazilian aggregate household consumption from 1995 to 2009. Economia e Sociedade, SciELO Brasil, v. 21, n. 3, p. 607-641, 2012. Citado na página 64.

SCHODER, C. et al. Estimating Keynesian models of business fluctuations using Bayesian Maximum Likelihood. [S.1.], 2016. Citado 3 vezes nas páginas 34, 58 e 59.

SERRANO, F.; SUMMA, R. A desaceleração rudimentar da economia brasileira desde 2011. OIKOS (Rio de Janeiro), v. 11, n. 2, 2012. Citado 4 vezes nas páginas 15, 37, 60 e 62 . 
SETTERFIELD, M. Rising income inequality, increased household indebtedness, and post-keynesian macrodynamics. Increased Household Indebtedness, and Post-Keynesian Macrodynamics (November 3, 2014), 2014. Citado na página 56.

SETTERFIELD, M.; KIM, Y. K. Debt servicing, aggregate consumption, and growth. Structural Change and Economic Dynamics, Elsevier, v. 36, p. 22-33, 2016. Citado 12 vezes nas páginas $14,26,28,30,36,37,39,42,43,56,64$ e 85.

SETTERFIELD, M.; KIM, Y. K.; REES, J. Inequality, debt servicing and the sustainability of steady state growth. Review of Political Economy, Taylor \& Francis, v. 28, n. 1, p. 45-63, 2016. Citado 9 vezes nas páginas 19, 26, 28, 29, 30, 39, 42, 43 e 85.

SIMS, C. A. Macroeconomics and reality. Econometrica: Journal of the Econometric Society, JSTOR, p. 1-48, 1980. Citado na página 73.

SKOTT, P. Notes on wage-led versus profit-led growth. Workshop on Analytical Political Economy, Sendai, Japan, p. 24-25, 2015. Citado 5 vezes nas páginas 31, 34, 35, 58 e 59.

STEINDL, J. Maturity and stagnation in American capitalism. [S.l.]: NYU Press, 1952. Citado na página 17.

STOCKHAMMER, E.; EDERER, S. Demand effects of the falling wage share in austria. Empirica, Springer, v. 35, n. 5, p. 481-502, 2008. Citado na página 20.

STOCKHAMMER, E.; ONARAN, Ö. Rethinking wage policy in the face of the euro crisis. implications of the wage-led demand regime. International Review of Applied Economics, Taylor \& Francis, v. 26, n. 2, p. 191-203, 2012. Citado na página 32.

STOCKHAMMER ENGELBERT, O. O. E.; STEFAN. Functional income distribution and aggregate demand in the euro area. Cambridge journal of Economics, CPES, v. 33, n. 1, p. 139-159, 2009. Citado 3 vezes nas páginas 14, 20 e 32.

TAVANI, D.; VASUDEVAN, R. Capitalists, workers, and managers: Wage inequality and effective demand. Structural Change and Economic Dynamics, Elsevier, v. 30, p. 120-131, 2014. Citado 9 vezes nas páginas 14, 19, 24, 25, 48, 49, 51, 53 e 84.

TAYLOR, L. A stagnationist model of economic growth. Cambridge Journal of Economics, JSTOR, v. 9, n. 4, p. 383-403, 1985. Citado 4 vezes nas páginas 14, 17, 18 e 41 .

TAYLOR, L. Reconstructing macroeconomics: Structuralist proposals and critiques of the mainstream. [S.l.]: Harvard University Press, 2009. Citado 2 vezes nas páginas 21 e 75.

TOMIO, B. T. Understanding the Brazilian demand regime: A Kaleckian approach. [S.1.], 2016. Citado na página 33.

VEBLEN, T. A teoria da classe ociosa: um estudo econômico das instituições. [S.l.]: Nova Cultural, 1988. Citado na página 27. 